\title{
U.S. Department of Energy Zero Energy Ready Home Implementation
}

E. VonThoma and G. Mosiman NorthernSTAR 


\section{NOTICE}

This report was prepared as an account of work sponsored by an agency of the United States government. Neither the United States government nor any agency thereof, nor any of their employees, subcontractors, or affiliated partners makes any warranty, express or implied, or assumes any legal liability or responsibility for the accuracy, completeness, or usefulness of any information, apparatus, product, or process disclosed, or represents that its use would not infringe privately owned rights. Reference herein to any specific commercial product, process, or service by trade name, trademark, manufacturer, or otherwise does not necessarily constitute or imply its endorsement, recommendation, or favoring by the United States government or any agency thereof. The views and opinions of authors expressed herein do not necessarily state or reflect those of the United States government or any agency thereof.

This report is available at no cost from the National Renewable Energy Laboratory (NREL) at www.nrel.gov/publications.

Available electronically at SciTech Connect http:/www.osti.gov/scitech

Available for a processing fee to U.S. Department of Energy and its contractors, in paper, from:

U.S. Department of Energy

Office of Scientific and Technical Information

P.O. Box 62

Oak Ridge, TN 37831-0062

OSTI http://www.osti.gov

Phone: 865.576.8401

Fax: 865.576.5728

Email: reports@osti.gov

Available for sale to the public, in paper, from:

U.S. Department of Commerce

National Technical Information Service

5301 Shawnee Road

Alexandria, VA 22312

NTIS http://www.ntis.gov

Phone: 800.553 .6847 or 703.605 .6000

Fax: 703.605.6900

Email: orders@ntis.gov 


\section{U.S. Department of Energy Zero Energy Ready Home Implementation}

Prepared for:

The National Renewable Energy Laboratory

On behalf of the U.S. Department of Energy’s Building America Program

Office of Energy Efficiency and Renewable Energy

15013 Denver West Parkway

Golden, CO 80401

NREL Contract No. DE-AC36-08GO28308

Prepared by:

E. VonThoma and G. Mosiman

NorthernSTAR Building America Partnership

University of Minnesota

2400 Folwell Avenue

St. Paul, MN 55108

NREL Technical Monitor: Stacey Rothgeb

Prepared under Subcontract No. KNDJ-0-403388-00

July 2017 
The work presented in this report does not represent performance of any product relative to regulated minimum efficiency requirements.

The laboratory and/or field sites used for this work are not certified rating test facilities. The conditions and methods under which products were characterized for this work differ from standard rating conditions, as described.

Because the methods and conditions differ, the reported results are not comparable to rated product performance and should only be used to estimate performance under the measured conditions. 


\section{Contents}

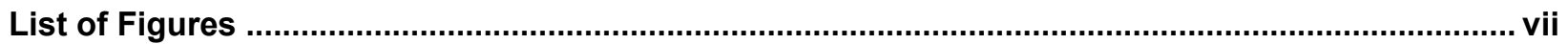

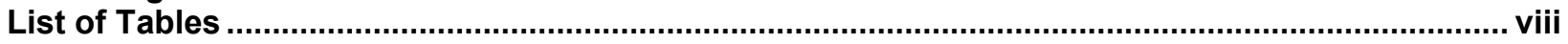

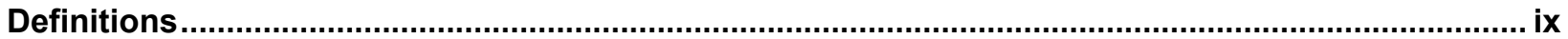

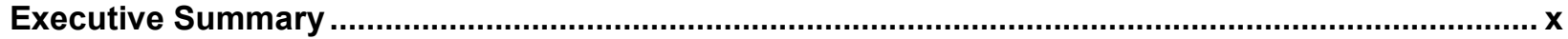

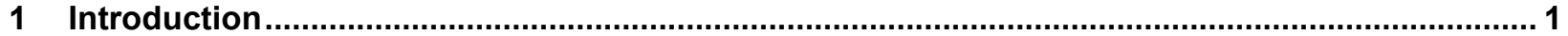

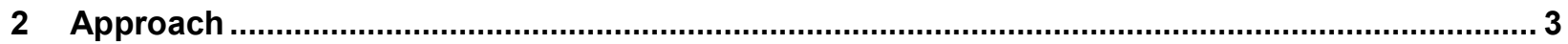

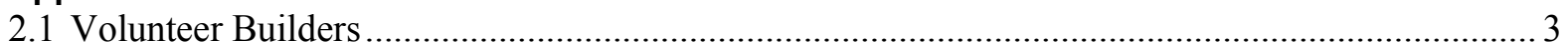

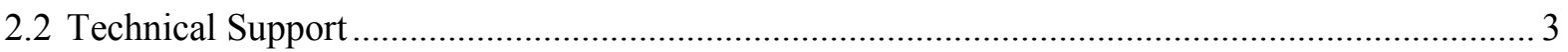

2.2.1 Technical Support from the University of Minnesota ............................................... 3

2.2.2 Technical Support from HERS Raters ........................................................................ 4

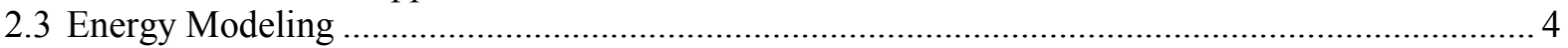

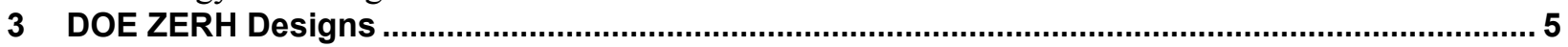

3.1 Amaris Custom Homes: Saint Paul, Minnesota, Model Home Project …...................................... 5

3.1.1 Basic Project Information .................................................................................. 5

3.1.2 Technical Characteristics of Typical Construction Practices and DOE ZERH Solutions .. 7

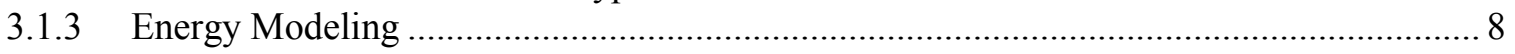

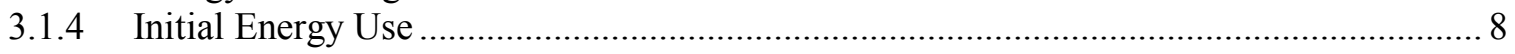

3.2 Amaris Custom Homes: Bloomington, Minnesota, Project........................................................ 11

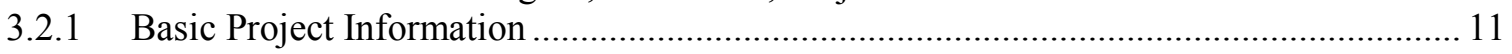

3.2.2 Technical Characteristics of Typical Construction Practices and DOE ZERH Solutions 13

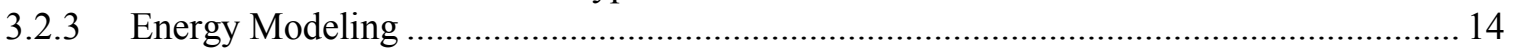

3.3 Amaris Custom Homes: Vadnais Heights, Minnesota, Project .............................................. 15

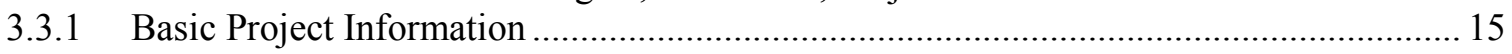

3.3.2 Technical Characteristics of Typical Construction Practices and DOE ZERH Solutions 17

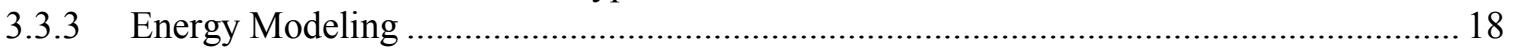

3.4 Amaris Custom Homes: Apple Valley, Minnesota, Project …................................................... 19

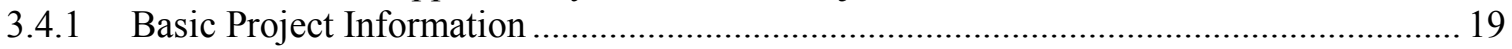

3.4.2 Technical Characteristics of Typical Construction Practices and DOE ZERH Solutions 21

3.4.3 Energy Modeling .................................................................................................. 22

3.5 Amaris Custom Homes: White Bear Township, Minnesota, Project............................................ 23

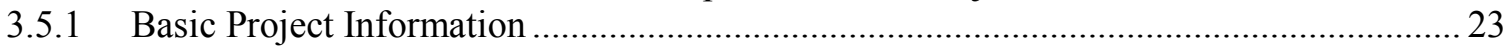

3.5.2 Technical Characteristics of Typical Construction Practices and DOE ZERH Solutions 25

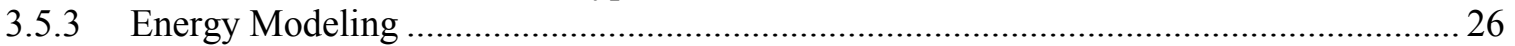

3.6 Amaris Custom Homes: Mound, Minnesota, Project ……........................................................... 27

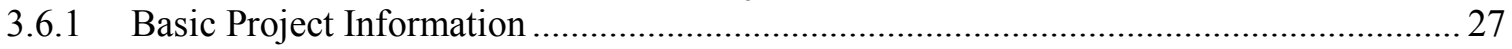

3.6.2 Technical Characteristics of Typical Construction Practices and DOE ZERH Solutions 28

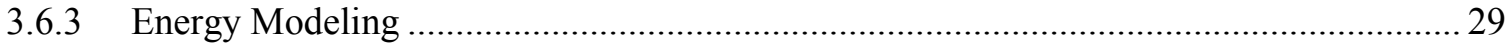

3.7 Amaris Custom Homes: Stillwater, Minnesota, Project ….......................................................... 30

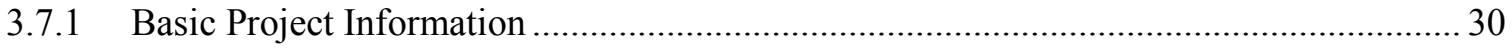

3.7.2 Technical Characteristics of Typical Construction Practices and DOE ZERH Solutions 31

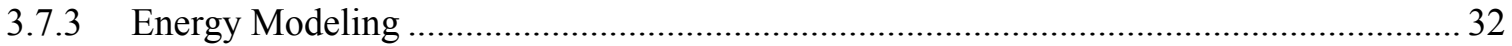

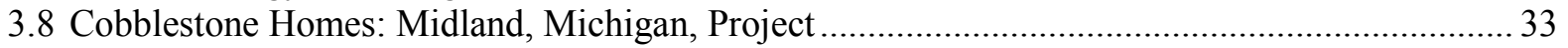

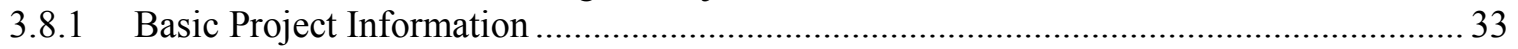

3.8.2 Technical Characteristics of Typical Construction Practices and DOE ZERH Solutions 33

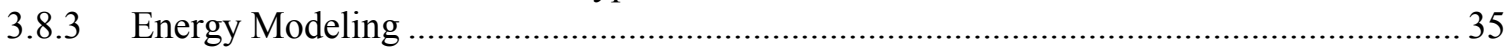

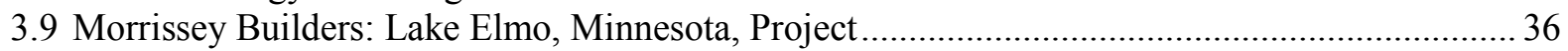

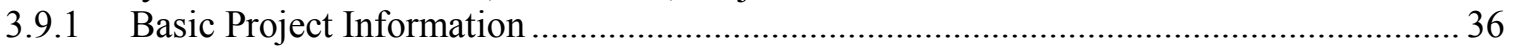

3.9.2 Technical Characteristics of Typical Construction Practices and DOE ZERH Solutions 37

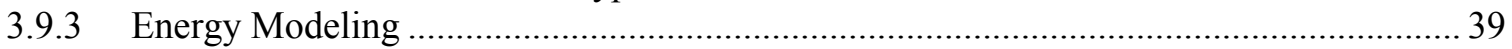

U.10 Urban Homeworks: North Minneapolis, Minnesota, Project ….................................... 40 
3.10.1 Basic Project Information....

3.10.2 Technical Characteristics of Typical Construction Practices and DOE ZERH Solutions 41

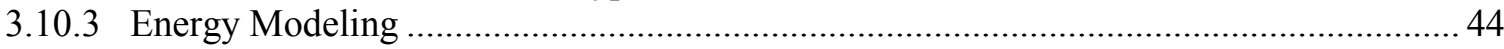

4 Analysis.

4.1 Barriers 45

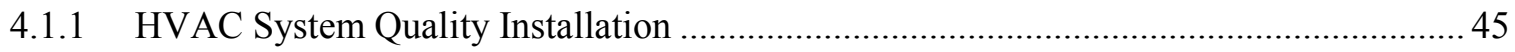

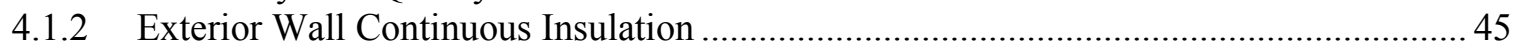

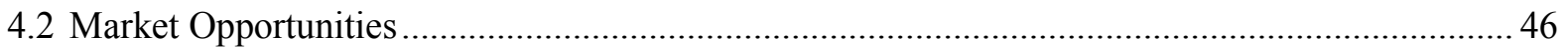

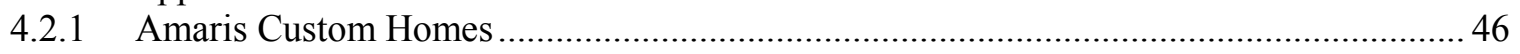

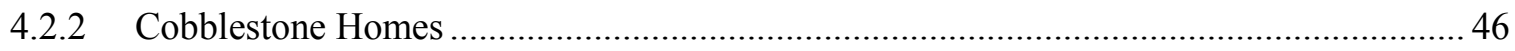

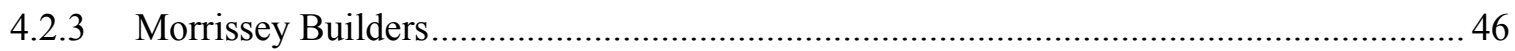

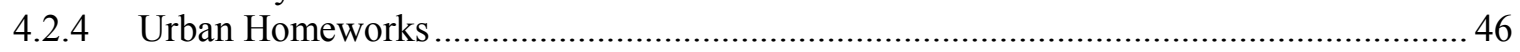

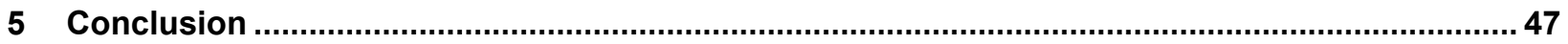

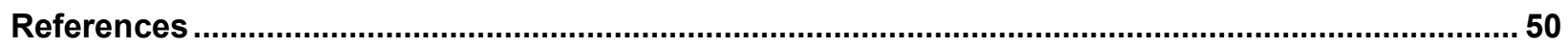

Appendix A: Amaris Custom Homes-St. Paul, Minnesota, Project HERS Reports and

Challenge Home Certification

\section{0}

Appendix B: Amaris Custom Homes-St. Paul, Minnesota Project BEopt Input

Appendix C: Amaris Custom Homes-Bloomington, Minnesota, Project HERS Reports .................57

Appendix D: Amaris Custom Homes-Bloomington, Minnesota, Project BEopt Inputs ................. 59

Appendix E: Amaris Custom Homes-Vadnais Heights, Minnesota, Project HERS Reports and

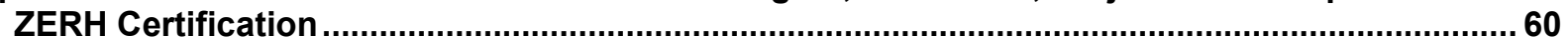

Appendix F: Amaris Custom Homes-Vadnais Heights, Minnesota, Project BEopt Inputs ............... 65

Appendix G: Amaris Custom Homes-Apple Valley, Minnesota, Project HERS Reports and

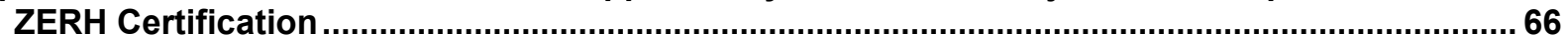

Appendix H: Amaris Custom Homes-Apple Valley, Minnesota, Project BEopt Inputs ................. 71

Appendix I: Amaris Custom Homes-White Bear Township, Minnesota, Project HERS Reports ... 72 Appendix J: Amaris Custom Homes-White Bear Township, Minnesota, Project BEopt Inputs..... 74 Appendix K: Amaris Custom Homes-Mound, Minnesota, Project HERS Reports............................75

Appendix L: Amaris Custom Homes-Mound, Minnesota, Project BEopt Inputs ............................. 77

Appendix M: Amaris Custom Homes_Stillwater, Minnesota, Project HERS Reports .....................78

Appendix N: Amaris Custom Homes-Stillwater, Minnesota, Project BEopt Inputs......................... 80

Appendix O: Cobblestone Homes-Midland, Michigan, Project HERS Reports and ZERH

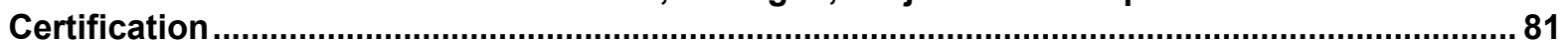

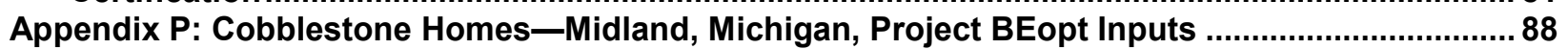

Appendix Q: Morrissey Builders—Lake Elmo, Minnesota, Project Preliminary HERS Reports ....... 89

Appendix R: Morrissey Builders_Lake Elmo, Minnesota, Project BEopt Inputs ............................. 91

Appendix S: Urban Homeworks—North Minneapolis, Minnesota, Project Preliminary HERS

Reports ........................................................................................................................................ 92

Appendix T: Urban Homeworks—North Minneapolis, Minnesota, Project BEopt Inputs ................ 94 


\section{List of Figures}

Figure 1. Amaris Custom Homes: Front elevation of the St. Paul, Minnesota, project ...................... 5 Figure 2. Amaris Custom Homes: Rear elevation of the St. Paul, Minnesota, project ........................ 6 Figure 3. Amaris Custom Homes: Energy modeling results for the St. Paul, Minnesota, project ..... 8 Figure 4. Amaris Custom Homes: Actual compared to modeled annual energy use for the St. Paul, Minnesota, project.

Figure 5. Amaris Custom Homes: Year 1 actual monthly energy use for the St. Paul, Minnesota, project.

Figure 6. Amaris Custom Homes: Year 2 actual monthly energy use for the St. Paul, Minnesota,

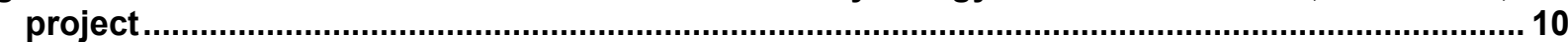

Figure 7. Amaris Custom Homes: Modeled monthly energy use for the St. Paul, Minnesota, project10

Figure 8. Amaris Custom Homes: Front elevation of the Bloomington, Minnesota, project .............11

Figure 9. Amaris Custom Homes: Interior of the Bloomington, Minnesota, project ........................ 12

Figure 10. Amaris Custom Homes: Energy modeling results for the Bloomington, Minnesota, project

Figure 11. Amaris Custom Homes: Front elevation of the Vadnais Heights, Minnesota, project .... 15

Figure 12. Amaris Custom Homes: Rear elevation with solar panels of the Vadnais Heights, Minnesota, project.............................................................................................................. 16

Figure 13. Amaris Custom Homes: Energy modeling results for the Vadnais Heights, Minnesota, project

Figure 14. Amaris Custom Homes: Front elevation of the Apple Valley, Minnesota, project...........19

Figure 15. Amaris Custom Homes: Roof with solar panels of the Apple Valley, Minnesota, project20

Figure 16. Amaris Custom Homes: Energy modeling results for the Apple Valley, Minnesota, project.

Figure 17. Amaris Custom Homes: Front elevation of the White Bear Township, Minnesota, project23

Figure 18. Amaris Custom Homes: Spray foam walls and energy heel truss of the White Bear Township, Minnesota, project

Figure 19. Amaris Custom Homes: Energy modeling results for the White Bear Township, Minnesota, project.

Figure 20. Amaris Custom Homes: Advanced frame wall with spray foam insulation of the Mound,

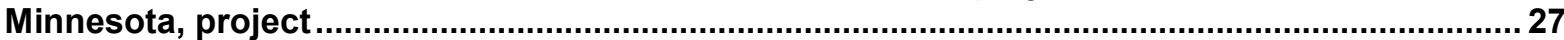

Figure 21. Amaris Custom Homes: Energy modeling results for the Mound, Minnesota, project... 29 Figure 22. Amaris Custom Homes: Front elevation of the Stillwater, Minnesota, project ................ 30 Figure 23. Amaris Custom Homes: Energy modeling results for the Stillwater, Minnesota, project32 Figure 24. Cobblestone Homes: Front elevation of the Midland, Michigan, project......................... 34

Figure 25. Pat Huelman from the NorthernSTAR Building America team at the Cobblestone Innovation event

Figure 26. Cobblestone Homes: Energy modeling results for the Midland, Michigan, project ........ 35 Figure 27. Morrissey Builders: Solar panel installation of the Lake Elmo, Minnesota, project........ 36 Figure 28. Morrissey Builders: Exterior wall assembly of the Lake Elmo, Minnesota, project ........ 37 Figure 29. Morrissey Builders: Energy modeling results for the Lake Elmo, Minnesota, project.... 39 Figure 30. Urban Homeworks: Front elevation of the North Minneapolis, Minnesota, project......... 40 Figure 31. Urban Homeworks: Expanded polystyrene continuous insulation with embedded polypropylene attachment studs of the North Minneapolis, Minnesota, project.

Figure 32. Urban Homeworks: ICF foundation, closed-cell spray foam at rim joist, and sealed ductwork located within the thermal enclosure of the North Minneapolis, Minnesota, project 43

Figure 33. Urban Homeworks: Energy modeling results for the North Minneapolis, Minnesota, project.

Figure 34. Sam Rashkin, chief architect of DOE, at the Cobblestone Homes DOE Innovation event49 


\section{List of Tables}

Table 1. Amaris Custom Homes: Model Home Project ..................................................................... 7

Table 2. Amaris Custom Homes: Bloomington, Minnesota, Project ................................................. 13

Table 3. Amaris Custom Homes: Vadnais Heights, Minnesota, Project ........................................... 17

Table 4. Amaris Custom Homes: Apple Valley, Minnesota, Project ................................................... 21

Table 5. Amaris Custom Homes: White Bear Township, Minnesota, Project.................................. 25

Table 6. Amaris Custom Homes: Mound, Minnesota, Project............................................................ 28

Table 7. Amaris Custom Homes: Stillwater, Minnesota, Project................................................... 31

Table 8. Cobblestone Homes: Midland, Michigan, Project ......................................................... 33

Table 9. Morrissey Builders: Lake Elmo, Minnesota, Project............................................................. 38

Table 10. Urban Homeworks: North Minneapolis, Minnesota, Project ............................................... 41 


\section{Definitions}

ACH50

AFUE

BEopt

CFL

DOE

EF

ERV

$\mathrm{ft}^{2}$

HERS

HRV

HSPF

HVAC

ICF

$\mathrm{kW}$

LED

Low-e

MMBtu

MMBtu/y

PV

PVC

SEER

SHGC

ZERH air changes per hour at 50 pascals

annual fuel utilization efficiency

Building Energy Optimization

compact fluorescent lamp

U.S. Department of Energy

Energy Factor

energy recovery ventilator

square feet

Home Energy Rating System

heat recovery ventilator

heating seasonal performance factor

heating, ventilating, and air conditioning

insulating concrete forms

kilowatt

light-emitting diode

low emissivity

million British thermal units

million British thermal units per year

photovoltaic

polyvinyl chloride

Seasonal Energy Efficiency Ratio

solar heat gain coefficient

Zero Energy Ready Home 


\section{Executive Summary}

Achieving the U.S. Department of Energy (DOE) Zero Energy Ready Home (ZERH) program certification can be challenging for some builders. This report is designed to document the process and outcomes involved in meeting this rigorous standard while helping homebuilders in Climate Zones 5 and 6 in the Upper Midwest achieve ZERH certification.

For this research, local builders volunteered to build at least one ZERH-qualified house. NorthernSTAR, in conjunction with program partner Building Knowledge, Inc., provided technical support to the builders during the design and construction process. In addition, participants had their program questions answered and received technical information about program requirements and critical building components and processes.

\section{Commonly-Found Construction Technique Improvements}

The volunteer builders' homes meet or exceed the 2012 International Energy Conservation Code requirements. Typical improvements over theses requirements include:

- Improved infiltration performance

- Increased high-efficacy lighting

- Increased foundation insulation levels

- Energy recovery ventilation.

\section{Energy Modeling}

Energy consumption predictions were made using two software tools: REM/Rate ${ }^{\mathrm{TM}}$ and BEopt $^{\mathrm{TM}}$. REM/Rate was used to generate Home Energy Rating System ratings and verify qualification under DOE ZERH. Detailed inputs used in REM/Rate were used to duplicate the houses as closely as possible in BEopt. Energy model predictions were in close agreement in half of the homes, while they differed significantly in the other half. Modeling limitations were identified to explain the differences, including:

- Geometry that can't be accommodated in BEopt:

- House plans with geometry including angles other than $90^{\circ}$

- Unconventional conditioned attics under complex roof shapes that don't include additional exterior wall areas

○ Walk-out basements and other complex basement conditions

- Certain complex ceiling geometries

○ Half-story upper floors that cantilever beyond the first floor

- Window types that vary within a given elevation (BEopt can model differing window types on different elevations, but not multiple types on one elevation).

\section{Key Conclusions}

The two most obvious barriers faced by the builders include overcoming the learning curve about the ZERH program requirements and conveying those requirements to their staff and trade 
contractors. The Building America Solution Center was a valuable resource for the builders and designers, especially in addressing the strategies for above-grade wall insulation to maximize performance and minimize risk and cost. Energy modeling also supported a common understanding of the energy impact of design decisions, building components, and energyconsuming devices and systems.

Other barriers to effectively implementing ZERH certification include:

- Heating, ventilating, and air conditioning (HVAC) quality installation:

- There is a limited availability of credentialed HVAC contractors in most markets to work on ENERGY STAR ${ }^{\circledR}$-certified projects

○ Our experience demonstrates that even with credentialing, field crews' lack of experience and training often results in HVAC system designs and installations that do not meet the program requirements

- Exterior wall continuous insulation:

- Placing insulation on the outside of exterior wall assemblies presents challenges for attaching structural deck ledgers while maintaining a thermal break

- Integration with fenestrations and attaching siding are not practices builders and trade contractors are accustomed to.

It is clear builders can achieve the ZERH certification and will see the performance results in their new homes. At the time this publication was drafted, four qualifying homes were complete, and an additional three were under construction to be completed later in 2016.

To help builders convey the benefits of ZERH homes to homebuyers, realtors, appraisers, and the press, enhanced messaging is needed. Most of the homes presented in this study received enhanced public interest through media events, feature newspaper articles, site tours, and social media posts, demonstrating an increasing acceptance by the public of the benefits of energyefficient homes. Two builders noted that participating in the ZERH program provided them with a competitive advantage in the marketplace at reasonable construction costs, resulting in extremely satisfied clients who recommend the builders to friends and family. 


\section{Introduction}

The purpose of this project is to document the feasibility of attaining the U.S. Department of Energy (DOE) Zero Energy Ready Home (ZERH) (formerly known as DOE Challenge Home) standards in a Midwestern cold climate market (Climate Zones 5 and 6). The aim of DOE's $\mathrm{ZERH}$ is to enable the construction of houses that are "so energy efficient, that a renewable energy system can offset all or most of [their] annual energy consumption" (DOE 2015). This goal aligns with DOE's Building America Program goal to reduce home energy use by $30 \%-$ $50 \%$ (compared to 2009 energy codes for new homes) while at the same time not compromising building durability or human health.

DOE ZERH must:

- Comply with ENERGY STAR for homes ${ }^{1}$ and the inspection checklists ${ }^{2}$ for

○ Thermal enclosure

- Heating, ventilating, and air conditioning (HVAC) quality installation [contractor and the Home Energy Rating System (HERS)]

○ Water management.

- Feature energy-efficient appliances and fixtures that are ENERGY STAR qualified

- Use high-performance windows that meet ENERGY STAR ${ }^{3}$ specifications

- Meet 2012 International Energy Conservation Code levels for insulation. In some states, 2015 International Energy Conservation Code insulation levels are required

- Follow the latest proven research recommendations by installing ducts in conditioned space or using a high-performance alternative as defined in the program specs

- Conserve water and energy through an efficient hot water distribution system that provides rapid hot water to the homeowner

- Provide comprehensive indoor air quality through full certification by the U.S. Environmental Protection Agency's Indoor airPLUS ${ }^{4}$ program

- Accomplish savings on the cost of future solar photovoltaic (PV) installations by following the PV-ready checklist ${ }^{5}$ for climates with significant solar insolation. This checklist references the U.S. Environmental Protection Agency's solar electric guide. ${ }^{6}$

\footnotetext{
${ }^{1}$ See http://www.energy.gov/eere/buildings/downloads/energy-star-certified-homes-version-3-rev-07-nationalprogram-requirements.

${ }^{2}$ See http://www.energy.gov/eere/buildings/downloads/energy-star-certified-homes-version-3-rev-07-inspectionchecklists-national.

${ }^{3}$ See http://www.energystar.gov/products/building_products/residential_windows_doors_and_skylights.

${ }^{4}$ See http://www.epa.gov/indoorairplus.

${ }^{5}$ See http://www.energy.gov/eere/buildings/downloads/doe-zero-energy-ready-home-pv-ready-checklist.

${ }^{6}$ See http://www.energy.gov/eere/buildings/downloads/renewable-energy-ready-home-solar-photovoltaicspecifications.
} 
This project identifies builders willing to participate in a program that will put them among the top $1 \%$ of builders in the region in terms of their ability to profitably build new homes that are a substantial step up in performance relative to the rest of the new home market. 


\section{Approach}

The essential components of this research consisted of marketing the DOE ZERH concept to local builders to solicit volunteers who were willing to build at least one qualified house, answering their questions about the program and providing technical knowledge about program requirements and critical building components and processes, and verifying that the requirements had been met on candidate houses. The approach involved the following steps:

1. Assist builders in understanding the DOE ZERH concept, criteria, and registration.

2. Provide technical support to the builders through plan reviews, technology/product selections, and energy modeling.

3. Document the process and final product using a case study format.

4. Provide short-term monitoring, using utility bill data when possible, to compare actual energy use to design models.

\subsection{Volunteer Builders}

Amaris Custom Homes of White Bear Lake, Minnesota, committed to constructing 100\% of their homes to DOE ZERH requirements. To date, the company has completed three certified homes, one of which is a 2015 Housing Innovation Award winner.

Cobblestone Homes of Saginaw, Michigan, has completed a qualifying home, which was a 2014 Housing Innovation Award winner, and it is currently developing strategies to commit to constructing $100 \%$ of their homes to DOE ZERH requirements.

Morrissey Builders of Minneapolis, Minnesota, has experience in constructing certified projects such as homes certified by Minnesota GreenStar, Passive House Institute US Certification, and Leadership in Energy and Environmental Design.

Urban Homeworks of Minneapolis, Minnesota, is a faith-based nonprofit organization that provides dignified housing and creates construction training opportunities by weaving together a network of engaged neighbors and mobilizing volunteers. ZERH is part of the City of Minneapolis's Green Homes North Initiative to build 100 energy-efficient homes throughout five years to revitalize neighborhoods in North Minneapolis. The project is also a training ground for Urban Construction Company and Youthbuild, wherein youth and young adults learn skills and make each trainee a more sought-after asset for employers.

Detailed analyses of the business and building practices for Amaris and Cobblestone Homes are available in VonThoma and Ojczyk (2012).

\subsection{Technical Support}

\subsubsection{Technical Support from the University of Minnesota}

Pat Huelman and Garrett Mosiman from the University of Minnesota met with builders and their subcontractors on an as-needed basis. These meetings were used to communicate ZERH requirements and to talk through applying the requirements to the builders' home designs. 


\subsubsection{Technical Support from HERS Raters}

Building Knowledge, Inc., provided the participating builders with technical support and assistance including verification and testing to meet DOE ZERH program requirements. Building Knowledge is a team lead for DOE's NorthernSTAR Building America Program, and it has been a technical resource for the Building America Program for more than 15 years.

\subsection{Energy Modeling}

Two energy modeling software packages were used to model each house: REM/Rate, produced by NORESCO, LLC; and Building Energy Optimization (BEopt), a free energy modeling software application produced by the National Renewable Energy Laboratory. REM/Rate is used nationally to certify homes using standards such as DOE ZERH, and it was used during this project to inform decisions during the design and construction process. BEopt is used extensively in DOE's Building America Program, and it was used here to enable comparisons among ZERH projects in this study and other Building America work.

Building Knowledge produced energy models using REM/Rate in the process of generating HERS ratings as a part of the ZERH certification process. Detailed summaries of building characteristics modeled in REM/Rate were used to generate BEopt inputs to ensure that the models were as close as possible to being identical. Models were generated using BEopt 2.3.0.2 and run using the EnergyPlus simulation engine. Three outputs from BEopt are reported: B10 Benchmark source energy use, as-designed source energy use, and as-designed site energy use. As-designed site energy use can be compared directly to REM/Rate site energy use. Note that the two programs allocate end-use energy differently. REM/Rate outputs include four categories: heating, cooling, water heating, and lights/appliances. BEopt outputs also include heating, cooling, and water heating; however, lights/appliances are disaggregated into the categories of large appliances, HVAC fan/pump, lights, vent fan, and miscellaneous. This difference in categorization may account for some of the differences in allocated energy between the models.

Establishing whether or not results are similar between the two tools may be useful for further transfer of knowledge among researchers (using BEopt) and energy raters in the field. 


\section{DOE ZERH Designs}

\subsection{Amaris Custom Homes: Saint Paul, Minnesota, Model Home Project}

\subsubsection{Basic Project Information}

This 3,542- $\mathrm{ft}^{2}, 5$-bedroom, 4-bathroom walk-out rambler with finished basement is the first DOE Challenge Home in Minnesota. This home was completed in September, 2013, and it is located in Climate Zone 6.

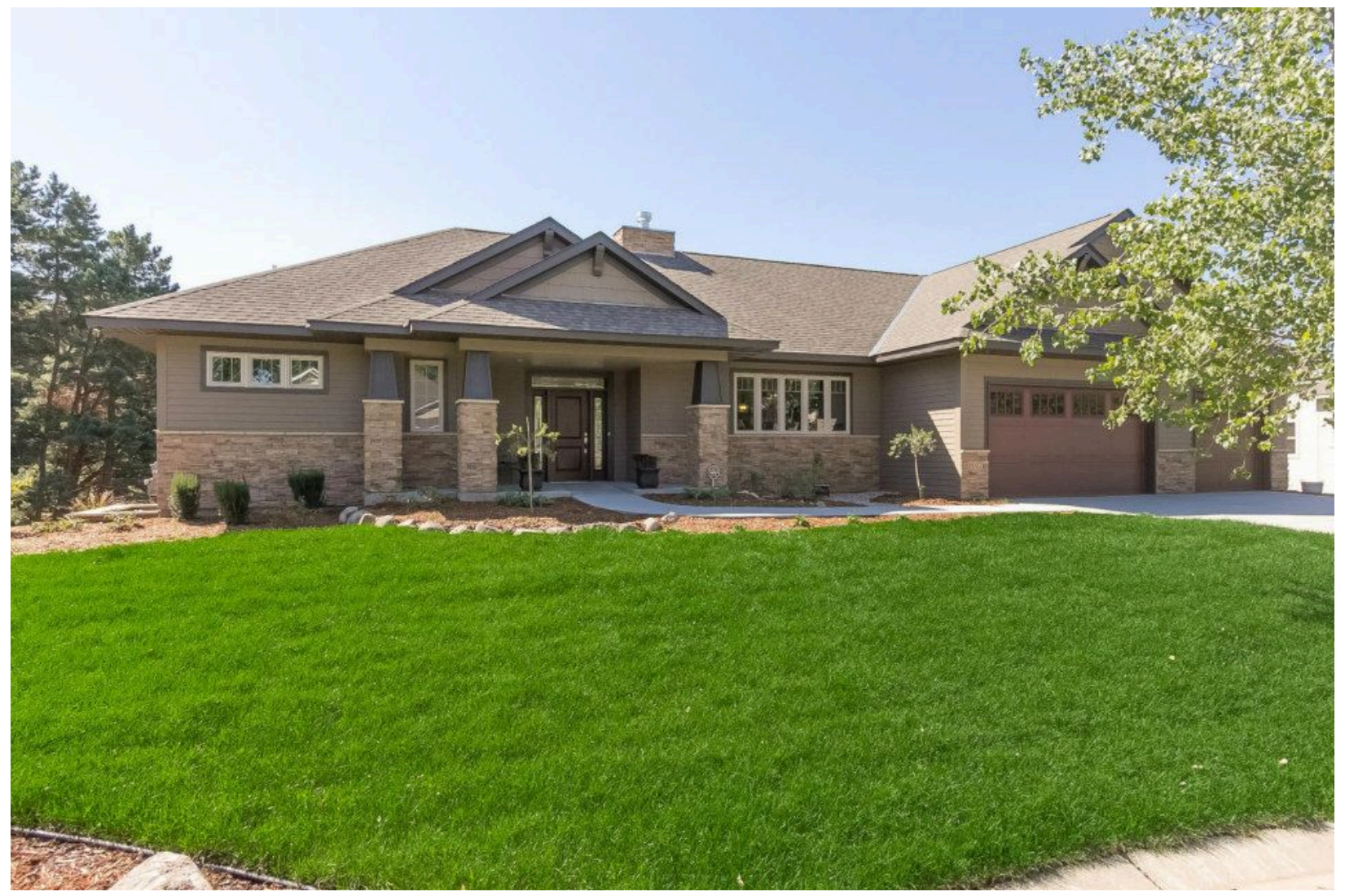

Figure 1. Amaris Custom Homes: Front elevation of the St. Paul, Minnesota, project 


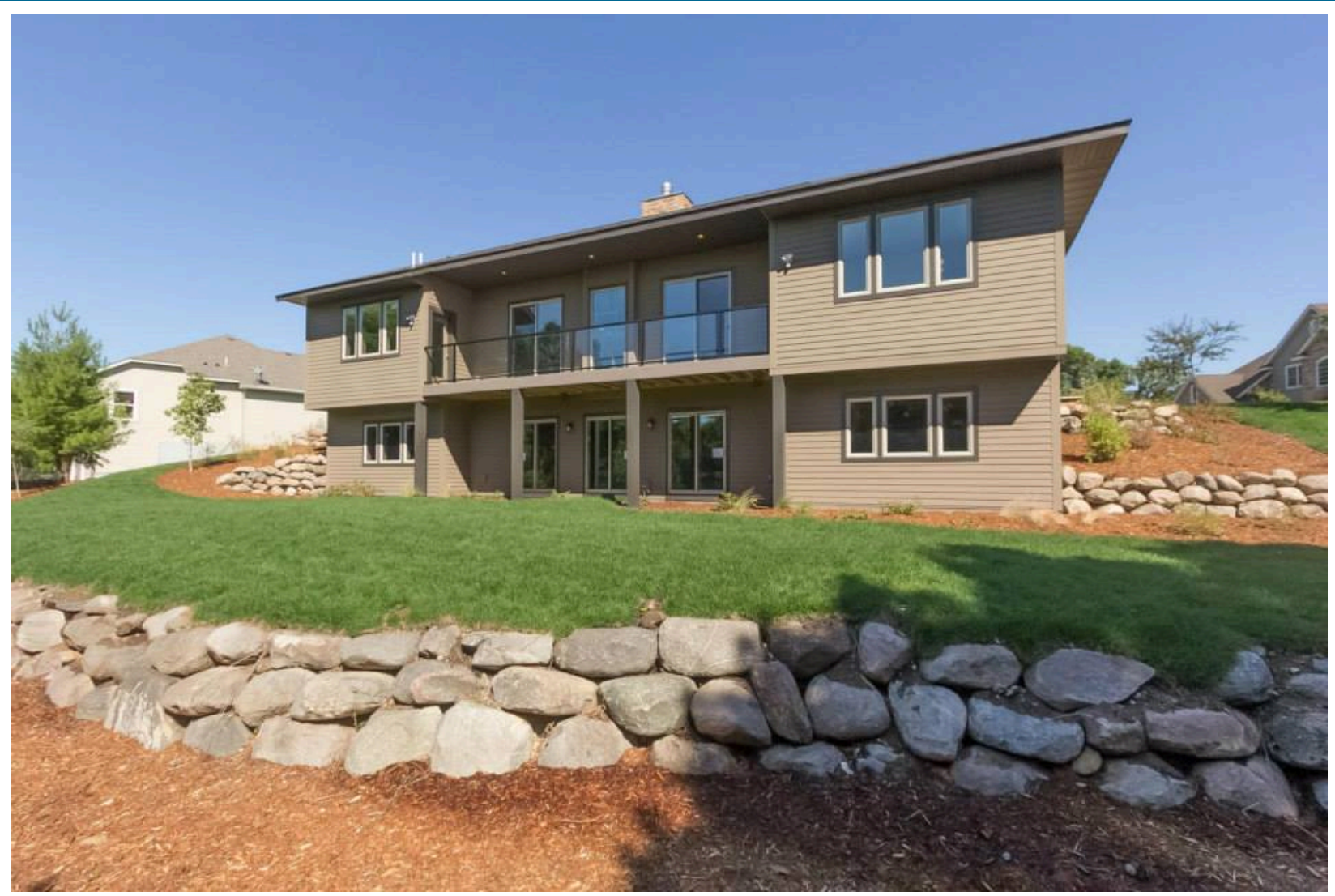

Figure 2. Amaris Custom Homes: Rear elevation of the St. Paul, Minnesota, project

This report is available at no cost from the National Renewable Energy Laboratory (NREL) at www.nrel.gov/publications. 


\subsubsection{Technical Characteristics of Typical Construction Practices and DOE ZERH Solutions}

The typical construction practices for Amaris Custom Homes are close to the ZERH requirements.

Table 1. Amaris Custom Homes: Model Home Project

\begin{tabular}{|c|c|c|}
\hline Measure & Typical Construction Practices & ZERH Solution \\
\hline Infiltration & $1.00 \mathrm{ACH} 50^{\mathrm{a}}$ & 0.84 ACH50 \\
\hline Cooling Equipment & $14 \mathrm{SEER}^{\mathrm{b}}$ & 14.5 SEER \\
\hline Heating Equipment & Natural gas, 96 AFUE $^{\mathrm{c}}$ & Natural gas, 96.1 AFUE \\
\hline Water Heater & Natural gas, $0.90 \mathrm{EF}^{\mathrm{d}}$ & Natural gas, $0.80 \mathrm{EF}$ \\
\hline Lighting & 50\% ENERGY STAR & 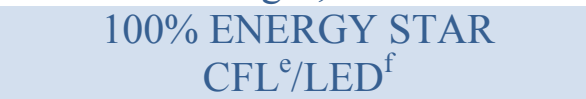 \\
\hline Thermostat & Programmable & Programmable \\
\hline Dishwasher & ENERGY STAR rated & ENERGY STAR rated \\
\hline Refrigerator & ENERGY STAR rated & ENERGY STAR rated \\
\hline Clothes Washer & ENERGY STAR rated & ENERGY STAR rated \\
\hline Ceiling Insulation & $\begin{array}{c}\text { 2-in. closed-cell spray foam on lid } \\
\text { with R-48 blown fiberglass. } \\
\text { Total R-65.5 }\end{array}$ & $\begin{array}{c}\text { 2-in. closed-cell spray foam on lid } \\
\text { with R-48 blown fiberglass. } \\
\text { Total R-65.5 }\end{array}$ \\
\hline $\begin{array}{l}\text { Above-Grade Wall } \\
\text { Insulation }\end{array}$ & $\begin{array}{l}\text { R-5 continuous exterior } \\
\text { insulation, } 3 \text {-in. closed-cell spray } \\
\text { foam in cavity. Total R-24.5 }\end{array}$ & $\begin{array}{l}\text { R-5 continuous exterior } \\
\text { insulation, } 3 \text {-in. closed-cell spray } \\
\text { foam in cavity. Total R-25 }\end{array}$ \\
\hline Foundation Insulation & R-10 foundation wall & $\begin{array}{c}\text { 14-in. } \mathrm{ICF}, \mathrm{g} \text { R-25, } \\
\text { under slab R-20 }\end{array}$ \\
\hline Windows & $\begin{array}{c}\text { Double-pane, argon-filled; } \\
\text { PVC } \\
\text {-framed; Low-e windows } \\
\text { with U- } 0.25\end{array}$ & $\begin{array}{l}\text { Double-pane, argon-filled; } \\
\text { PVC-framed; Low-e windows } \\
\text { with U-0.25 and } 0.49 \text { SHGC }^{j}\end{array}$ \\
\hline $\begin{array}{l}\text { Reduced Lumber from } \\
\text { Advanced Framing }\end{array}$ & $\begin{array}{l}2 \times 6 \text {-in. walls } 24 \text {-in. on center, } \\
\text { open corners and single-ply } \\
\text { headers }\end{array}$ & $\begin{array}{c}2 \times 6 \text {-in. walls } 24 \text {-in. on center, } \\
\text { open corners and single-ply } \\
\text { headers }\end{array}$ \\
\hline Ventilation & $\mathrm{HRV}^{\mathrm{k}}$ & $E_{R V^{1}}$ \\
\hline Duct Systems & $\begin{array}{l}\text { Located within the thermal and } \\
\text { air barrier, fully ducted, sealed } \\
\text { with mastic }\end{array}$ & $\begin{array}{l}\text { Located within the thermal and } \\
\text { air barrier, fully ducted, sealed } \\
\text { with mastic }\end{array}$ \\
\hline PV & None & $12.2 \mathrm{~kW}^{\mathrm{m}}$ \\
\hline \multicolumn{3}{|c|}{$\begin{array}{l}\text { a Air changes per hour at } 50 \text { pascals } \\
\text { b Seasonal energy efficiency ratio } \\
{ }^{\mathrm{c}} \text { Annual fuel utilization efficiency } \\
{ }^{\mathrm{d}} \text { Energy Factor } \\
{ }^{\mathrm{e}} \text { Compact fluorescent lamp } \\
{ }^{\mathrm{f}} \text { Light-emitting diode } \\
{ }^{\mathrm{g}} \text { Insulating concrete forms }\end{array}$} \\
\hline
\end{tabular}

This report is available at no cost from the National Renewable Energy Laboratory (NREL) at www.nrel.gov/publications. 


\subsubsection{Energy Modeling}

Figure 3 shows the energy modeling results for Amaris Custom Homes' St. Paul, Minnesota, project. Predictions of site energy use were nearly identical between the two models: 99 Million British thermal units per year (MMBtu/yr) for BEopt and MMBtu/yr REM/Rate. In addition, predicted PV output is very similar: 46 and $48 \mathrm{MMBtu} / \mathrm{yr}$, respectively. BEopt inputs and HERS information can be found in Appendix A and Appendix B.

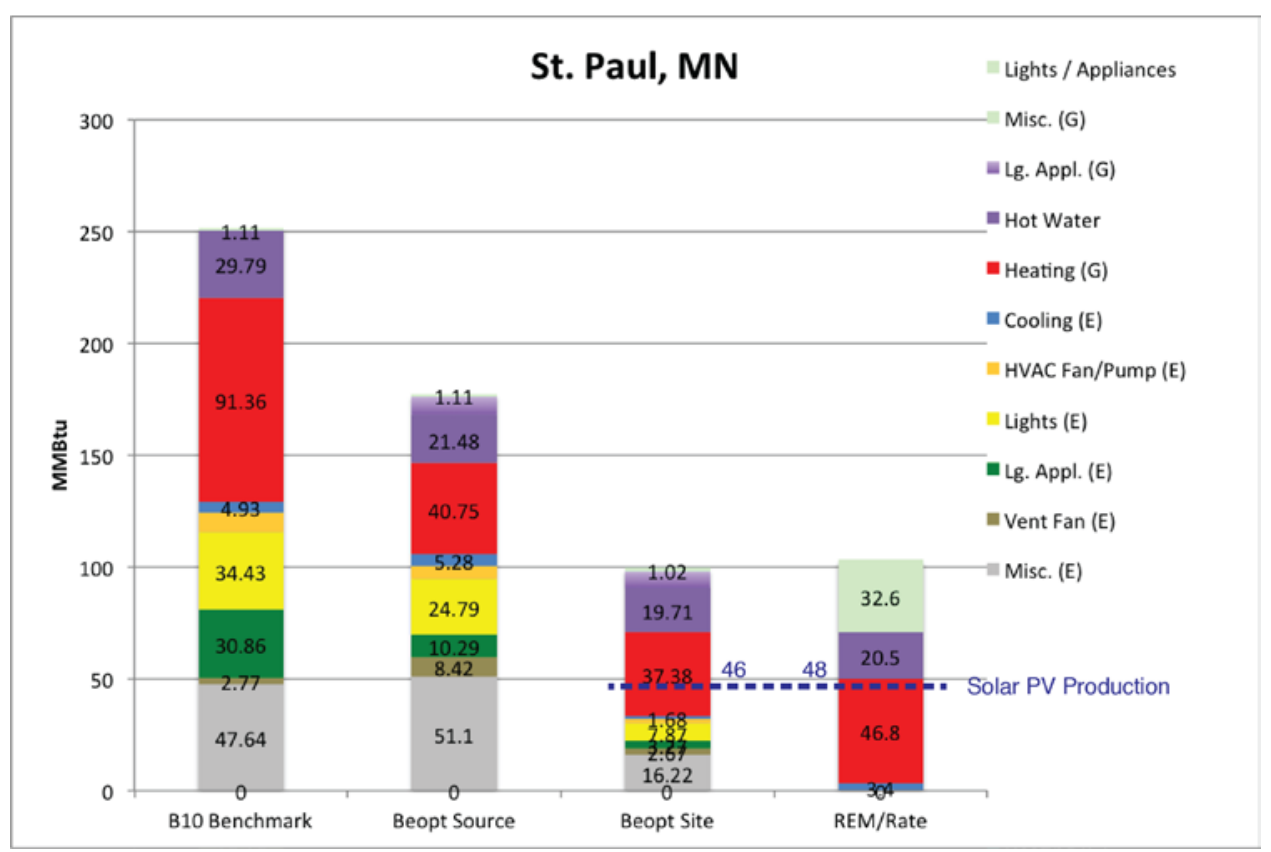

Figure 3. Amaris Custom Homes: Energy modeling results for the St. Paul, Minnesota, project

\subsubsection{Initial Energy Use}

Figure 4 summarizes the actual energy use and predicted energy use as modeled in BEopt. Note that Year 2 energy use does not include data for July 2015, which was not available at the time of publication. Figure 5 and Figure 6 show the first two years broken down by billing period. Firstyear electric consumption was only slightly higher than modeled. Year 2 appears to be on track to consume less electricity than Year 1 and that of the predicted value. In both years, however, gas consumption was significantly higher than predicted.

Gas consumption roughly follows the pattern predicted in the model; that is, consumption rises during the heating season and declines in warmer months. Consumption in the summer can be primarily attributed to water heating but also to clothes drying and cooking. Electric consumption, however, appears to be consumed in a much more stochastic way, perhaps reflecting the importance of occupant behavior and plug loads to electric energy use. 


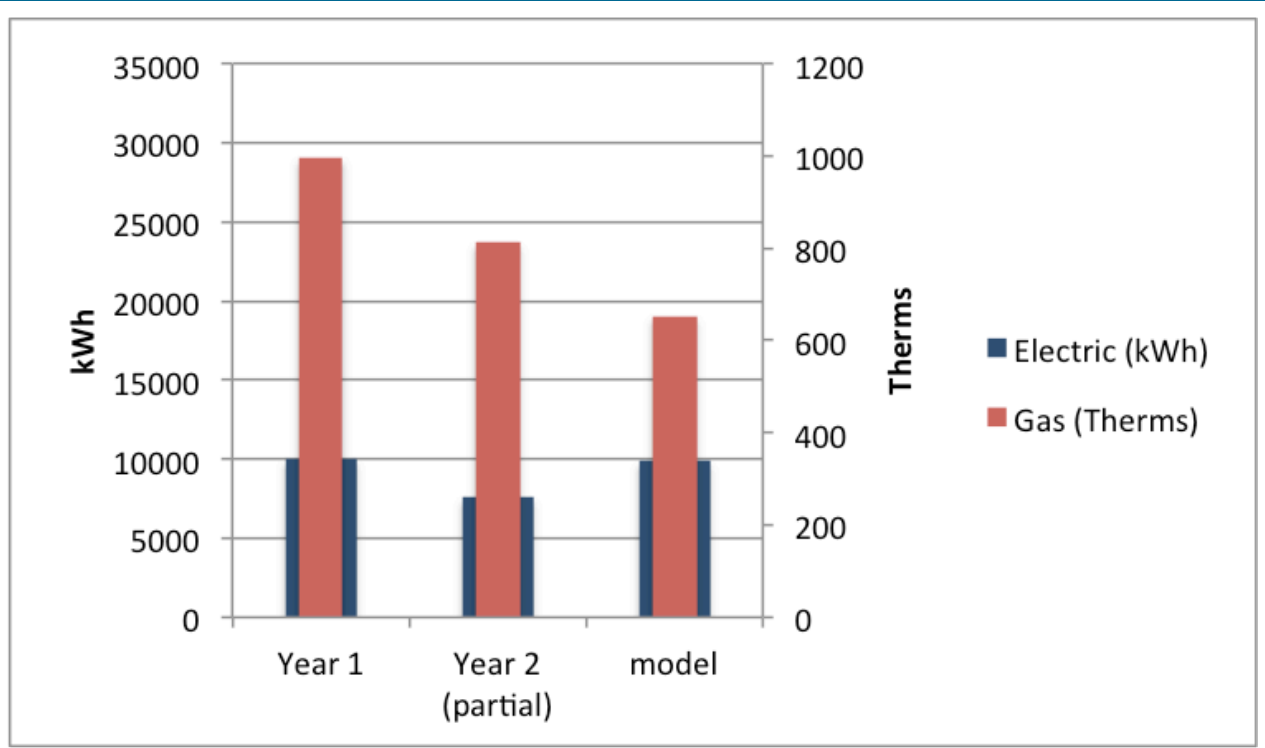

Figure 4. Amaris Custom Homes: Actual compared to modeled annual energy use for the St. Paul, Minnesota, project

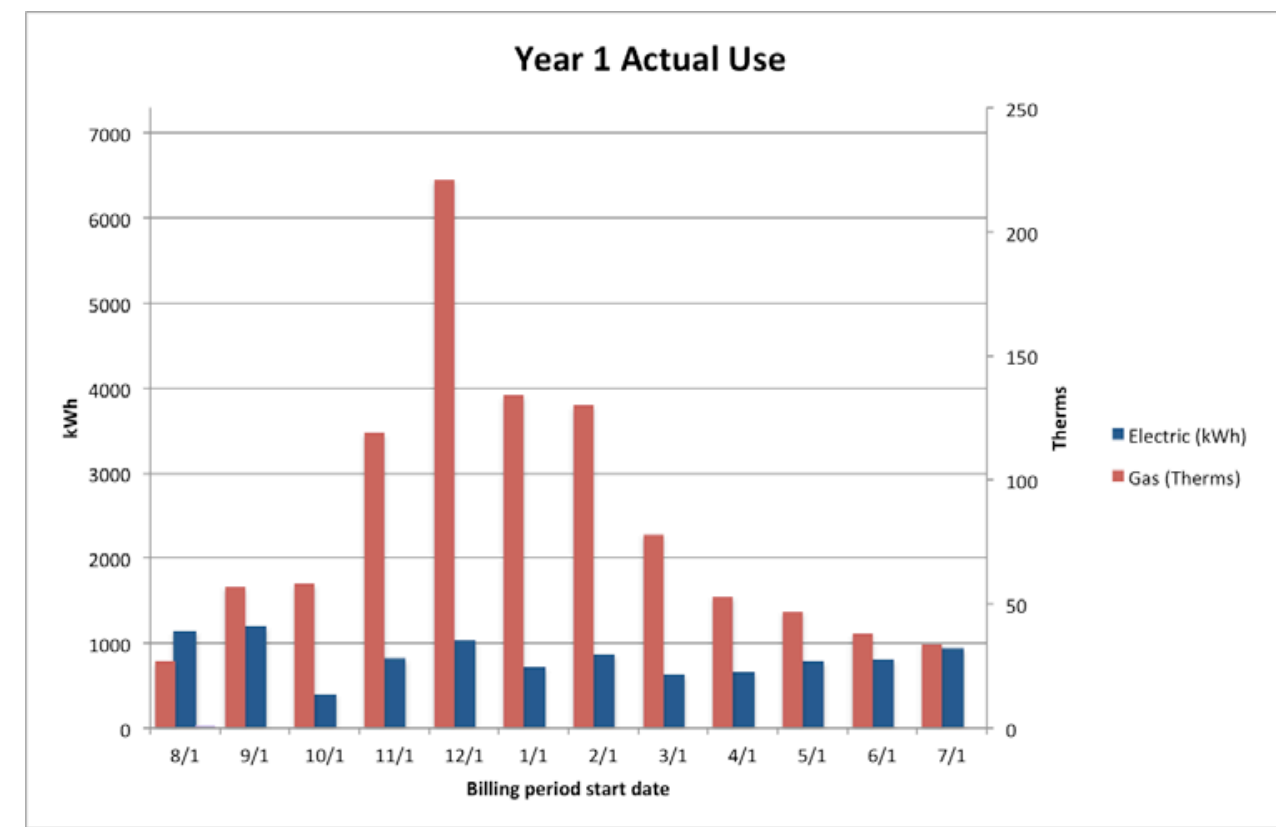

Figure 5. Amaris Custom Homes: Year 1 actual monthly energy use for the St. Paul, Minnesota, project 


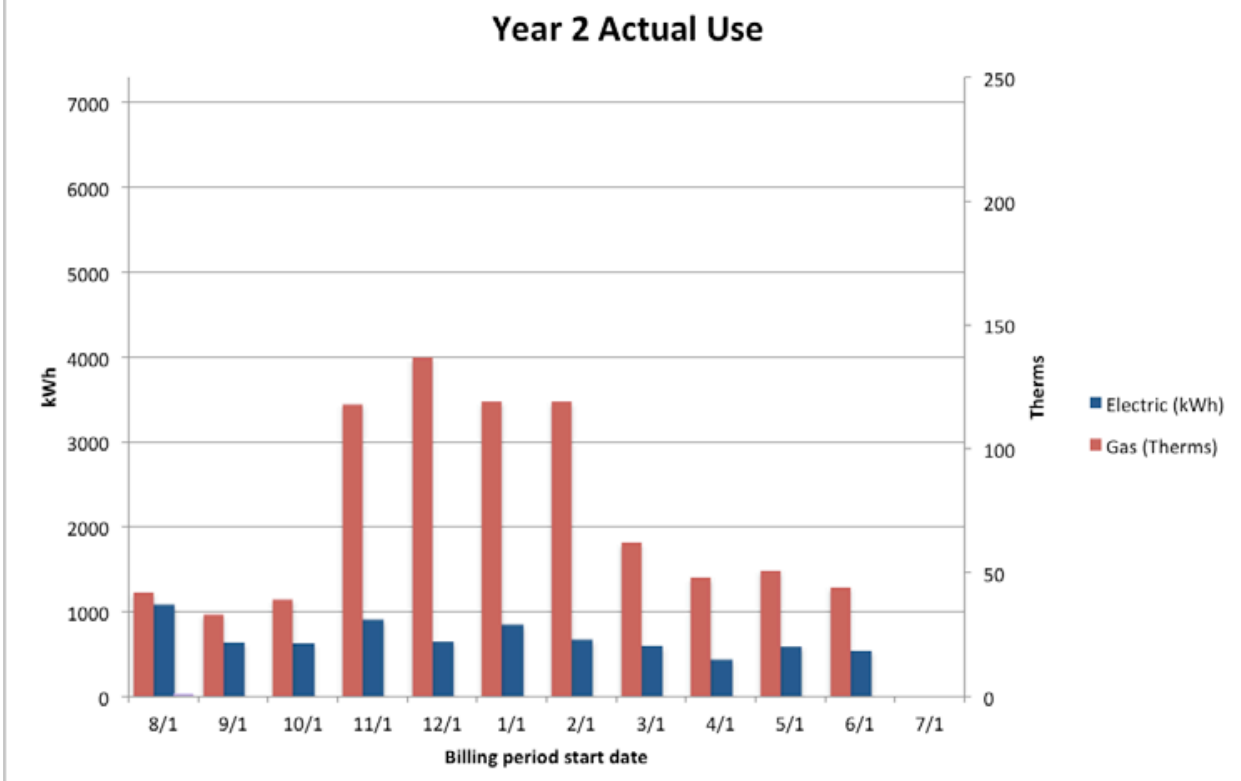

Figure 6. Amaris Custom Homes: Year 2 actual monthly energy use for the St. Paul, Minnesota, project

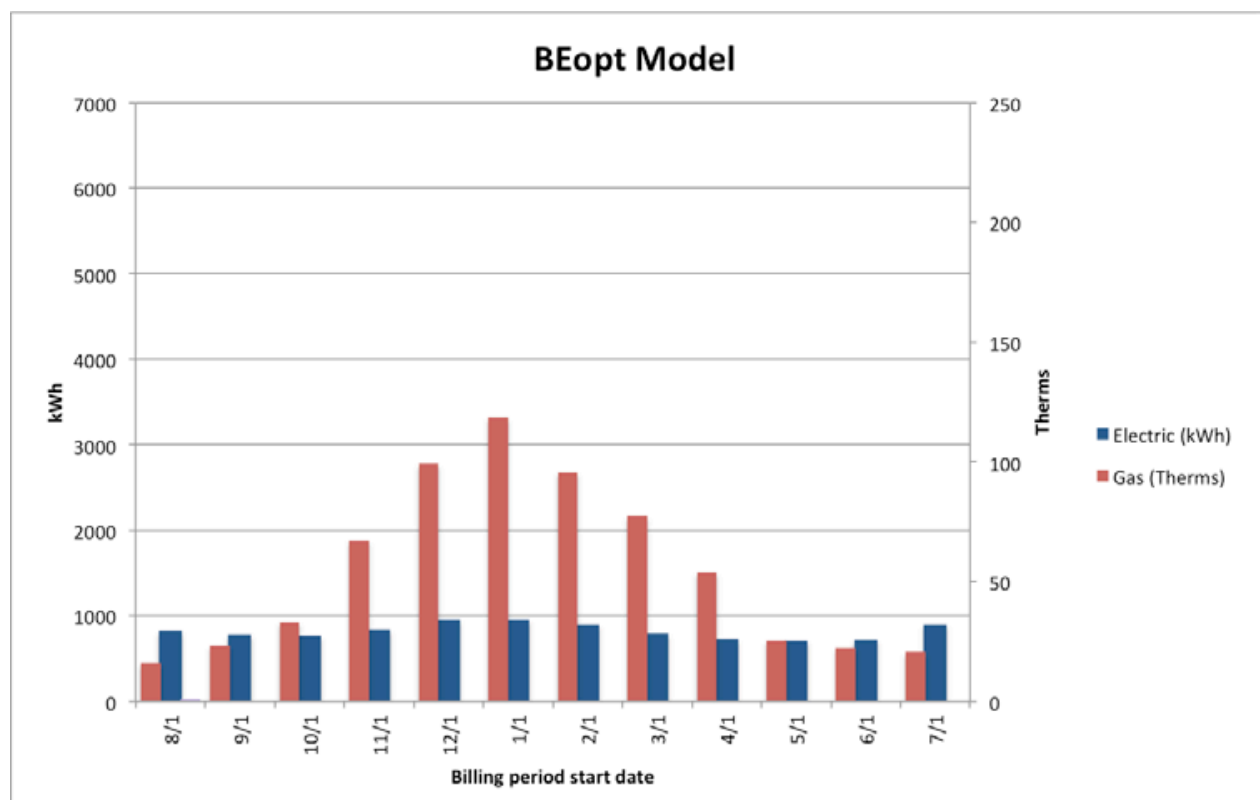

Figure 7. Amaris Custom Homes: Modeled monthly energy use for the St. Paul, Minnesota, project 


\subsection{Amaris Custom Homes: Bloomington, Minnesota, Project}

\subsubsection{Basic Project Information}

This 3,364- $\mathrm{ft}^{2}$, 4-bedroom, 21/2-bathroom, 2-story home with conditioned basement is located in Climate Zone 6.

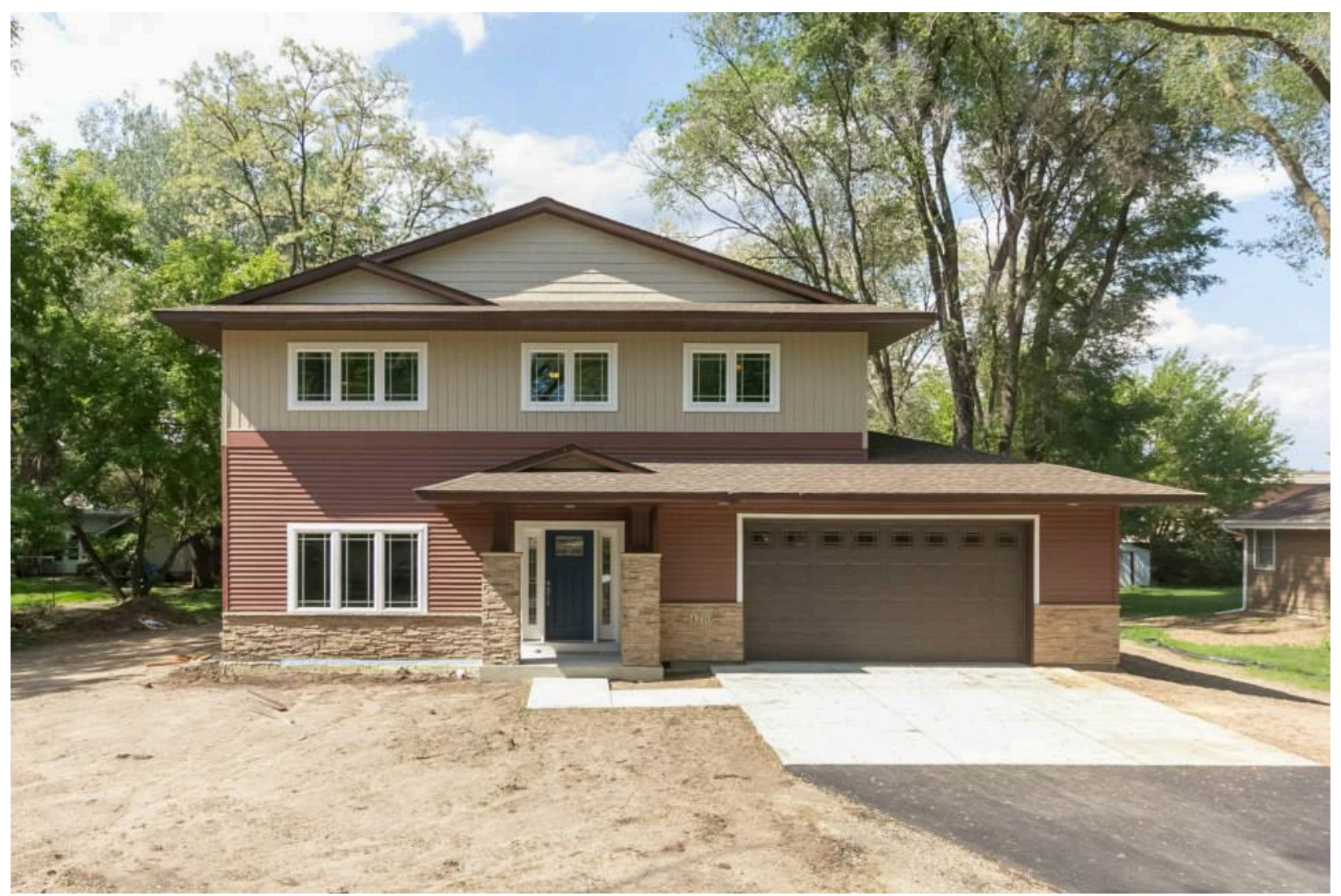

Figure 8. Amaris Custom Homes: Front elevation of the Bloomington, Minnesota, project 


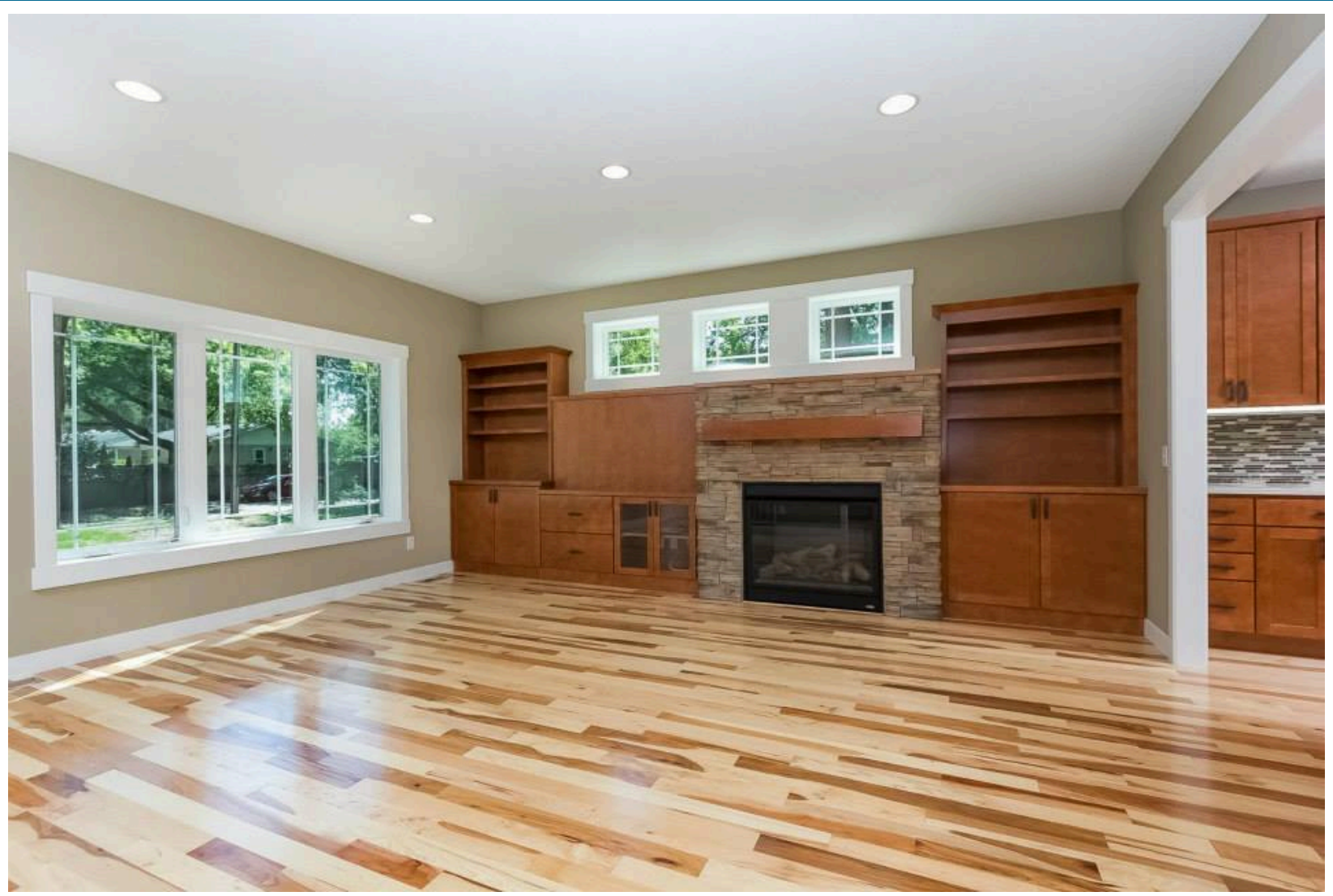

Figure 9. Amaris Custom Homes: Interior of the Bloomington, Minnesota, project 


\subsubsection{Technical Characteristics of Typical Construction Practices and DOE ZERH Solutions}

The typical construction practices of Amaris Custom Homes are close to the ZERH requirements. This home could not be certified under the DOE ZERH program. The builder requires the credentialing of the HVAC contractor as part of the project specifications, and it reviews that requirement at the time of the contract bid and award. This requirement was also reviewed at the required pre-construction meeting; however, despite assurances from the HVAC contractor, the qualification was not achieved until after the project was completed. This home meets all other criteria of the DEO ZERH program.

Table 2. Amaris Custom Homes: Bloomington, Minnesota, Project

\begin{tabular}{|c|c|c|}
\hline Measure & Typical Construction Practices & ZERH Solution \\
\hline Infiltration & $1.00 \mathrm{ACH} 50$ & 0.94 ACH50 \\
\hline Cooling Equipment & 14 SEER & 14.5 SEER \\
\hline Heating Equipment & Natural gas, 96 AFUE & Natural gas, 96 AFUE \\
\hline Water Heater & Natural gas, $0.90 \mathrm{EF}$ & Natural gas, $0.70 \mathrm{EF}$ \\
\hline Lighting & 50\% ENERGY STAR & 96\% ENERGY STAR \\
\hline Thermostat & Programmable & Programmable \\
\hline Dishwasher & ENERGY STAR rated & ENERGY STAR rated \\
\hline Refrigerator & ENERGY STAR rated & ENERGY STAR rated \\
\hline Clothes Washer & ENERGY STAR rated & ENERGY STAR rated \\
\hline Ceiling Insulation & $\begin{array}{l}\text { 2-in. closed-cell spray foam on lid } \\
\text { with R-48 blown fiberglass. } \\
\text { Total R-65.5 }\end{array}$ & $\begin{array}{l}\text { 2-in. closed-cell spray foam on lid } \\
\text { with R-48 blown fiberglass. } \\
\text { Total R-65.5 }\end{array}$ \\
\hline $\begin{array}{c}\text { Above-Grade Wall } \\
\text { Insulation }\end{array}$ & $\begin{array}{l}\mathrm{R}-5 \text { continuous exterior } \\
\text { insulation, } 3 \text {-in. closed-cell spray } \\
\text { foam in cavity. Total R-24.5 }\end{array}$ & $\begin{array}{l}\text { R-5 continuous exterior } \\
\text { insulation, } 3 \text {-in. closed-cell spray } \\
\text { foam in cavity. Total R-24.5 }\end{array}$ \\
\hline Foundation Insulation & $\mathrm{R}-10$ & $\mathrm{R}-10$ \\
\hline Windows & $\begin{array}{l}\text { Double-pane, argon-filled; } \\
\text { PVC-framed; Low-e windows } \\
\text { with U- } 0.25\end{array}$ & $\begin{array}{l}\text { Double-pane, argon-filled; } \\
\text { PVC-framed; Low-e windows } \\
\text { with U-0.24 and } 0.16 \text { SHGC }\end{array}$ \\
\hline $\begin{array}{l}\text { Reduced Lumber from } \\
\text { Advanced Framing }\end{array}$ & $\begin{array}{l}2 \text { x 6-in. walls } 24 \text {-in. on center, } \\
\text { open corners and single-ply } \\
\text { headers }\end{array}$ & $\begin{array}{l}2 \times 6 \text {-in. walls } 24 \text {-in. on center, } \\
\text { open corners and single-ply } \\
\text { headers }\end{array}$ \\
\hline Ventilation & HRV & HRV \\
\hline Duct Systems & $\begin{array}{l}\text { Located within the thermal and } \\
\text { air barrier, fully ducted, sealed } \\
\text { with mastic }\end{array}$ & $\begin{array}{l}\text { Located within the thermal and } \\
\text { air barrier, fully ducted, sealed } \\
\text { with mastic }\end{array}$ \\
\hline
\end{tabular}




\subsubsection{Energy Modeling}

Figure 10 shows the energy modeling results for Amaris Custom Homes' Bloomington,

Minnesota, project. Predictions of site energy use were nearly identical between the two models: $102 \mathrm{MMBtu} / \mathrm{yr}$ for BEopt and $101 \mathrm{MMBtu} / \mathrm{yr}$ REM/Rate. BEopt inputs and HERS information can be found in Appendix C and Appendix D.

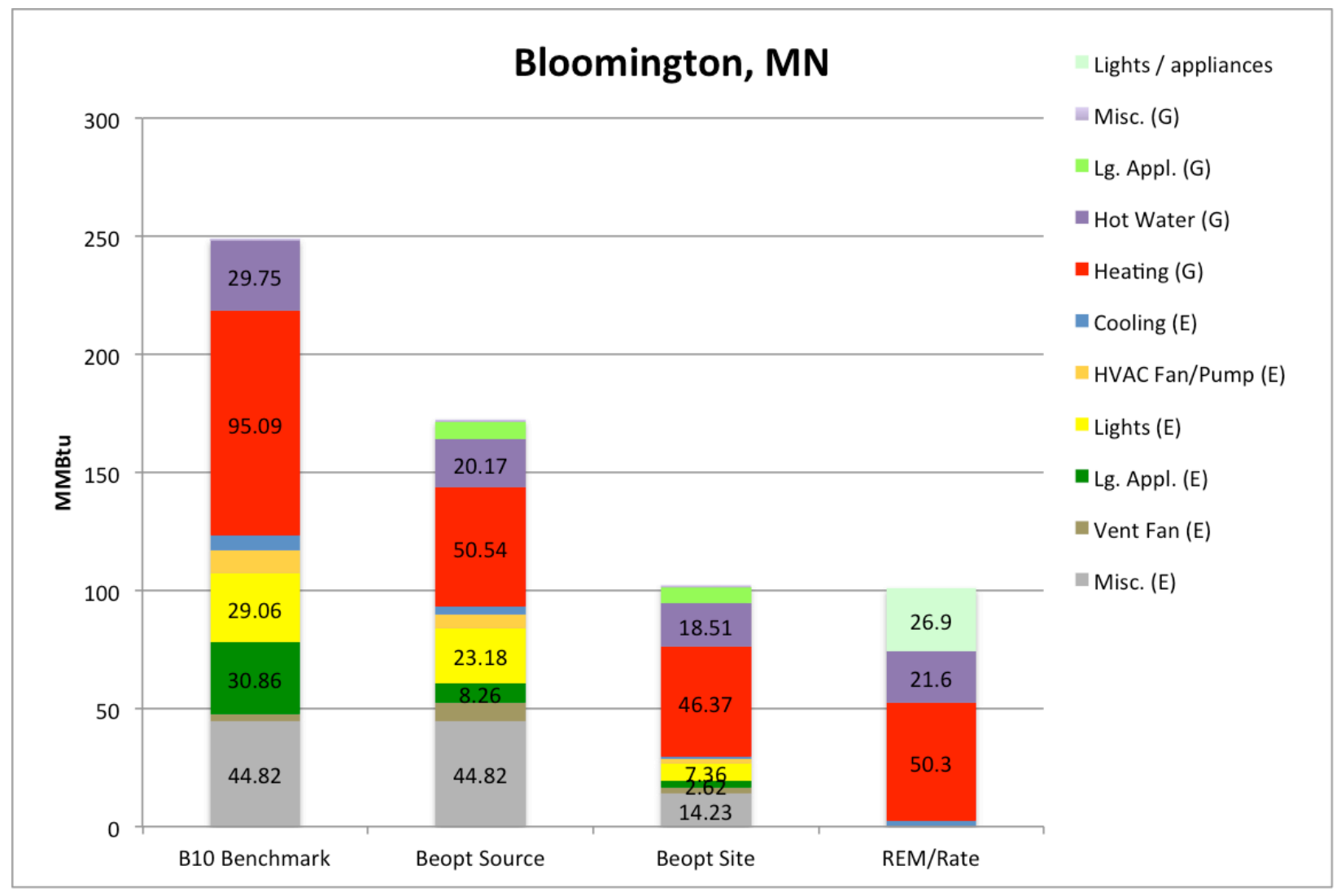

Figure 10. Amaris Custom Homes: Energy modeling results for the Bloomington, Minnesota, project 


\subsection{Amaris Custom Homes: Vadnais Heights, Minnesota, Project}

\subsubsection{Basic Project Information}

This 1,882-ft ${ }^{2}$, 3-bedroom, 2-bathroom, 1-story slab-on-grade home is located in Climate Zone 6. Amaris Custom Homes was notified on August 4, 2015, that this home was a 2015 Housing Innovation Award winner. The Housing Innovation Award application for this home is located in Appendix E.

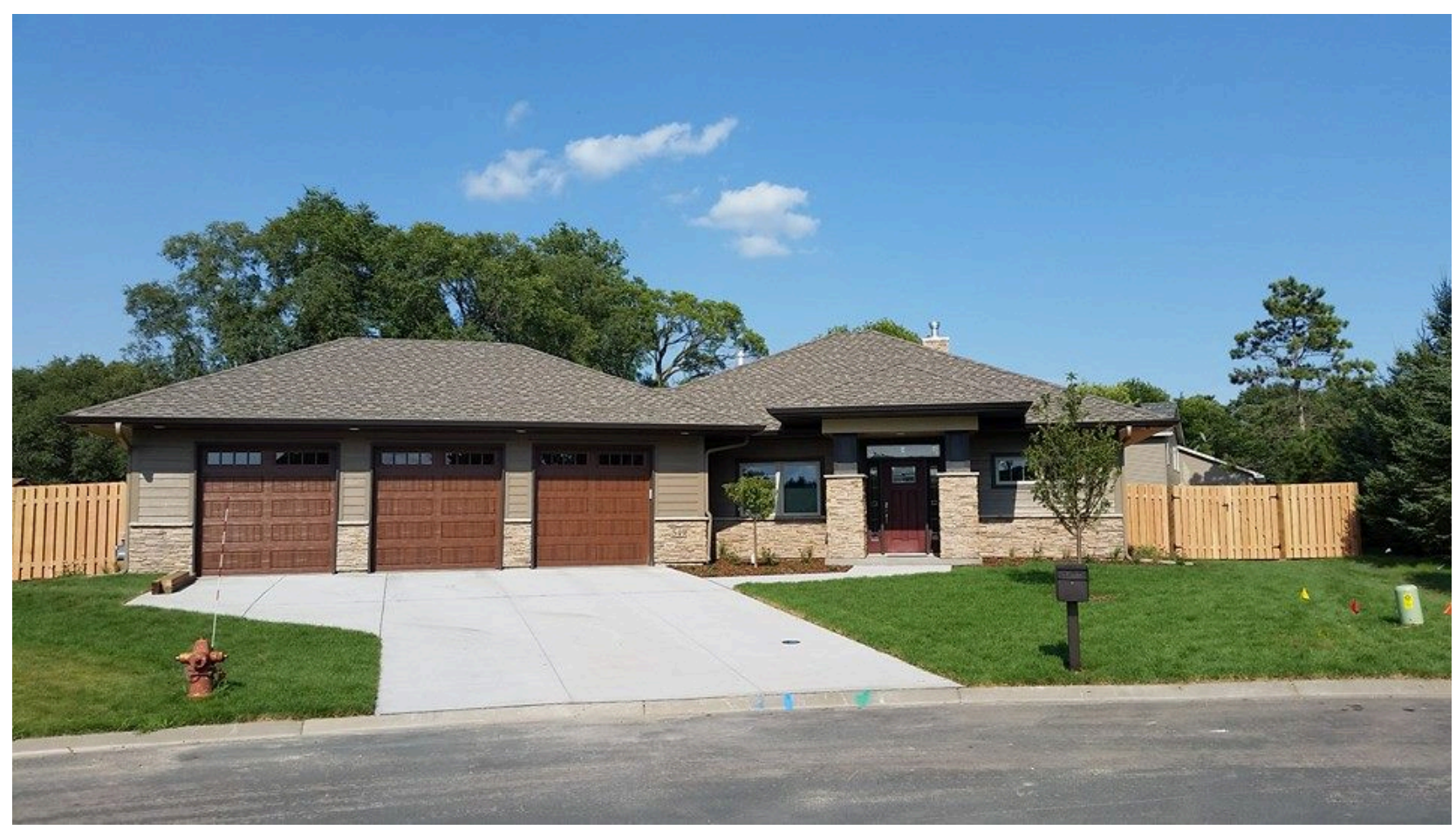

Figure 11. Amaris Custom Homes: Front elevation of the Vadnais Heights, Minnesota, project 


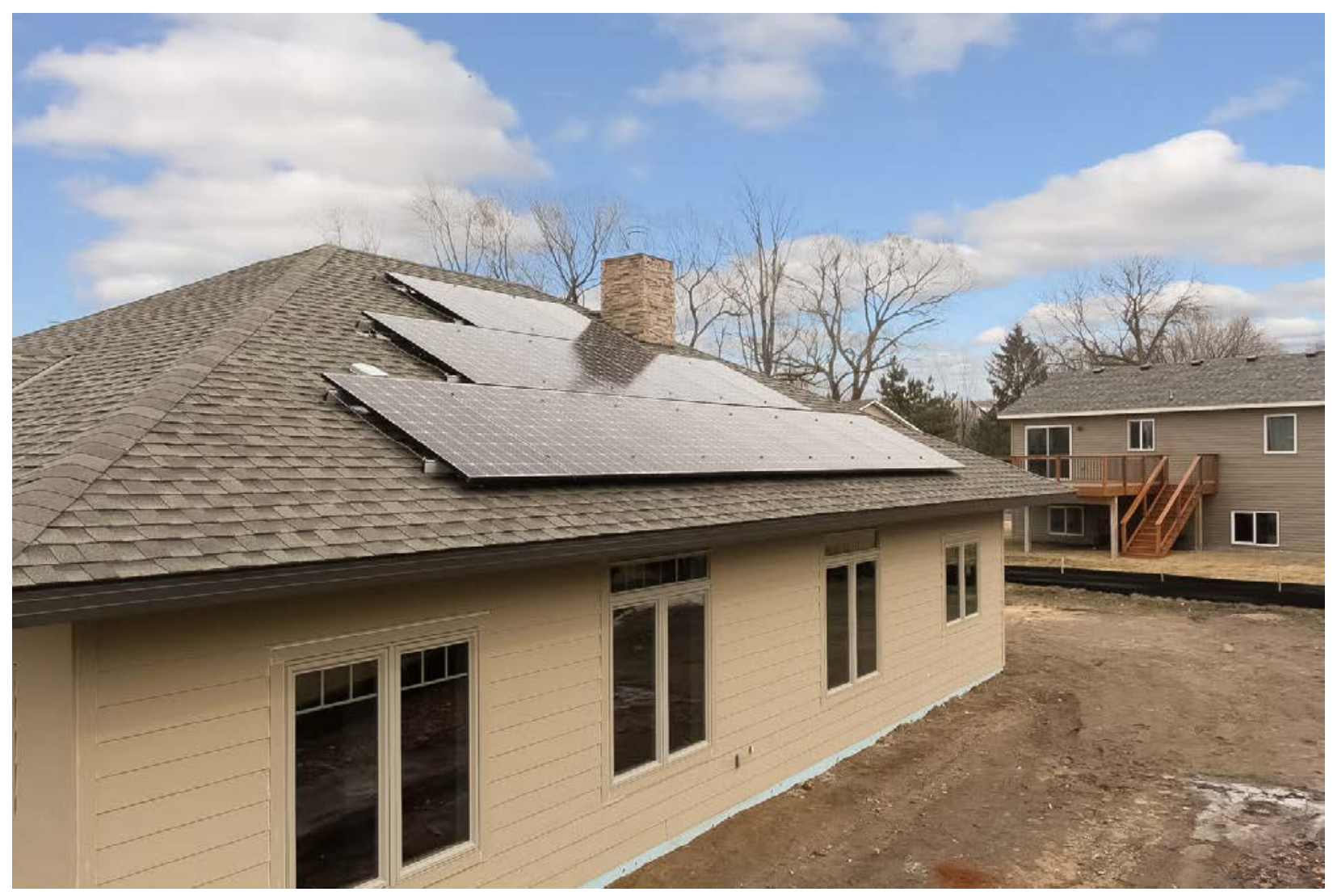

Figure 12. Amaris Custom Homes: Rear elevation with solar panels of the Vadnais Heights, Minnesota, project

This report is available at no cost from the National Renewable Energy Laboratory (NREL) at www.nrel.gov/publications. 


\subsubsection{Technical Characteristics of Typical Construction Practices and DOE ZERH Solutions}

The typical construction practices of Amaris Custom Homes are close to the ZERH requirements.

Table 3. Amaris Custom Homes: Vadnais Heights, Minnesota, Project

\begin{tabular}{|c|c|c|}
\hline Measure & Typical Construction Practices & ZERH Solution \\
\hline Infiltration & $1.00 \mathrm{ACH} 50$ & $1.64 \mathrm{ACH} 50$ \\
\hline Cooling Equipment & 14 SEER & 14.5 SEER \\
\hline Heating Equipment & Natural gas, 96 AFUE & $\begin{array}{l}\text { Natural gas combination boiler, } \\
95 \% \text { efficient }\end{array}$ \\
\hline Water Heater & Natural gas, $0.90 \mathrm{EF}$ & $\begin{array}{c}\text { Natural gas combination boiler, } \\
95 \% \text { efficient }\end{array}$ \\
\hline Lighting & 50\% ENERGY STAR & 100\% ENERGY STAR LED \\
\hline Thermostat & Programmable & Programmable \\
\hline Dishwasher & ENERGY STAR rated & ENERGY STAR rated \\
\hline Refrigerator & ENERGY STAR rated & ENERGY STAR rated \\
\hline Clothes Washer & ENERGY STAR rated & ENERGY STAR rated \\
\hline Ceiling Insulation & $\begin{array}{c}\text { 2-in. closed-cell spray foam on lid } \\
\text { with R-48 blown fiberglass. } \\
\text { Total R-65.5 }\end{array}$ & $\begin{array}{c}\text { 2-in. closed-cell spray foam on lid } \\
\text { with R-48 blown fiberglass. } \\
\text { Total R-65.5 }\end{array}$ \\
\hline $\begin{array}{c}\text { Above-Grade Wall } \\
\text { Insulation }\end{array}$ & $\begin{array}{l}\text { R-5 continuous exterior } \\
\text { insulation, 3-in. closed-cell spray } \\
\text { foam in cavity. Total R-24.5 }\end{array}$ & $\begin{array}{l}\mathrm{R}-5 \text { continuous exterior } \\
\text { insulation, } 3 \text {-in. closed-cell spray } \\
\text { foam in cavity. Total R-24.5 }\end{array}$ \\
\hline Foundation Insulation & $\mathrm{R}-10$ & Under slab R-10 \\
\hline Windows & $\begin{array}{l}\text { Double-pane, argon-filled; } \\
\text { PVC-framed; Low-e windows } \\
\text { with U- } 0.25\end{array}$ & $\begin{array}{l}\text { Double-pane, argon-filled; } \\
\text { PVC-framed; Low-e windows } \\
\text { with U-0.25 and } 0.16 \text { SHGC }\end{array}$ \\
\hline $\begin{array}{l}\text { Reduced Lumber from } \\
\text { Advanced Framing }\end{array}$ & $\begin{array}{c}2 \text { x 6-in. walls } 24 \text {-in. on center, } \\
\text { open corners and single-ply } \\
\text { headers }\end{array}$ & $\begin{array}{c}2 \text { x 6-in. walls } 24 \text {-in. on center, } \\
\text { open corners and single-ply } \\
\text { headers }\end{array}$ \\
\hline Ventilation & HRV & HRV \\
\hline Duct Systems & $\begin{array}{l}\text { Located within the thermal and } \\
\text { air barrier, fully ducted, sealed } \\
\text { with mastic }\end{array}$ & $\begin{array}{l}\text { Located within the thermal and } \\
\text { air barrier, fully ducted, sealed } \\
\text { with mastic }\end{array}$ \\
\hline
\end{tabular}




\subsubsection{Energy Modeling}

Figure 13 shows the energy modeling results for Amaris' Homes Vadnais Heights, Minnesota, project. Predictions of site energy use differed between the two models: $85 \mathrm{MMBtu} / \mathrm{yr}$ for BEopt and $71 \mathrm{MMBtu} / \mathrm{yr}$ REM/Rate. This may be because the actual house geometry, which includes significant portions of the plan that do not intersect at right angles, could not be modeled correctly in BEopt. In addition, window type varied not only by orientation (which can be accommodated in BEopt) but also within each orientation. BEopt inputs and HERS information can be found in Appendix E and Appendix F.

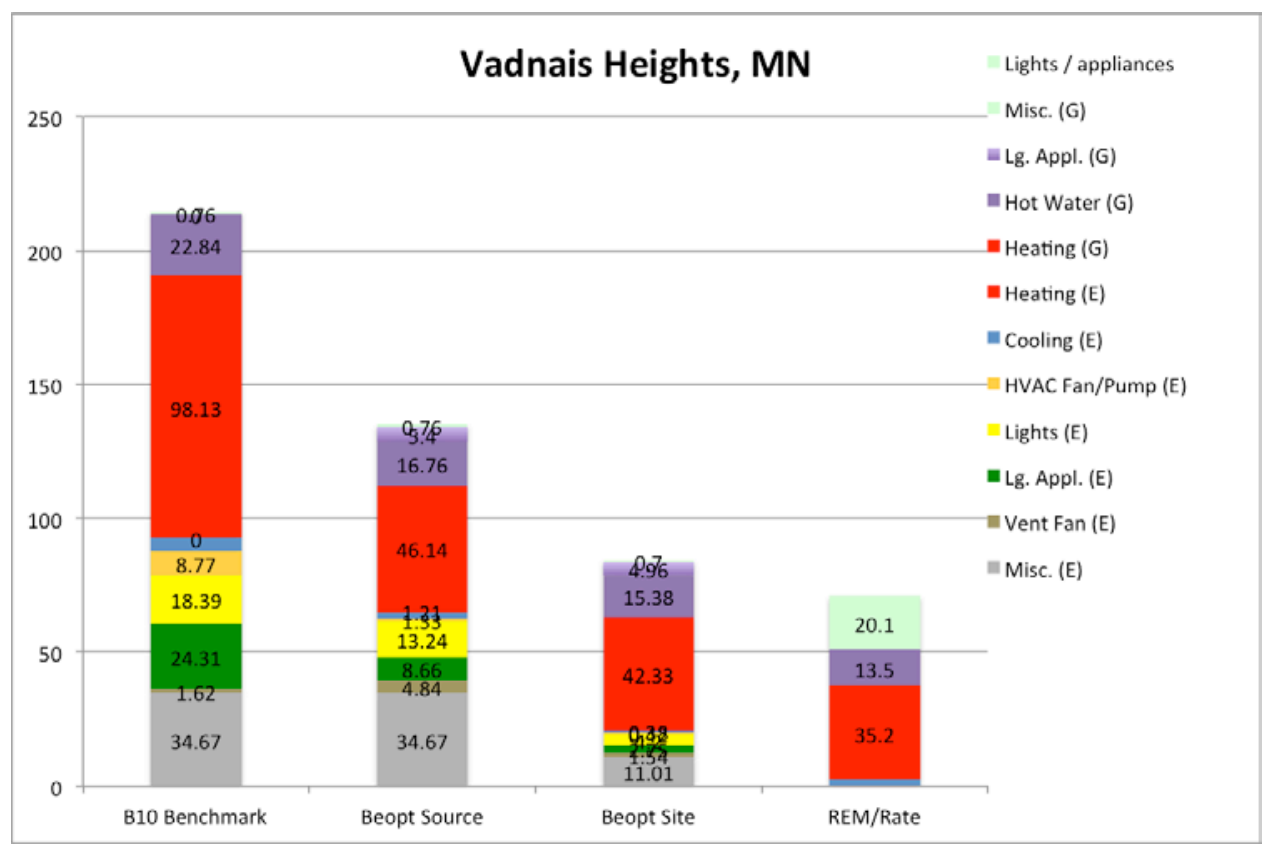

Figure 13. Amaris Custom Homes: Energy modeling results for the Vadnais Heights, Minnesota, project 


\subsection{Amaris Custom Homes: Apple Valley, Minnesota, Project}

\subsubsection{Basic Project Information}

This 3,716- $\mathrm{ft}^{2}$, 4-bedroom, $3 \frac{1}{2}$-bathroom, 1-story home with finished basement is located in Climate Zone 6. Lot orientation precluded additional solar panels to achieve full ZERH for the home.

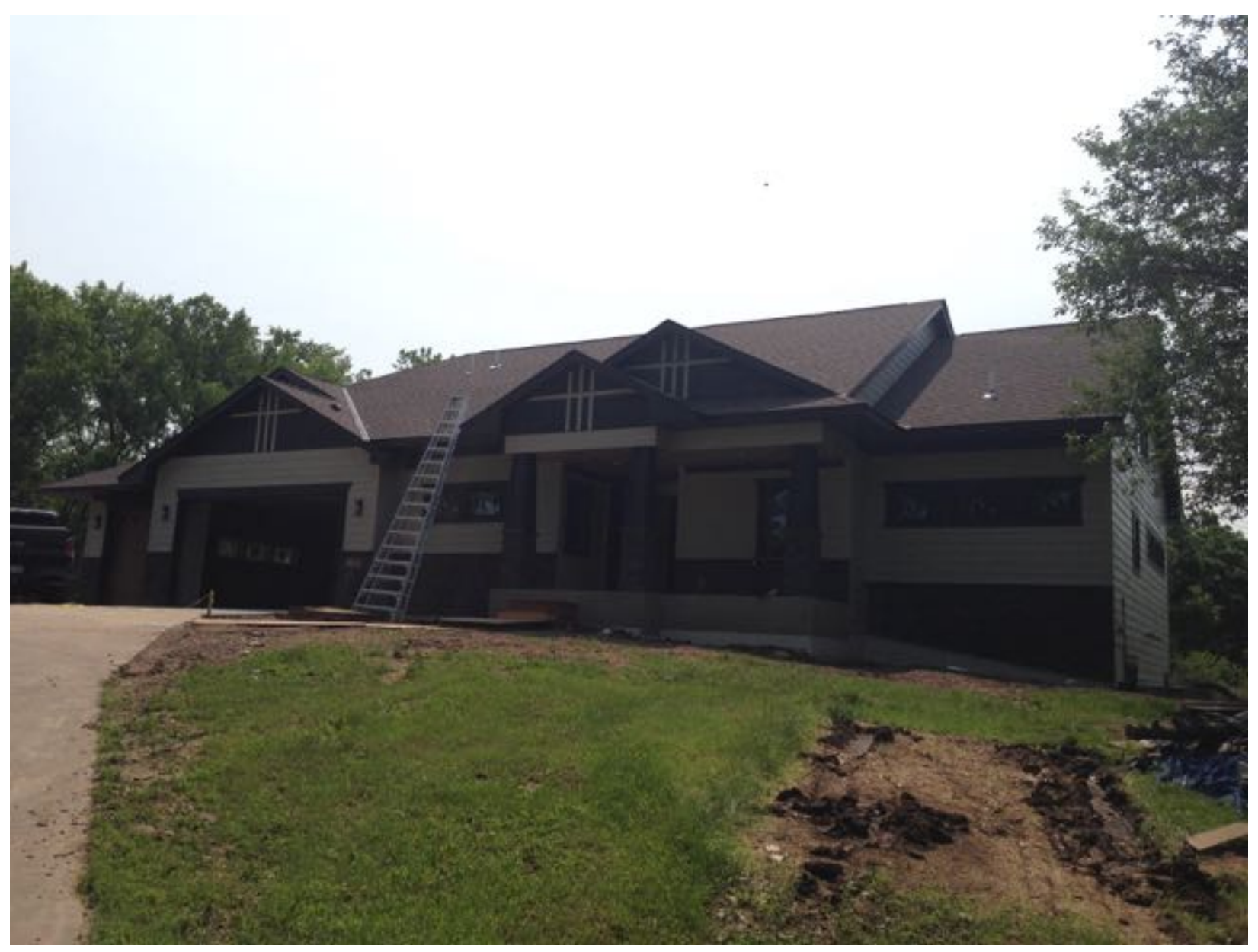

Figure 14. Amaris Custom Homes: Front elevation of the Apple Valley, Minnesota, project 


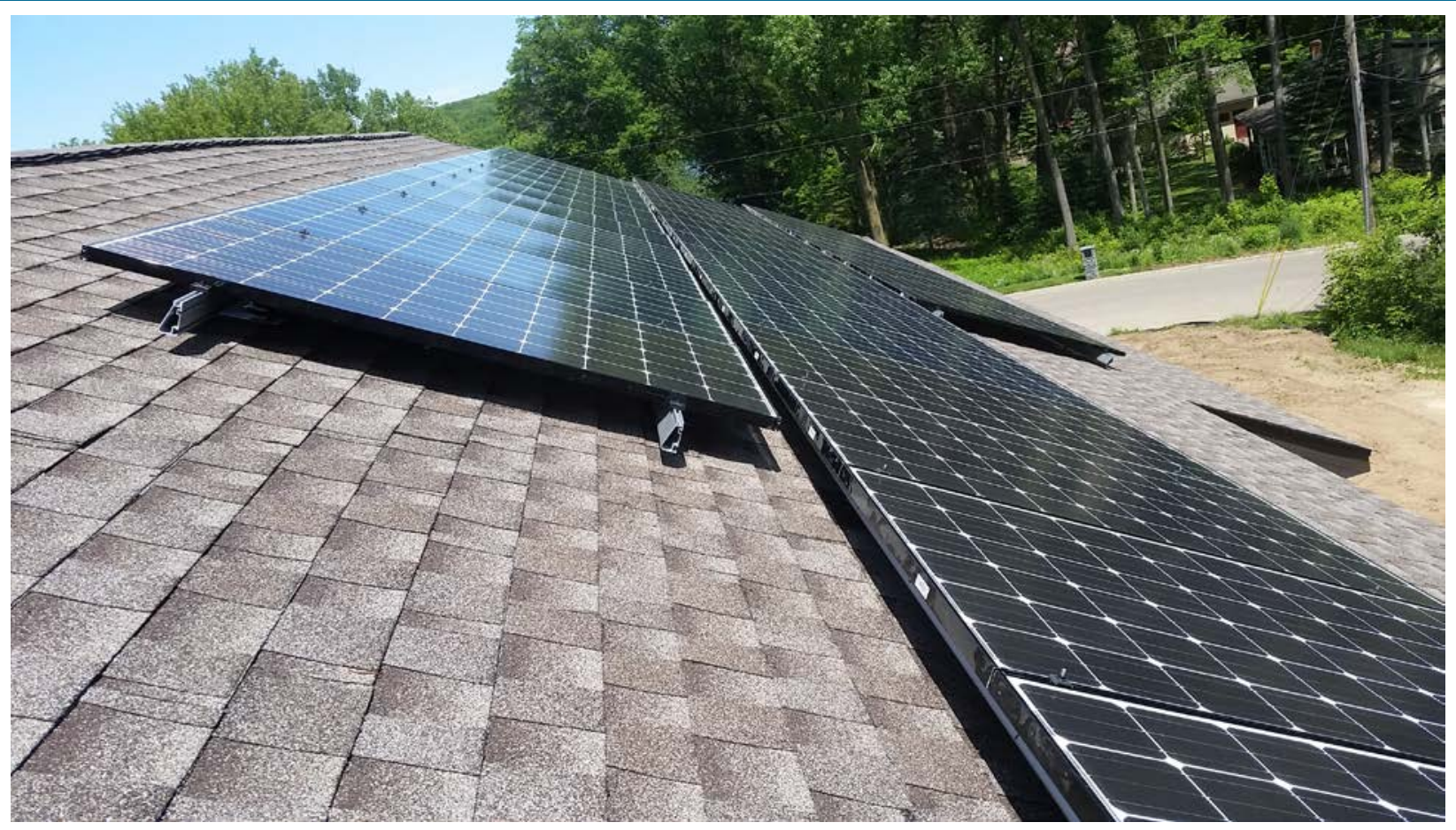

Figure 15. Amaris Custom Homes: Roof with solar panels of the Apple Valley, Minnesota, project

This report is available at no cost from the National Renewable Energy Laboratory (NREL) at www.nrel.gov/publications. 


\subsubsection{Technical Characteristics of Typical Construction Practices and DOE ZERH Solutions}

The typical construction practices of Amaris Custom Homes are close to the ZERH requirements.

Table 4. Amaris Custom Homes: Apple Valley, Minnesota, Project

\begin{tabular}{|c|c|c|}
\hline Measure & Typical Construction Practices & ZERH Solution \\
\hline Infiltration & $1.00 \mathrm{ACH} 50$ & $0.66 \mathrm{ACH} 50$ \\
\hline Cooling Equipment & 14 SEER & 14.5 SEER \\
\hline Heating Equipment & Natural gas, 96 AFUE & Natural gas, 98 AFUE \\
\hline Water Heater & Natural gas, $0.90 \mathrm{EF}$ & Electric, $0.91 \mathrm{EF}$ \\
\hline Lighting & $50 \%$ ENERGY STAR & $100 \%$ ENERGY STAR \\
\hline Thermostat & Programmable & Programmable \\
\hline Dishwasher & ENERGY STAR rated & ENERGY STAR rated \\
\hline Refrigerator & ENERGY STAR rated & ENERGY STAR rated \\
\hline Clothes Washer & ENERGY STAR rated & ENERGY STAR rated \\
\hline Ceiling Insulation & $\begin{array}{c}\text { 2-in. closed-cell spray foam on lid } \\
\text { with R-48 blown fiberglass. } \\
\text { Total R-65.5 }\end{array}$ & $\begin{array}{c}\text { 2-in. closed-cell spray foam on lid } \\
\text { with R-48 blown fiberglass. } \\
\text { Total R-65.5 }\end{array}$ \\
\hline $\begin{array}{c}\text { Above-Grade Wall } \\
\text { Insulation }\end{array}$ & $\begin{array}{l}\text { R-5 continuous exterior } \\
\text { insulation, } 3 \text {-in. closed-cell spray } \\
\text { foam in cavity. Total R-24.5 }\end{array}$ & $\begin{array}{l}\mathrm{R}-5 \text { continuous exterior } \\
\text { insulation, } 3 \text {-in. closed-cell spray } \\
\text { foam in cavity. Total R-25 }\end{array}$ \\
\hline Foundation Insulation & $\mathrm{R}-10$ & Under Slab R-10 \\
\hline Windows & $\begin{array}{l}\text { Double-pane, argon-filled; } \\
\text { PVC-framed; Low-e windows } \\
\text { with U- } 0.25\end{array}$ & $\begin{array}{l}\text { Double-pane, argon-filled; } \\
\text { PVC-framed; Low-e windows } \\
\text { with U- } 0.26 \text { and } 0.18 \text { SHGC }\end{array}$ \\
\hline $\begin{array}{l}\text { Reduced Lumber from } \\
\text { Advanced Framing }\end{array}$ & $\begin{array}{c}2 \times 6 \text {-in. walls } 24 \text {-in. on center, } \\
\text { open corners and single-ply } \\
\text { headers }\end{array}$ & $\begin{array}{c}2 \times 6 \text {-in. walls } 24 \text {-in. on center, } \\
\text { open corners and single-ply } \\
\text { headers }\end{array}$ \\
\hline Ventilation & HRV & HRV \\
\hline Duct Systems & $\begin{array}{l}\text { Located within the thermal and } \\
\text { air barrier, fully ducted, sealed } \\
\text { with mastic }\end{array}$ & $\begin{array}{l}\text { Located within the thermal and } \\
\text { air barrier, fully ducted, sealed } \\
\text { with mastic }\end{array}$ \\
\hline
\end{tabular}




\subsubsection{Energy Modeling}

Figure 16 shows the energy modeling results for Amaris Custom Homes' Apple Valley project. Predictions of site energy use were closely aligned between the two models: $110 \mathrm{MMBtu} / \mathrm{yr}$ for BEopt and $115 \mathrm{MMBtu} / \mathrm{yr}$ REM/Rate. Models were also closely aligned in predictions of PV production: $54 \mathrm{MMBtu} / \mathrm{yr}$ and $54 \mathrm{MMBtu} / \mathrm{yr}$, respectively. BEopt inputs and HERS information can be found in Appendix G and Appendix $\mathrm{H}$.

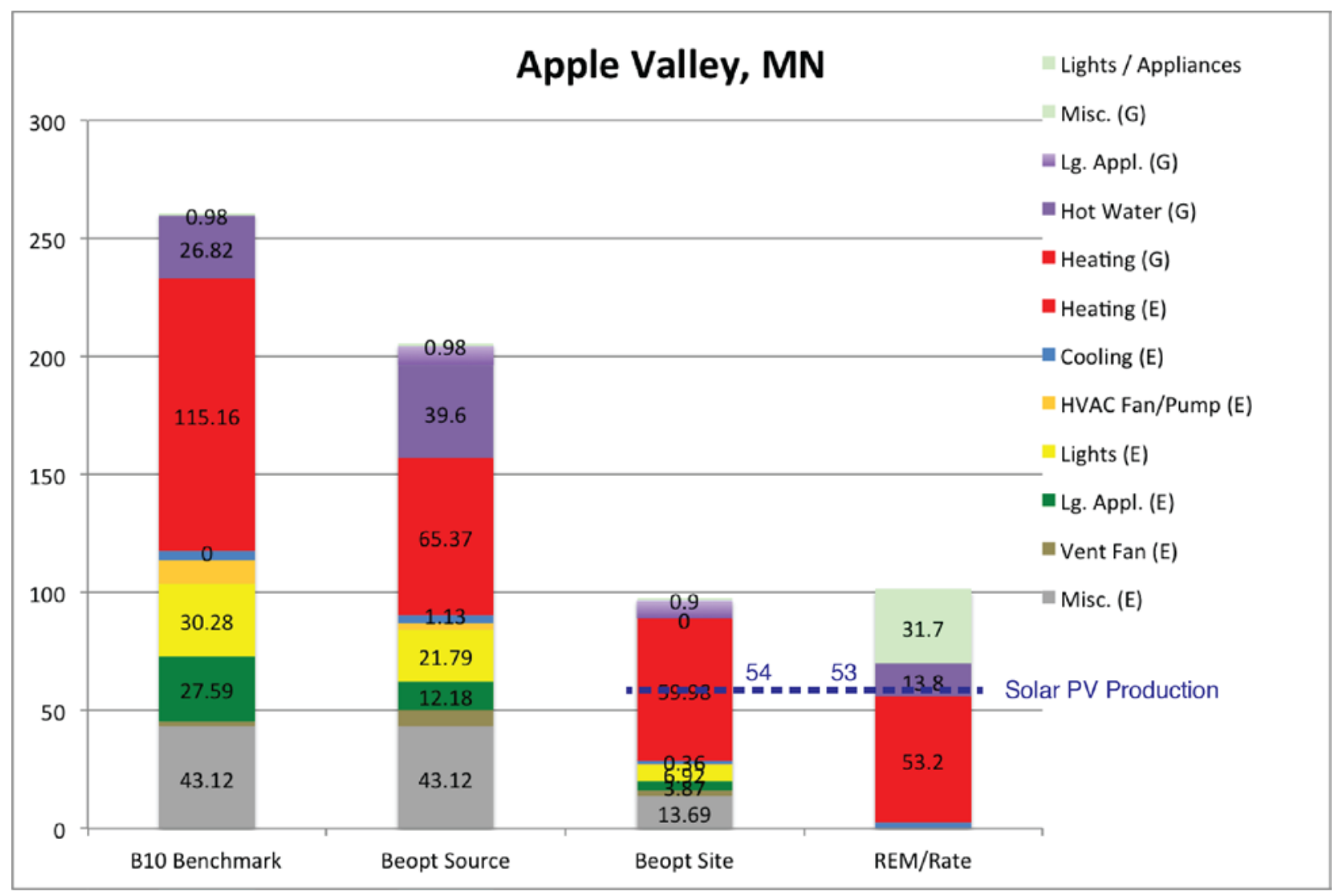

Figure 16. Amaris Custom Homes: Energy modeling results for the Apple Valley, Minnesota, project 


\subsection{Amaris Custom Homes: White Bear Township, Minnesota, Project}

\subsubsection{Basic Project Information}

This 1,654- $\mathrm{ft}^{2}$, 3-bedroom, 2-bathroom, 1-story home with conditioned crawl space is located in Climate Zone 6 .

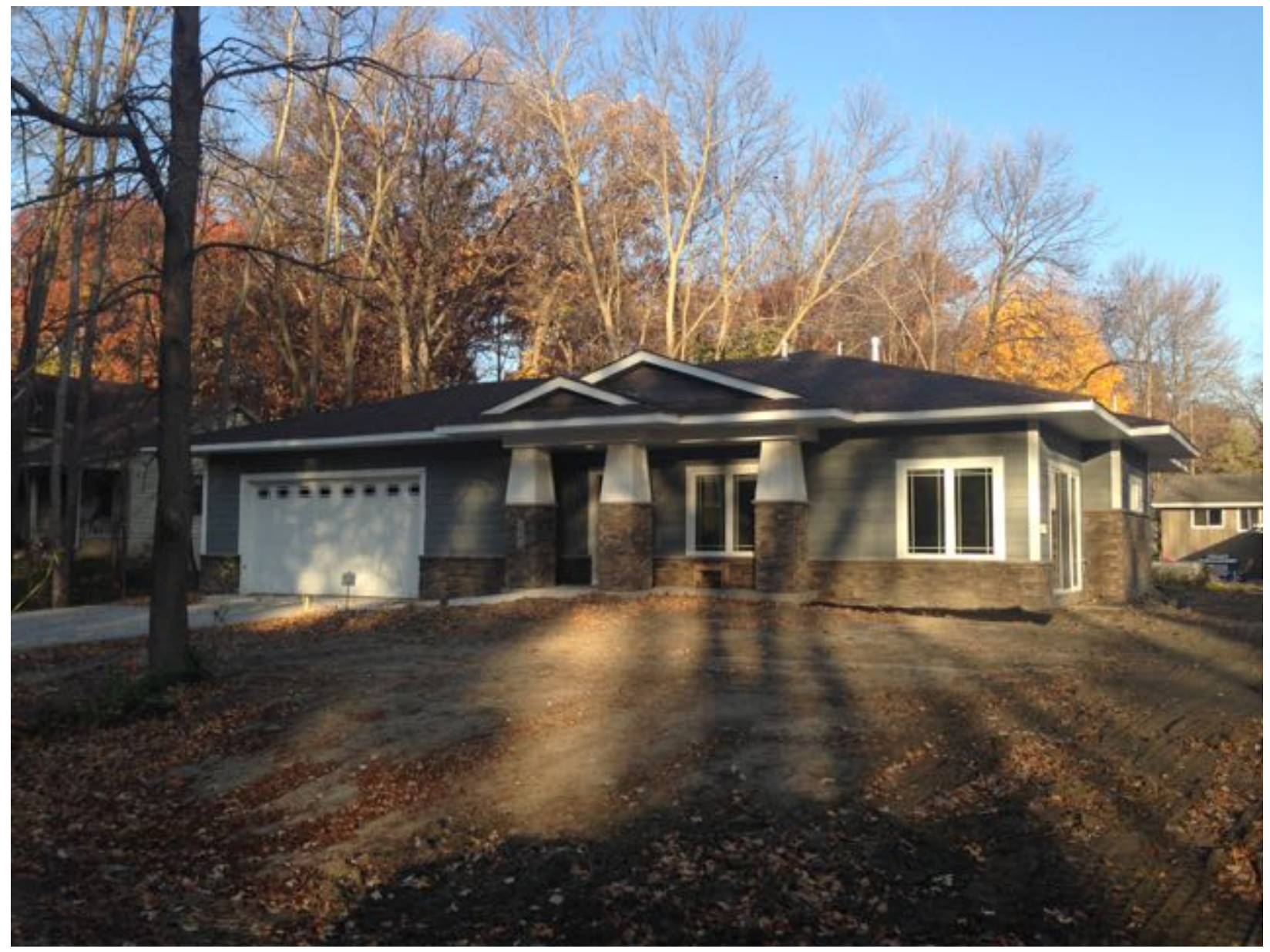

Figure 17. Amaris Custom Homes: Front elevation of the White Bear Township, Minnesota, project 


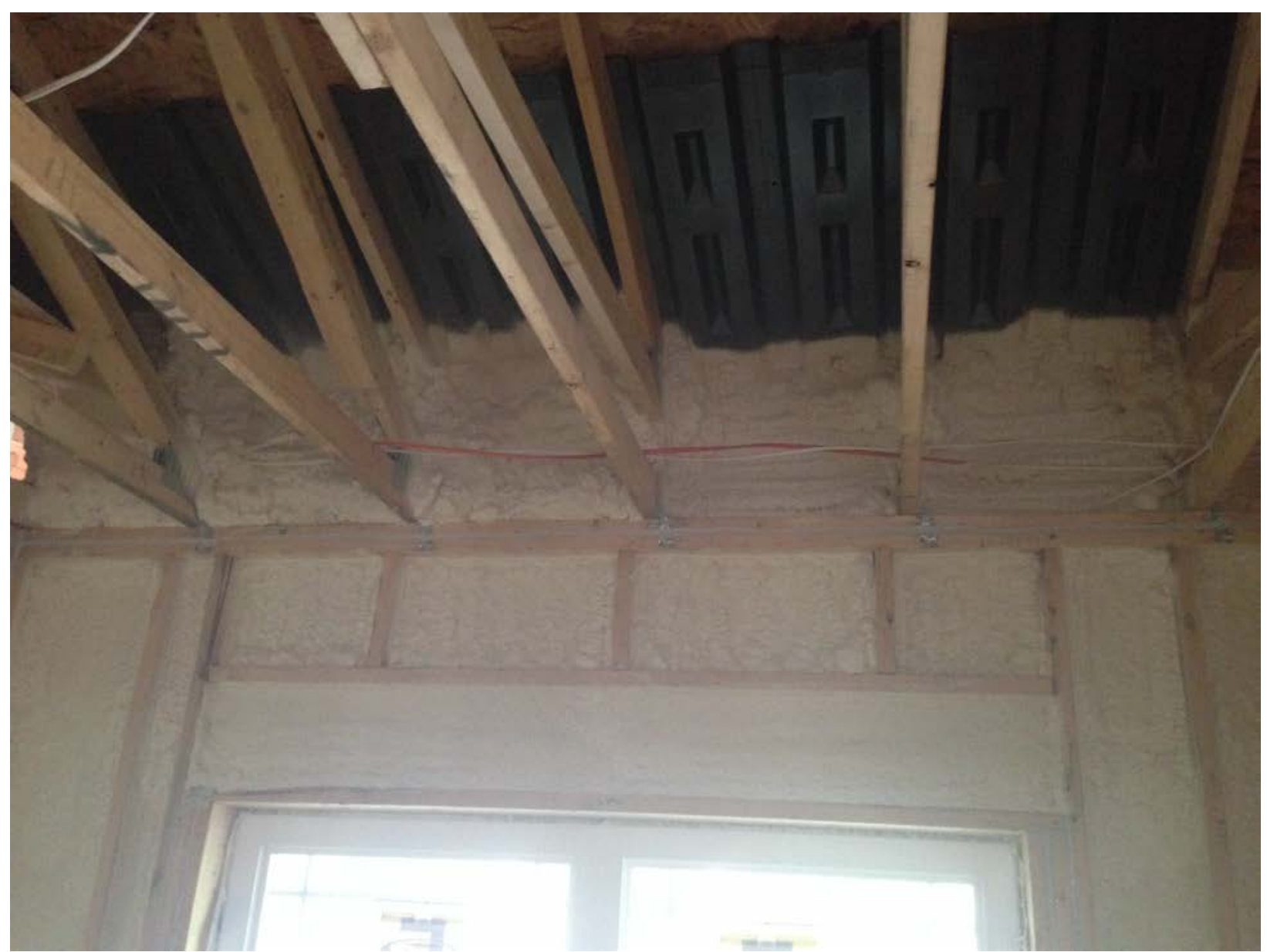

Figure 18. Amaris Custom Homes: Spray foam walls and energy heel truss of the White Bear Township, Minnesota, project 


\subsubsection{Technical Characteristics of Typical Construction Practices and DOE ZERH Solutions}

The typical construction practices of Amaris Custom Homes are close to the ZERH requirements. This home could not be certified under the DOE ZERH program. The builder requires the credentialing of the HVAC contractor as part of the project specifications, and it reviews that requirement at the time of the contract bid and award. This requirement was also reviewed at the required pre-construction meeting; however, despite assurances from the HVAC contractor, the qualification was not achieved until after the project was completed. This home meets all other criteria of the DEO ZERH program.

Table 5. Amaris Custom Homes: White Bear Township, Minnesota, Project

\begin{tabular}{|c|c|c|}
\hline Measure & Typical Construction Practices & ZERH Solution \\
\hline Infiltration & $1.00 \mathrm{ACH} 50$ & $0.91 \mathrm{ACH} 50$ \\
\hline Cooling Equipment & 14 SEER & 14.5 SEER \\
\hline Heating Equipment & Natural gas, 96 AFUE & Natural gas, 96 AFUE \\
\hline Water Heater & Natural gas, $0.90 \mathrm{EF}$ & Natural gas, $0.80 \mathrm{EF}$ \\
\hline Lighting & $50 \%$ ENERGY STAR & 79\% ENERGY STAR \\
\hline Thermostat & Programmable & Programmable \\
\hline Dishwasher & ENERGY STAR rated & ENERGY STAR rated \\
\hline Refrigerator & ENERGY STAR rated & ENERGY STAR rated \\
\hline Clothes Washer & ENERGY STAR rated & ENERGY STAR rated \\
\hline Ceiling Insulation & $\begin{array}{c}\text { 2-in. closed-cell spray foam on lid } \\
\text { with R-48 blown fiberglass. } \\
\text { Total R-65.5 }\end{array}$ & $\begin{array}{c}\text { 2-in. closed-cell spray foam on lid } \\
\text { with R-48 blown fiberglass. } \\
\text { Total R-65.5 }\end{array}$ \\
\hline $\begin{array}{c}\text { Above-Grade Wall } \\
\text { Insulation }\end{array}$ & $\begin{array}{l}\mathrm{R}-5 \text { continuous exterior } \\
\text { insulation, } 3 \text {-in. closed-cell spray } \\
\text { foam in cavity. Total R-25 }\end{array}$ & $\begin{array}{l}\text { R-5 continuous exterior } \\
\text { insulation, } 3 \text {-in. closed-cell spray } \\
\text { foam in cavity. Total R-25 }\end{array}$ \\
\hline Foundation Insulation & $\mathrm{R}-10$ & $\mathrm{R}-10$ \\
\hline Windows & $\begin{array}{l}\text { Double-pane, argon-filled; } \\
\text { PVC-framed; Low-e windows } \\
\text { with U- } 0.25\end{array}$ & $\begin{array}{l}\text { Double-pane, argon-filled; } \\
\text { PVC-framed; Low-e windows } \\
\text { with U-0.25 and } 0.16 \text { SHGC }\end{array}$ \\
\hline $\begin{array}{l}\text { Reduced Lumber from } \\
\text { Advanced Framing }\end{array}$ & $\begin{array}{c}2 \text { x 6-in. walls } 24 \text {-in. on center, } \\
\text { open corners and single-ply } \\
\text { headers }\end{array}$ & $\begin{array}{c}2 \times 6 \text {-in. walls } 24 \text {-in. on center, } \\
\text { open corners and single-ply } \\
\text { headers }\end{array}$ \\
\hline Ventilation & HRV & HRV \\
\hline Duct Systems & $\begin{array}{l}\text { Located within the thermal and } \\
\text { air barrier, fully ducted, sealed } \\
\text { with mastic }\end{array}$ & $\begin{array}{l}\text { Located within the thermal and } \\
\text { air barrier, fully ducted, sealed } \\
\text { with mastic }\end{array}$ \\
\hline
\end{tabular}




\subsubsection{Energy Modeling}

Figure 19 shows the energy modeling results for Amaris Custom Homes' White Bear Township, Minnesota, project. Predictions of site energy use were nearly identical between the two models: $76 \mathrm{MMBtu} / \mathrm{yr}$ for BEopt and $77 \mathrm{MMBtu} / \mathrm{yr}$ REM/Rate. BEopt inputs and HERS information can be found in Appendix I and Appendix J.

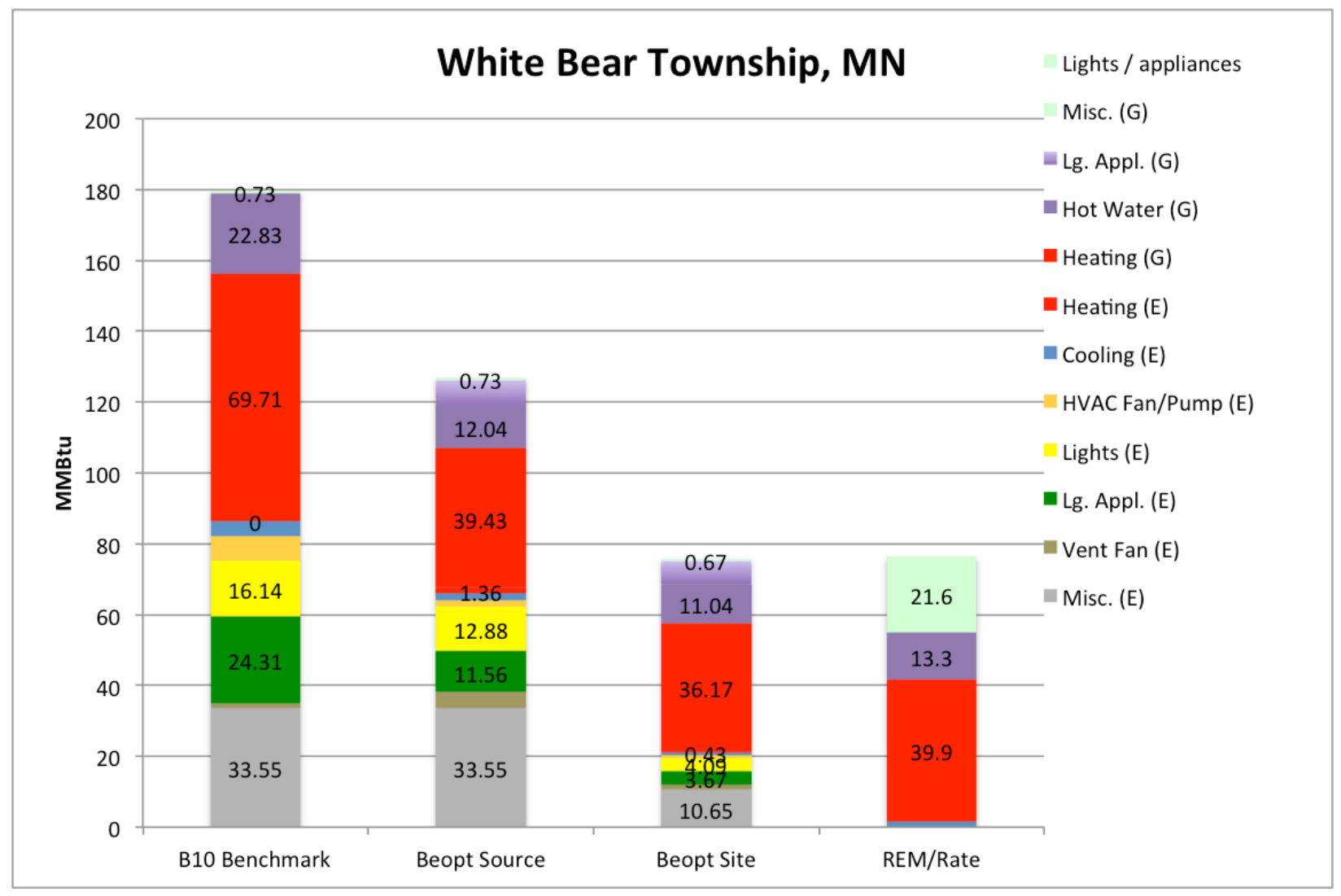

Figure 19. Amaris Custom Homes: Energy modeling results for the White Bear Township, Minnesota, project 


\subsection{Amaris Custom Homes: Mound, Minnesota, Project}

\subsubsection{Basic Project Information}

This 3,537-ft ${ }^{2}$, 4-bedroom, 31/2-bathroom, 1-story home with finished basement is located in Climate Zone 6.

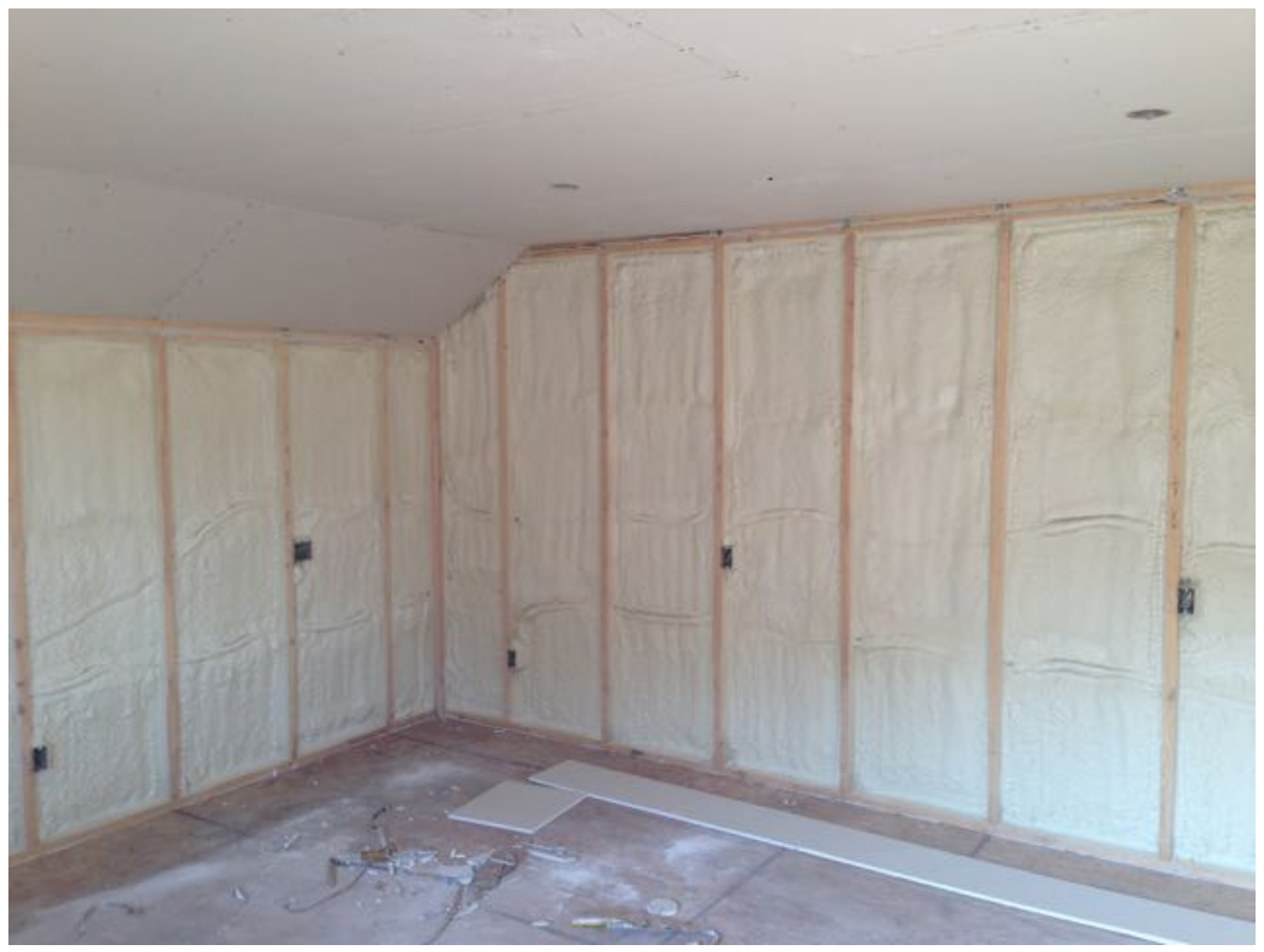

Figure 20. Amaris Custom Homes: Advanced frame wall with spray foam insulation of the Mound, Minnesota, project 


\subsubsection{Technical Characteristics of Typical Construction Practices and DOE ZERH Solutions}

The typical construction practices of Amaris Custom Homes are close to the ZERH requirements. This home could not be certified under the DOE ZERH program. The builder requires the credentialing of the HVAC contractor as part of the project specifications, and it reviews that requirement at the time of the contract bid and award. This requirement was also reviewed at the required pre-construction meeting; however, despite assurances from the HVAC contractor, the qualification was not achieved until after the project was completed. This home meets all other criteria of the DEO ZERH program.

Table 6. Amaris Custom Homes: Mound, Minnesota, Project

\begin{tabular}{|c|c|c|}
\hline Measure & Typical Construction Practices & ZERH Solution \\
\hline Infiltration & $1.00 \mathrm{ACH} 50$ & $1.58 \mathrm{ACH} 50$ \\
\hline Cooling Equipment & 14 SEER & 14.5 SEER \\
\hline Heating Equipment & Natural gas, 96 AFUE & Natural gas, 95 AFUE \\
\hline Water Heater & Natural gas, 0.90 EF & Natural gas, 0.80 EF \\
\hline Lighting & 50\% ENERGY STAR & $100 \%$ ENERGY STAR \\
\hline Thermostat & Programmable & Programmable \\
\hline Dishwasher & ENERGY STAR rated & ENERGY STAR rated \\
\hline Refrigerator & ENERGY STAR rated & ENERGY STAR rated \\
\hline Clothes Washer & ENERGY STAR rated & ENERGY STAR rated \\
\hline Ceiling Insulation & $\begin{array}{c}\text { 2-in. closed-cell spray foam on lid } \\
\text { with R-48 blown fiberglass. } \\
\text { Total R-65.5 }\end{array}$ & R-49 blown fiberglass \\
\hline $\begin{array}{c}\text { Above-Grade Wall } \\
\text { Insulation }\end{array}$ & $\begin{array}{l}\text { R-5 continuous exterior } \\
\text { insulation, } 3 \text {-in. closed-cell spray } \\
\text { foam in cavity. Total R-25 }\end{array}$ & $\begin{array}{l}\text { R-5 continuous exterior } \\
\text { insulation, } 3 \text {-in. closed-cell spray } \\
\text { foam in cavity. Total R-25 }\end{array}$ \\
\hline Foundation Insulation & $\mathrm{R}-10$ & R-29.5 \\
\hline Windows & $\begin{array}{l}\text { Double-pane, argon-filled; } \\
\text { PVC-framed; Low-e windows } \\
\text { with U-0.25 }\end{array}$ & $\begin{array}{l}\text { Double-pane, argon-filled; } \\
\text { PVC-framed; Low-e windows } \\
\text { with U-0.28 and } 0.29 \text { SHGC }\end{array}$ \\
\hline $\begin{array}{l}\text { Reduced Lumber from } \\
\text { Advanced Framing }\end{array}$ & $\begin{array}{l}2 \text { x 6-in. walls } 24 \text {-in. on center, } \\
\text { open corners and single-ply } \\
\text { headers }\end{array}$ & $\begin{array}{c}2 \text { x 6-in. walls } 24 \text {-in. on center, } \\
\text { open corners and single-ply } \\
\text { headers }\end{array}$ \\
\hline Ventilation & HRV & HRV \\
\hline Duct Systems & $\begin{array}{l}\text { Located within the thermal and } \\
\text { air barrier, fully ducted, sealed } \\
\text { with mastic }\end{array}$ & $\begin{array}{l}\text { Located within the thermal and } \\
\text { air barrier, fully ducted, sealed } \\
\text { with mastic }\end{array}$ \\
\hline
\end{tabular}




\subsubsection{Energy Modeling}

Figure 21 shows the energy modeling results for Amaris Custom Homes' Mound, Minnesota, project. Predictions of site energy use differed significantly between the two models: 115 $\mathrm{MMBtu} / \mathrm{yr}$ for BEopt and $106 \mathrm{MMBtu} / \mathrm{yr} \mathrm{REM} / \mathrm{Rate}$. It appears that differences in predicted heating energy use were largely responsible for this. This house included plan features that produced errors in the BEopt simulation due to an inability to resolve the roof. The file was sent to the BEopt development team, which modified the geometry to enable the model to run. In addition, the house includes a partial second story under a complex roof shape that could not be correctly modeled in BEopt. This resulted in significant additional exterior wall surface that is not present in the actual design or the REM/Rate model. BEopt inputs and HERS information can be found in Appendix K and Appendix L.

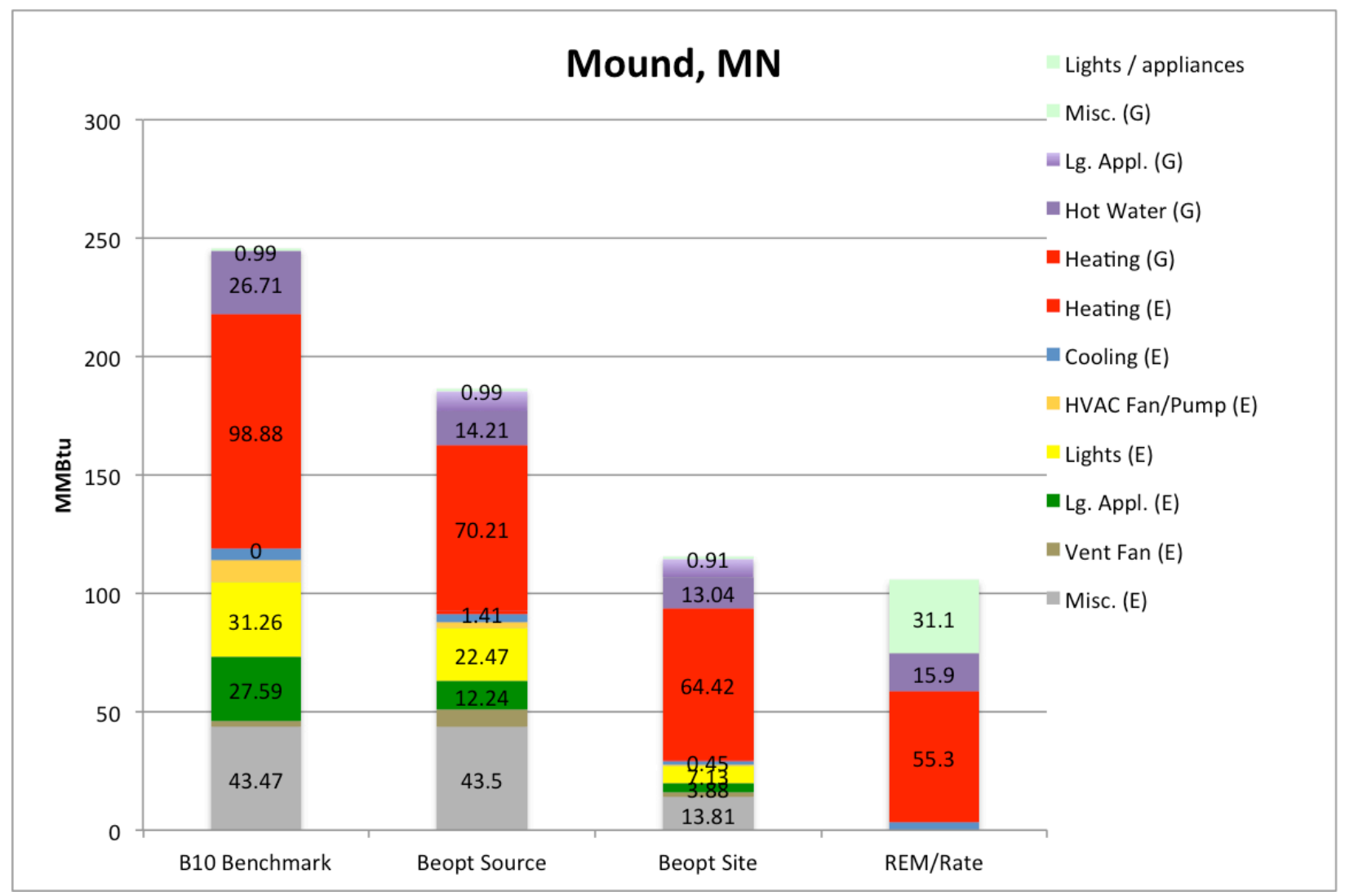

Figure 21. Amaris Custom Homes: Energy modeling results for the Mound, Minnesota, project 


\subsection{Amaris Custom Homes: Stillwater, Minnesota, Project}

\subsubsection{Basic Project Information}

This 2,927-ft2, 4-bedroom, 21/2-bathroom, 2-story home with conditioned basement is located in Climate Zone 6.

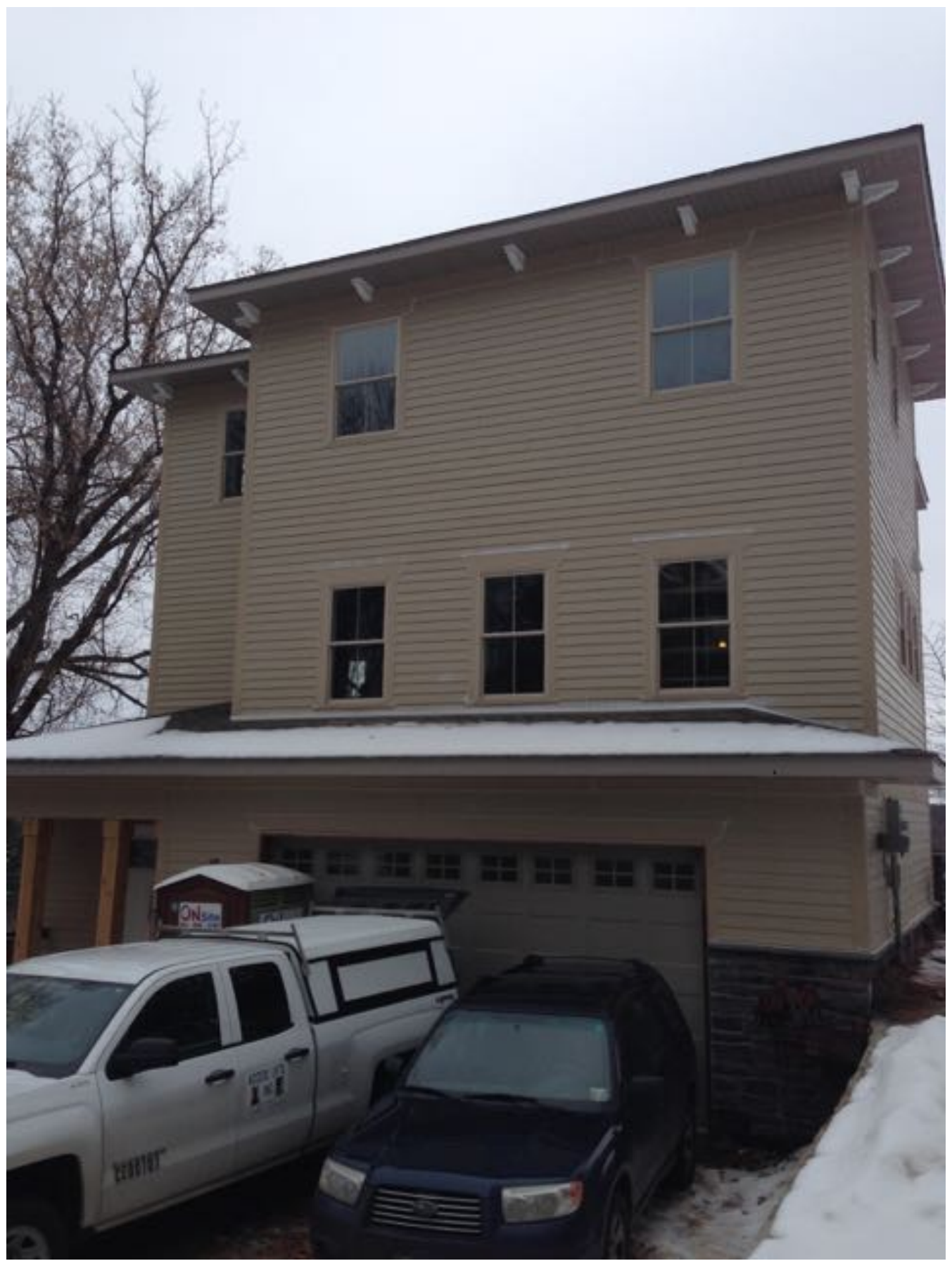

Figure 22. Amaris Custom Homes: Front elevation of the Stillwater, Minnesota, project 


\subsubsection{Technical Characteristics of Typical Construction Practices and DOE ZERH Solutions}

The typical construction practices of Amaris Custom Homes are close to the ZERH requirements.

Table 7. Amaris Custom Homes: Stillwater, Minnesota, Project

\begin{tabular}{|c|c|c|}
\hline Measure & Typical Construction Practices & ZERH Solution \\
\hline Infiltration & $1.00 \mathrm{ACH} 50$ & $1.87 \mathrm{ACH} 50$ \\
\hline Cooling Equipment & 14 SEER & 15.0 SEER \\
\hline Heating Equipment & Natural gas, 96 AFUE & Natural gas, 96 AFUE \\
\hline Water Heater & Natural gas, $0.90 \mathrm{EF}$ & Natural gas, 0.70 EF \\
\hline Lighting & 50\% ENERGY STAR & 90\% ENERGY STAR \\
\hline Thermostat & Programmable & Programmable \\
\hline Dishwasher & ENERGY STAR rated & ENERGY STAR rated \\
\hline Refrigerator & ENERGY STAR rated & ENERGY STAR rated \\
\hline Clothes Washer & ENERGY STAR rated & ENERGY STAR rated \\
\hline Ceiling Insulation & $\begin{array}{c}\text { 2-in. closed-cell spray foam on lid } \\
\text { with R-48 blown fiberglass. } \\
\text { Total R-65.5 }\end{array}$ & $\begin{array}{c}\text { 2-in. closed-cell spray foam on lid } \\
\text { with R-48 blown fiberglass. } \\
\text { Total R-65.5 }\end{array}$ \\
\hline $\begin{array}{c}\text { Above-Grade Wall } \\
\text { Insulation }\end{array}$ & $\begin{array}{l}\text { R-5 continuous exterior } \\
\text { insulation, } 3 \text {-in. closed-cell spray } \\
\text { foam in cavity. Total R-24.5 }\end{array}$ & $\begin{array}{l}\mathrm{R}-5 \text { continuous exterior } \\
\text { insulation, } 3 \text {-in. closed-cell spray } \\
\text { foam in cavity. Total R-24.5 }\end{array}$ \\
\hline Foundation Insulation & $\mathrm{R}-10$ & $\mathrm{R}-10$ \\
\hline Windows & $\begin{array}{c}\text { Double-pane, argon-filled; | } \\
\text { PVC-framed; Low-e windows } \\
\text { with U- } 0.25\end{array}$ & $\begin{array}{l}\text { Double-pane, argon-filled; } \\
\text { PVC-framed; Low-e windows } \\
\text { with U-0.30 and } 0.25 \text { SHGC }\end{array}$ \\
\hline $\begin{array}{l}\text { Reduced Lumber from } \\
\text { Advanced Framing }\end{array}$ & $\begin{array}{c}2 \times 6 \text {-in. walls } 24 \text {-in. on center, } \\
\text { open corners and single-ply } \\
\text { headers }\end{array}$ & $\begin{array}{c}2 \times 6 \text {-in. walls } 24 \text {-in. on center, } \\
\text { open corners and single-ply } \\
\text { headers }\end{array}$ \\
\hline Ventilation & HRV & HRV \\
\hline Duct Systems & $\begin{array}{l}\text { Located within the thermal and } \\
\text { air barrier, fully ducted, sealed } \\
\text { with mastic }\end{array}$ & $\begin{array}{l}\text { Located within the thermal and } \\
\text { air barrier, fully ducted, sealed } \\
\text { with mastic }\end{array}$ \\
\hline
\end{tabular}




\subsubsection{Energy Modeling}

Figure 23 shows the energy modeling results for Amaris Custom Homes' Stillwater, Minnesota, project. Predictions of site energy use differed significantly between the two models: 136 $\mathrm{MMBtu} / \mathrm{yr}$ for BEopt and $115 \mathrm{MMBtu} / \mathrm{yr} \mathrm{REM} / \mathrm{Rate}$. It appears that differences in predicted heating energy use were largely responsible for this. This house included design features that could not be modeled in BEopt. Most significantly, the design includes a walk-out basement. Therefore, the BEopt model included more above-grade exterior wall than the actual design. BEopt inputs and HERS information can be found in Appendix M and Appendix N.

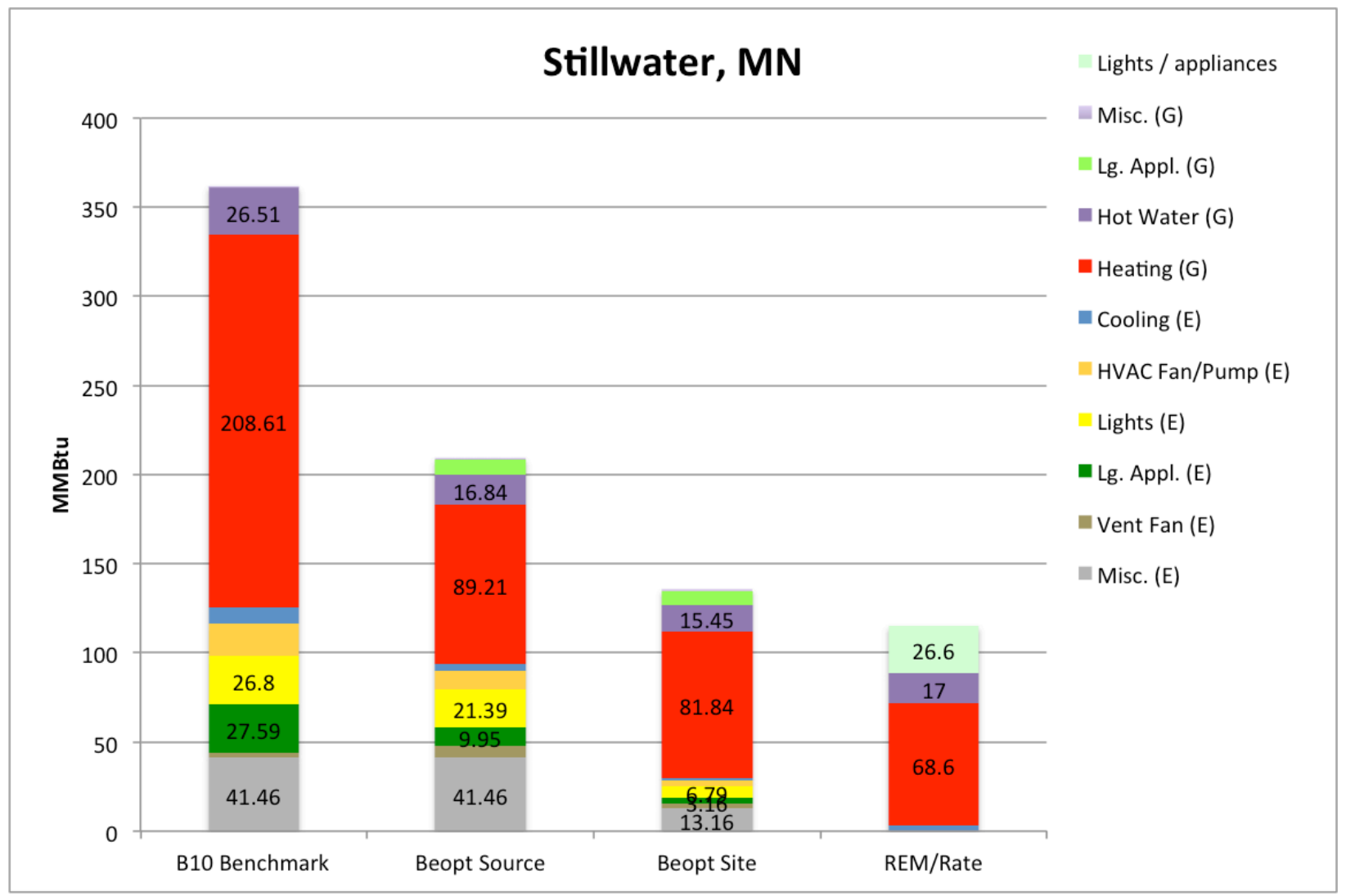

Figure 23. Amaris Custom Homes: Energy modeling results for the Stillwater, Minnesota, project 


\subsection{Cobblestone Homes: Midland, Michigan, Project}

\subsubsection{Basic Project Information}

This 4,008- $\mathrm{ft}^{2}$, 4-bedroom, 31/2-bathroom, 1-story home with finished basement is located in Climate Zone 5. This home was a DOE ZERH 2014 Housing Innovation Award winner. (See Appendix O.)

\subsubsection{Technical Characteristics of Typical Construction Practices and DOE ZERH Solutions}

Table 8. Cobblestone Homes: Midland, Michigan, Project

\begin{tabular}{|c|c|c|}
\hline Measure & Typical Construction Practices & ZERH Solution \\
\hline Infiltration & $3.0 \mathrm{ACH} 50$ & $1.65 \mathrm{ACH} 50$ \\
\hline Cooling Equipment & 13 SEER & 13 SEER \\
\hline Heating Equipment & Natural gas, 96 AFUE & Natural gas, 96 AFUE \\
\hline Water Heater & Natural gas, 0.63 EF & Natural gas, 0.63 EF \\
\hline Lighting & 90\% ENERGY STAR & 90\% ENERGY STAR \\
\hline Thermostat & Programmable & Programmable \\
\hline Dishwasher & ENERGY STAR rated & ENERGY STAR rated \\
\hline Refrigerator & ENERGY STAR rated & ENERGY STAR rated \\
\hline Clothes Washer & ENERGY STAR rated & ENERGY STAR rated \\
\hline Ceiling Insulation & $\mathrm{R}-49$ & $\mathrm{R}-49$ \\
\hline $\begin{array}{c}\text { Above-Grade Wall } \\
\text { Insulation }\end{array}$ & R-20.6 & R-20.6 \\
\hline Foundation Insulation & $\mathrm{R}-10$ & R-11.5, with R-5 under slab \\
\hline Windows & $\begin{array}{c}\text { Double-pane, Low-e windows } \\
\text { with U-0.28 and } 0.28 \text { SHGC }\end{array}$ & $\begin{array}{l}\text { Double-pane, Low-e windows } \\
\text { with U-0.28 and } 0.28 \text { SHGC }\end{array}$ \\
\hline Ventilation & HRV & ERV \\
\hline Duct Systems & $\begin{array}{l}\text { Located within the thermal and } \\
\text { air barrier, sealed }\end{array}$ & $\begin{array}{l}\text { Located within the thermal and } \\
\text { air barrier, fully ducted, sealed }\end{array}$ \\
\hline
\end{tabular}


A unique feature of this home is the $1.4 \mathrm{~kW}$ of PV roof tiles. The PV tiles are made of a flexible material that has the same dimensions and thickness as asphalt shingles. Rather than sit-on-top panels, the tiles are integrated with the shingles as part of the roofing layer. The home's roof structure and orientation on the lot were designed to allow room for up to $891 \mathrm{ft}^{2}$ of PV tiles.

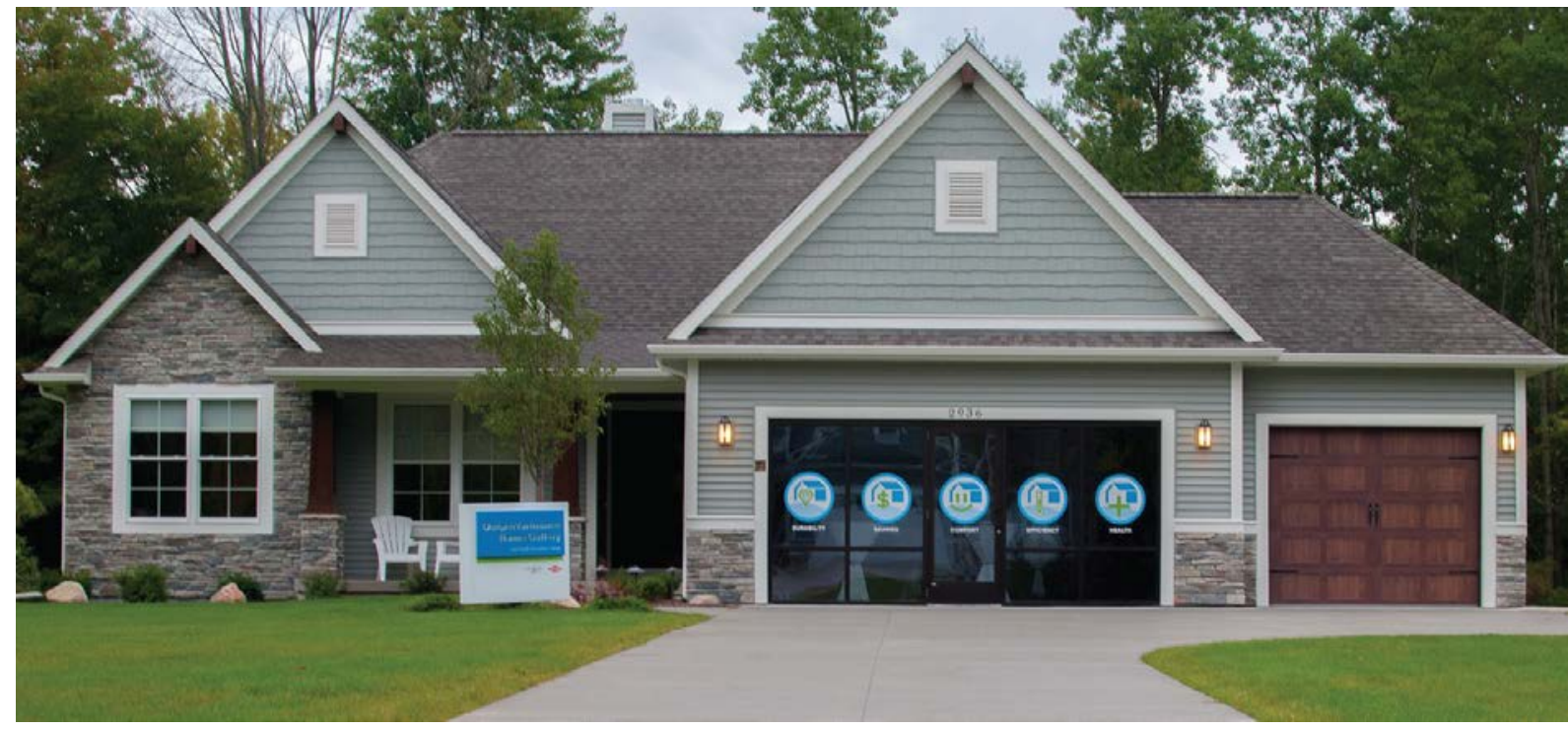

Figure 24. Cobblestone Homes: Front elevation of the Midland, Michigan, project

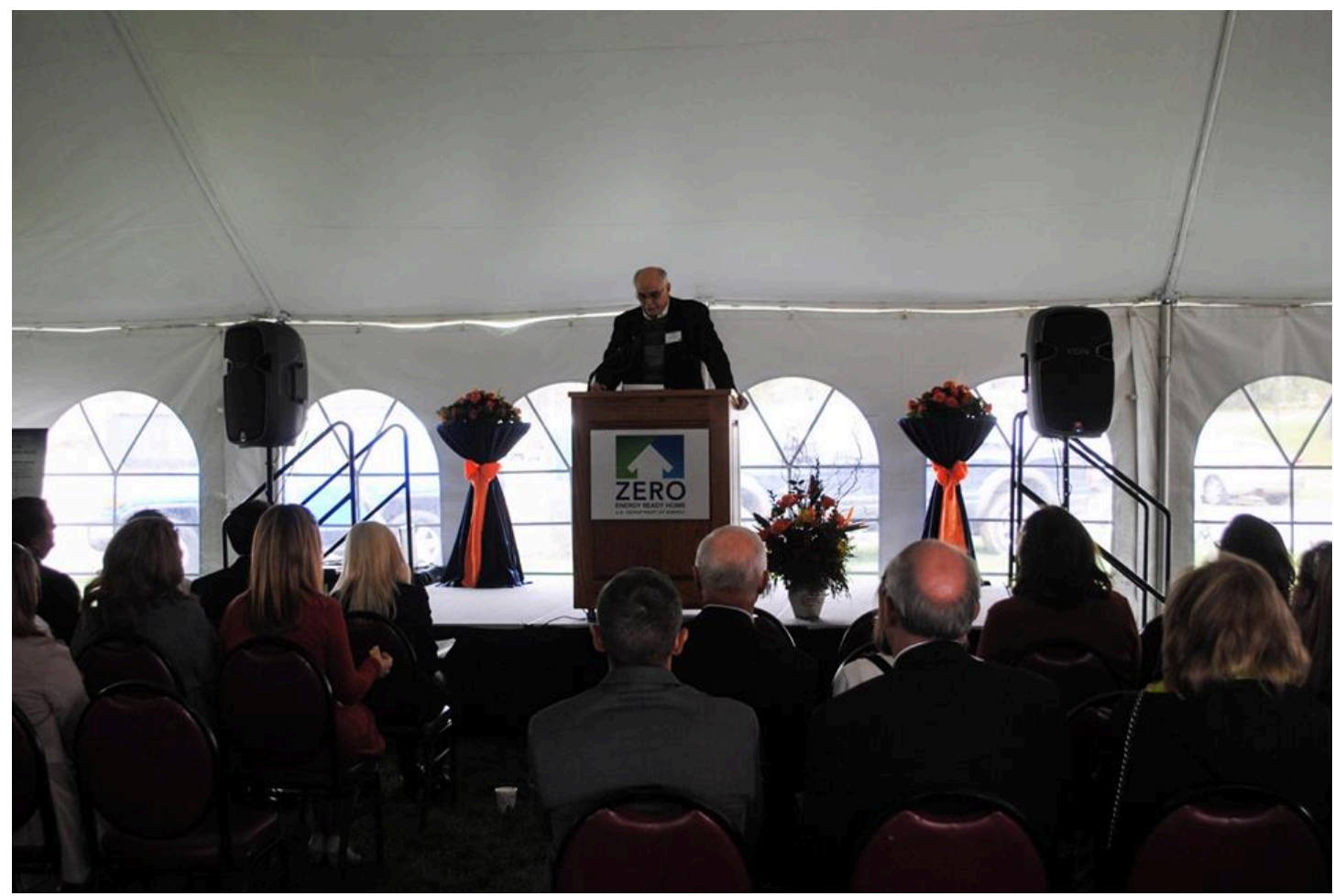

Figure 25. Pat Huelman from the NorthernSTAR Building America team at the Cobblestone Innovation event 


\subsubsection{Energy Modeling}

Figure 26 shows the energy modeling results for Cobblestone Homes' Midland, Michigan, project. Predictions of site energy use were nearly identical between the two models: 104 $\mathrm{MMBtu} / \mathrm{yr}$ for BEopt and $102 \mathrm{MMBtu} / \mathrm{yr}$ REM/Rate. In addition, PV output predictions were identical, at $6 \mathrm{MMBtu} /$ year. BEopt inputs and HERS information can be found in Appendix $\mathrm{O}$ and Appendix P.

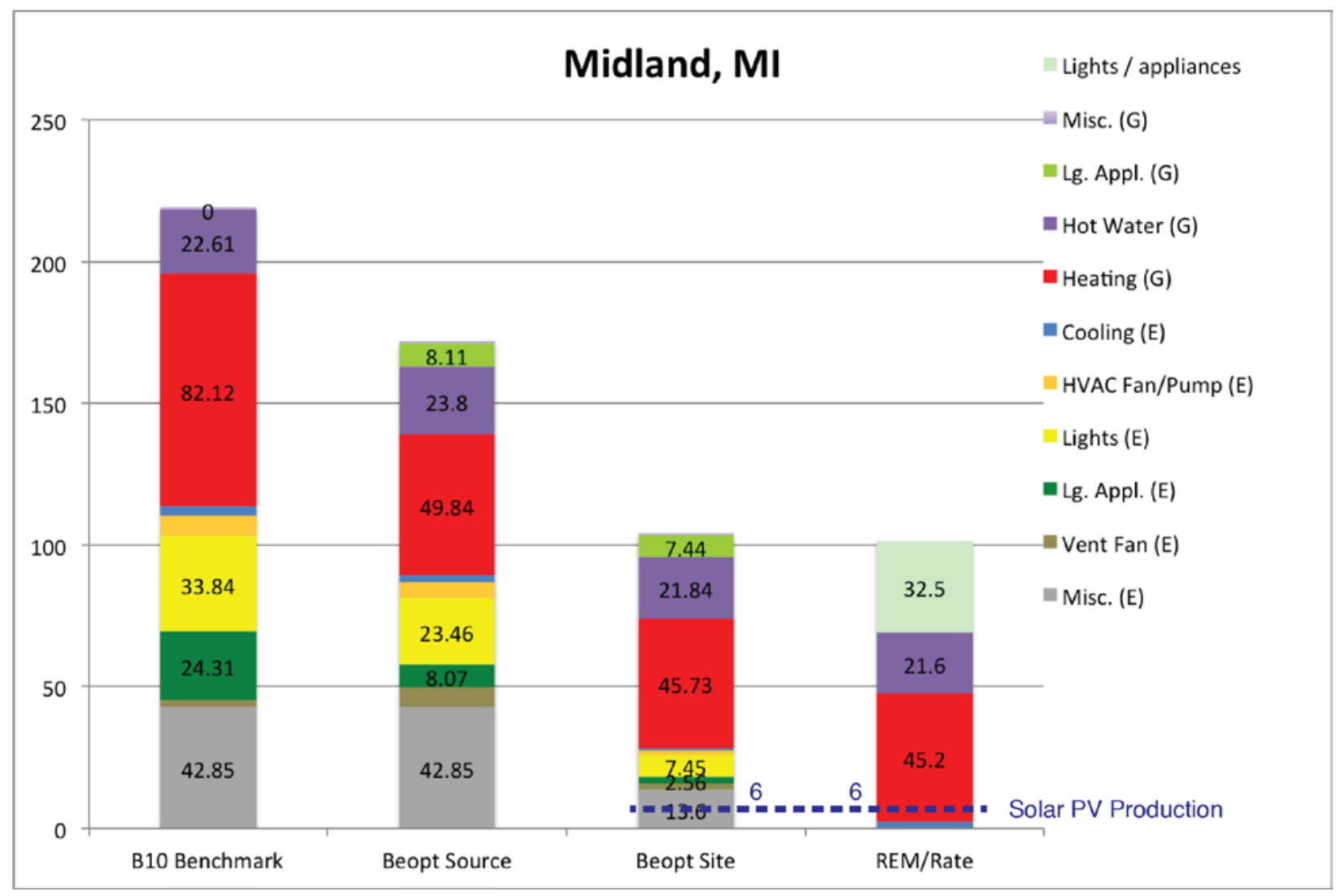

Figure 26. Cobblestone Homes: Energy modeling results for the Midland, Michigan, project 


\subsection{Morrissey Builders: Lake Elmo, Minnesota, Project}

\subsubsection{Basic Project Information}

This 2,930- $\mathrm{ft}^{2}$, 3-bedroom, 21/2-bathroom, 2-story home is currently under construction, and it is located in Climate Zone 6.

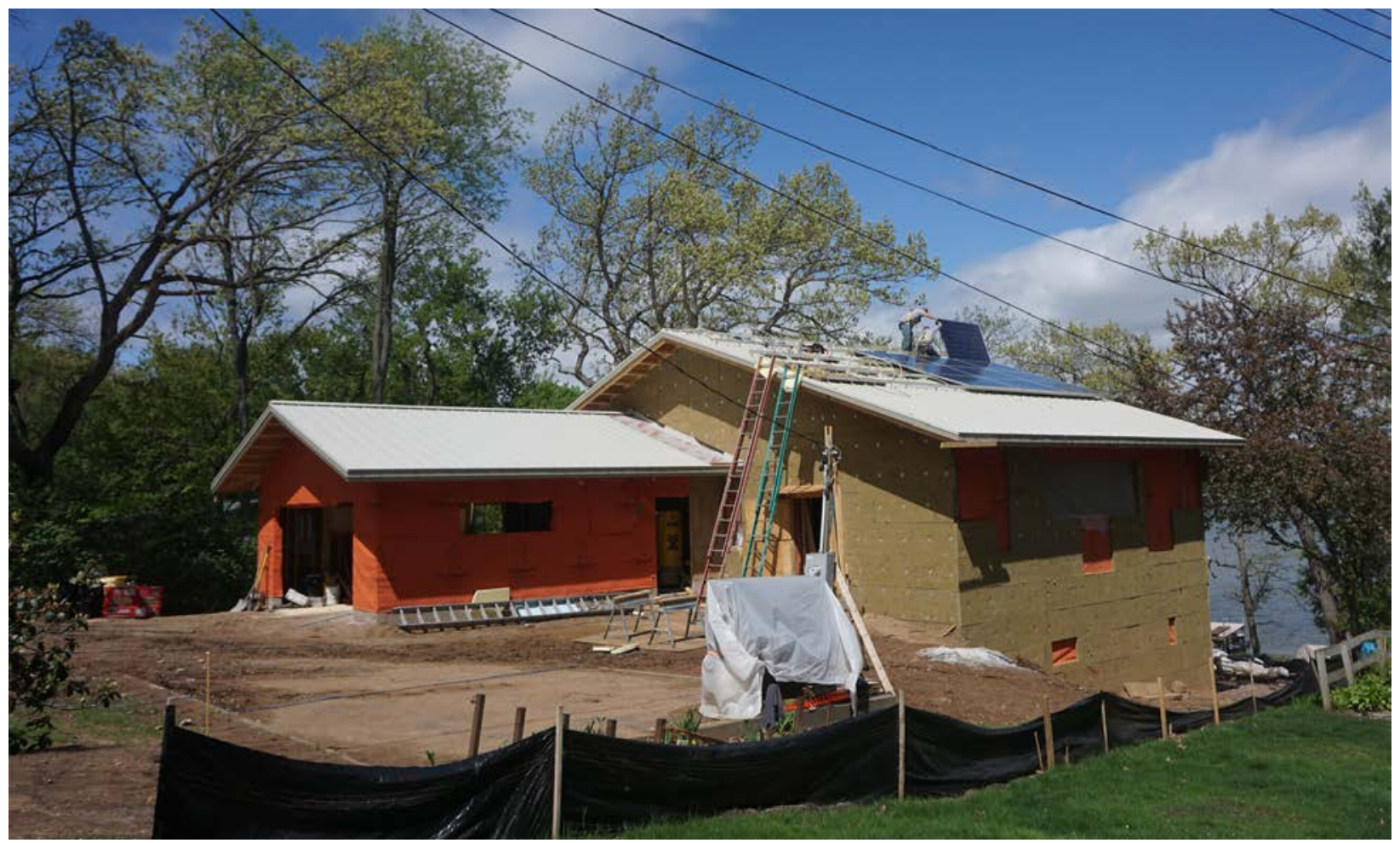

Figure 27. Morrissey Builders: Solar panel installation of the Lake Elmo, Minnesota, project

This client-driven, highly sustainable home is expected to receive the following third-party certifications: Leadership in Energy and Environmental Design for Homes, Minnesota GreenStar, ENERGY STAR, Indoor airPLUS, and ZERH.

The client's vision is for an energy-efficient, locally-sourced, green home wherein the clients can age in place. The goals are to get it as close to net zero energy as possible and to use the house as an educational tool.

The home's preliminary HERS Index is 8 . The preliminary (mid-construction) blower door test result is $0.3 \mathrm{ACH} 50$.

The project team conducted two project tours: one on April 8, 2015, for students of the University of Minnesota and one on June 25, 2015, as an open house various residential building disciplines. The project was also a the topic of a two-hour panel discussion at the American Institute of Architects convention in Minnesota on November 13, 2015. ${ }^{7}$

\footnotetext{
${ }^{7}$ See project website for more information: https://olsonlakehouse.wix.com/brink.
} 


\subsubsection{Technical Characteristics of Typical Construction Practices and DOE} ZERH Solutions

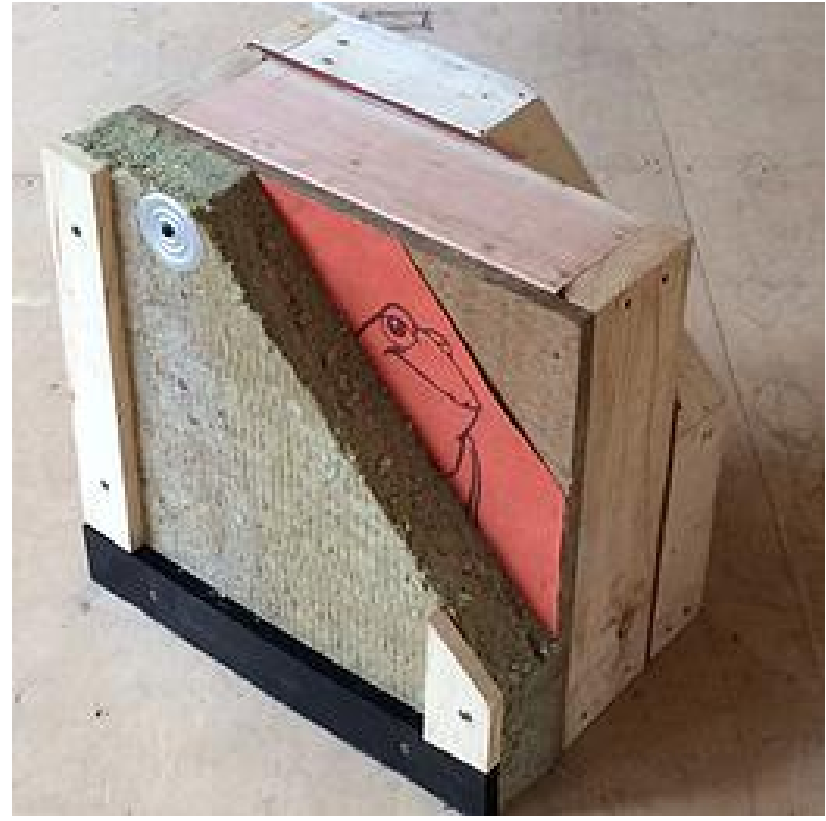

Figure 28. Morrissey Builders: Exterior wall assembly of the Lake Elmo, Minnesota, project

Specifications include wood furring strips for attaching siding, 3 in. of mineral wool insulation, and weather-resistive barrier over $1 / 2$-in. of fiberboard structural sheathing. The $2 \times 6$-in. exterior stud wall (bearing wall) is filled with dense-packed cellulose held in by netting. Half-inch oriented strand board is the interior air barrier. The $2 \times 4$-in. interior stud wall is the chase for wiring, plumbing, and HVAC ductwork. 
Table 9. Morrissey Builders: Lake Elmo, Minnesota, Project

\begin{tabular}{|c|c|c|}
\hline Measure & Typical Construction Practices & ZERH Solution \\
\hline Infiltration & $2.0 \mathrm{ACH} 50$ & $0.3 \mathrm{ACH} 50$ \\
\hline Cooling Equipment & 13.5 SEER & 19.25 SEER \\
\hline Heating Equipment & Natural gas, 95 AFUE & Electric, $10,00 \mathrm{HSPF}^{\mathrm{a}}$ \\
\hline Water Heater & Natural gas, $0.70 \mathrm{EF}$ & Electric, 2.75 EF \\
\hline Lighting & $\mathrm{N} / \mathrm{A}$ & $\begin{array}{c}100 \% \text { ENERGY STAR } \\
\text { CFL/LED }\end{array}$ \\
\hline Thermostat & Programmable & Programmable \\
\hline Dishwasher & ENERGY STAR rated & ENERGY STAR rated \\
\hline Refrigerator & ENERGY STAR rated & ENERGY STAR rated \\
\hline Clothes Washer & ENERGY STAR rated & ENERGY STAR rated \\
\hline Ceiling Insulation & $\mathrm{R}-45$ & $\begin{array}{l}\text { R-81: 4-in. exterior continuous } \\
\text { insulation; 16-in. dense-packed } \\
\text { cellulose }\end{array}$ \\
\hline $\begin{array}{c}\text { Above-Grade Wall } \\
\text { Insulation }\end{array}$ & $\mathrm{R}-25$ & $\begin{array}{l}\text { R-49: } 3 \text {-in. exterior continuous } \\
\text { insulation; double-stud wall with } \\
\text { dense-packed cellulose }\end{array}$ \\
\hline Foundation Insulation & R-22 ICF & $\begin{array}{l}\text { R-41: } 3 \text {-in. exterior continuous } \\
\text { insulation on top of } 113 / 4-\text { in. ICF, } \\
\text { below slab } \mathrm{R}-30\end{array}$ \\
\hline Windows & $\begin{array}{l}\text { Double-pane, low-e windows } \\
\text { with U-0.29 and } 0.29 \text { SHGC }\end{array}$ & $\begin{array}{c}\text { Double-pane, low-e, argon-filled } \\
\text { windows with U- } 0.18 \text { and } \\
\text { selective SHGC based on } \\
\text { orientation }\end{array}$ \\
\hline Ventilation & HRV & ERV \\
\hline Duct Systems & $\begin{array}{l}\text { Located within the thermal and } \\
\text { air barrier, fully ducted, sealed } \\
\text { with mastic }\end{array}$ & $\begin{array}{l}\text { Located within the thermal and } \\
\text { air barrier, fully ducted, sealed } \\
\text { with mastic }\end{array}$ \\
\hline
\end{tabular}

${ }^{\mathrm{a}}$ Heating seasonal performance factor 


\subsubsection{Energy Modeling}

Figure 29 shows the energy modeling results for Morrissey Builders' Lake Elmo, Minnesota, project. Predictions of site energy use differed significantly between the two models: 80 $\mathrm{MMBtu} / \mathrm{yr}$ for BEopt and $58 \mathrm{MMBtu} / \mathrm{yr}$ REM/Rate. Differences in predicted heating energy use appear to be largely responsible for this difference. This house included design features that could not be modeled in BEopt. Most significantly, the design includes a walk-out basement. Therefore, the BEopt model allocated all the glazing on the south and east orientations to a single floor. This resulted in a model with a glaze area of approximately $75 \%$. The design also includes complex ceiling geometries that could not be faithfully represented in the BEopt model. Predictions for PV production were very similar, at $35 \mathrm{MMBtu} / \mathrm{yr}$ and $37 \mathrm{MMBtu} / \mathrm{yr}$ for the BEopt and REM/Rate, respectively. BEopt inputs and HERS information can be found in Appendix Q and Appendix R.

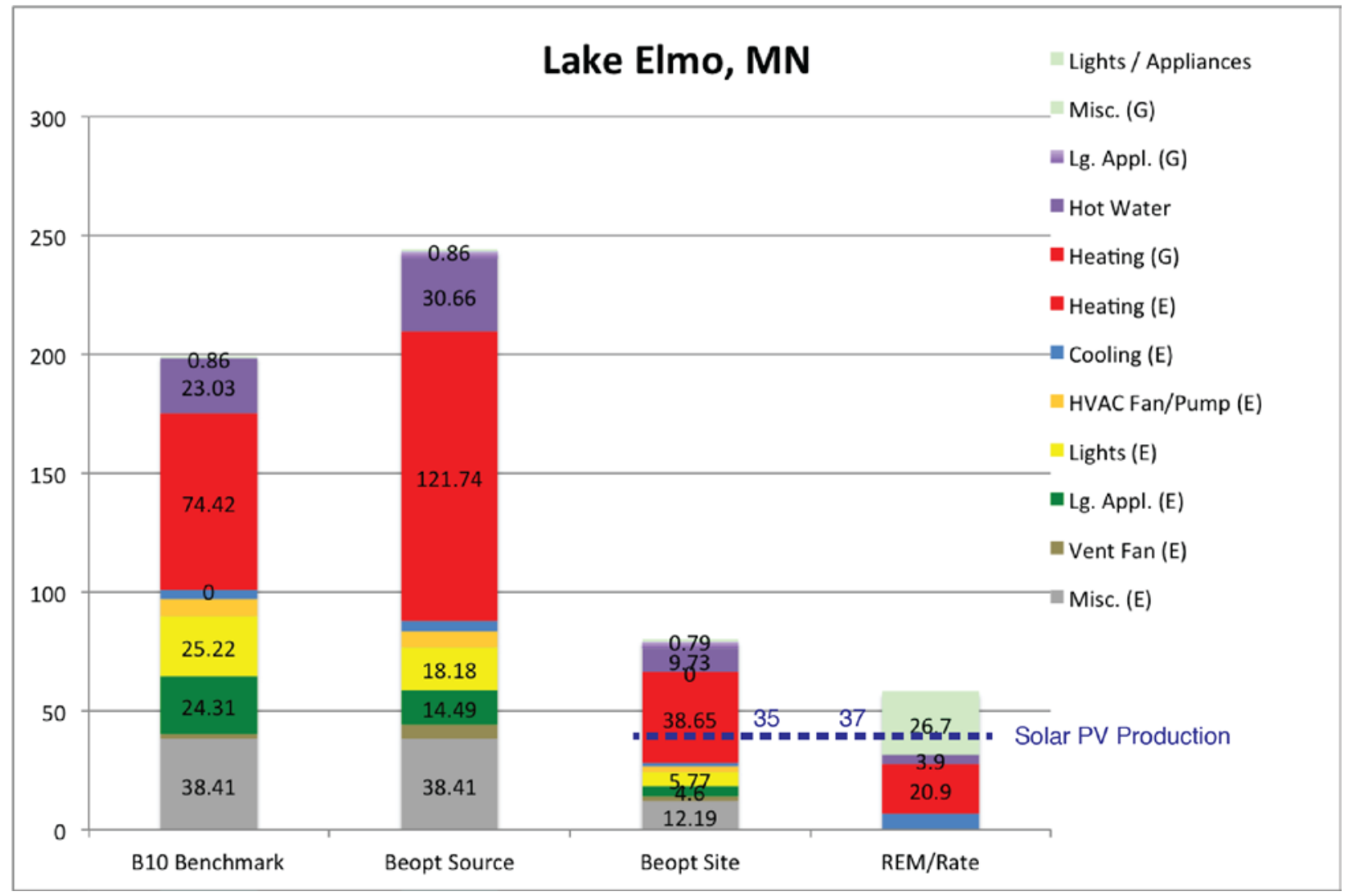

Figure 29. Morrissey Builders: Energy modeling results for the Lake Elmo, Minnesota, project 


\subsection{Urban Homeworks: North Minneapolis, Minnesota, Project}

\subsubsection{Basic Project Information}

This 2,115- $\mathrm{ft}^{2}, 3$-bedroom, 21/2-bathroom, 2-story home with finished basement is currently under construction, and it is located in Climate Zone 6

The target HERS Index for this home is 55. The home's preliminary HERS Index is 41 .

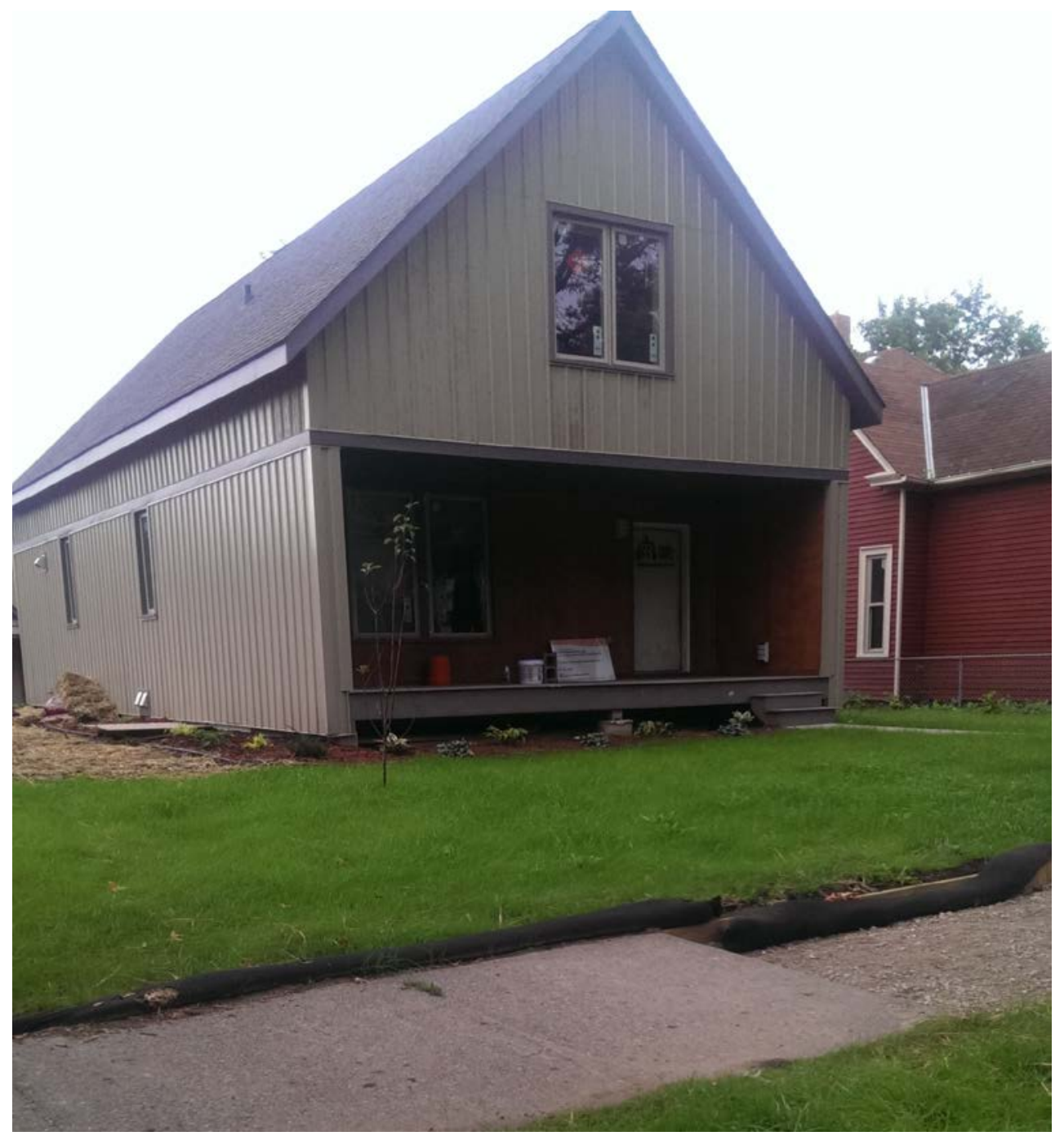

Figure 30. Urban Homeworks: Front elevation of the North Minneapolis, Minnesota, project 


\subsubsection{Technical Characteristics of Typical Construction Practices and DOE ZERH Solutions}

Table 10. Urban Homeworks: North Minneapolis, Minnesota, Project

\begin{tabular}{c|c|c}
\hline Measure & Typical Construction Practices & ZERH Solution \\
\hline Infiltration & 3.0 ACH50 & 2.0 ACH50 \\
\hline $\begin{array}{c}\text { Cooling Equipment } \\
\text { Heating Equipment }\end{array}$ & 13 SEER & 13 SEER \\
\hline Water Heater & Natural gas, 95 AFUE & Natural gas, 96 AFUE \\
\hline Lighting & Natural gas, 0.70 EF & Natural gas, 0.96 EF \\
\hline Thermostat & N/A & $100 \%$ ENERGY STAR \\
CFL/LED
\end{tabular}




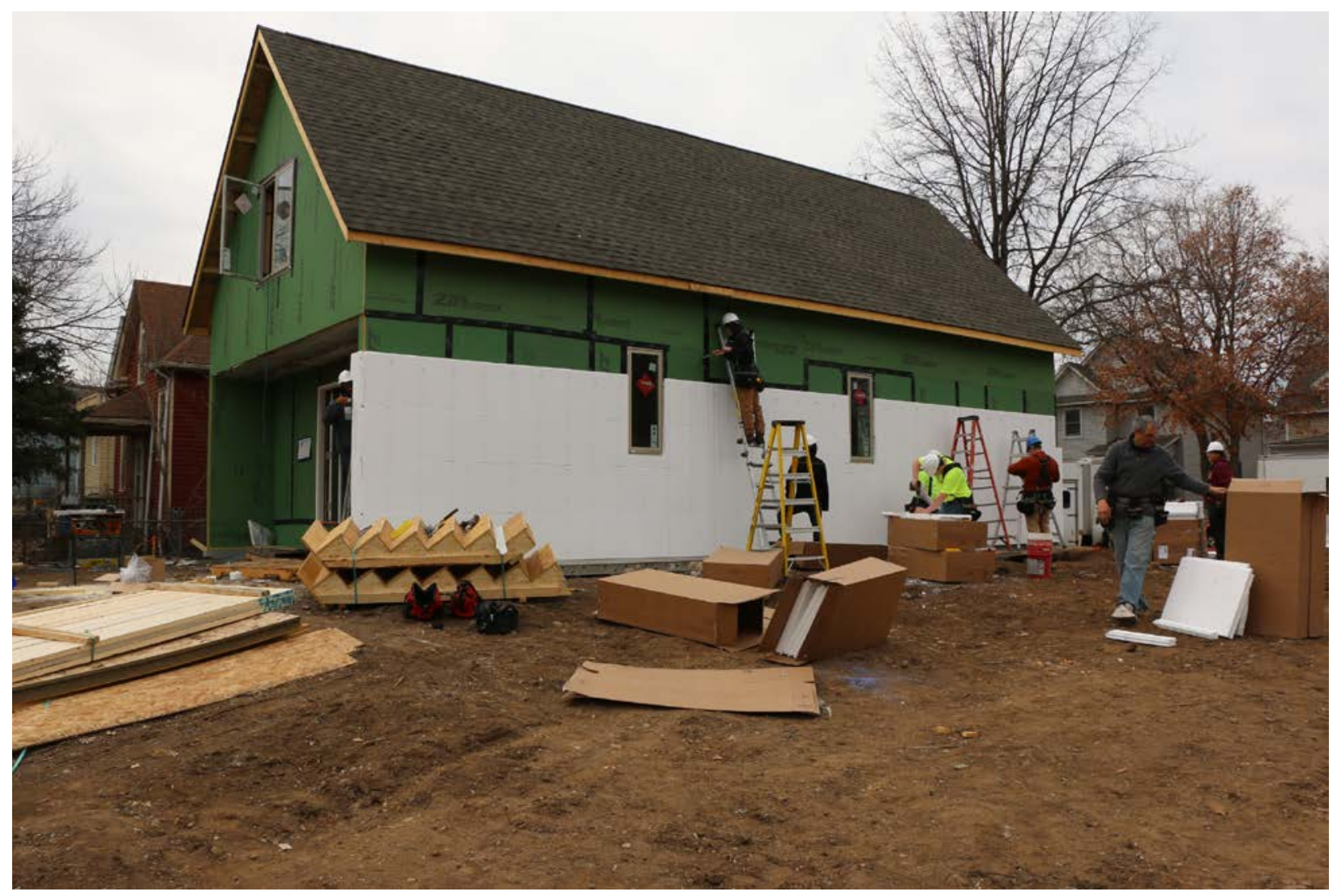

Figure 31. Urban Homeworks: Expanded polystyrene continuous insulation with embedded polypropylene attachment studs of the North Minneapolis, Minnesota, project

This report is available at no cost from the National Renewable Energy Laboratory (NREL) at www.nrel.gov/publications. 


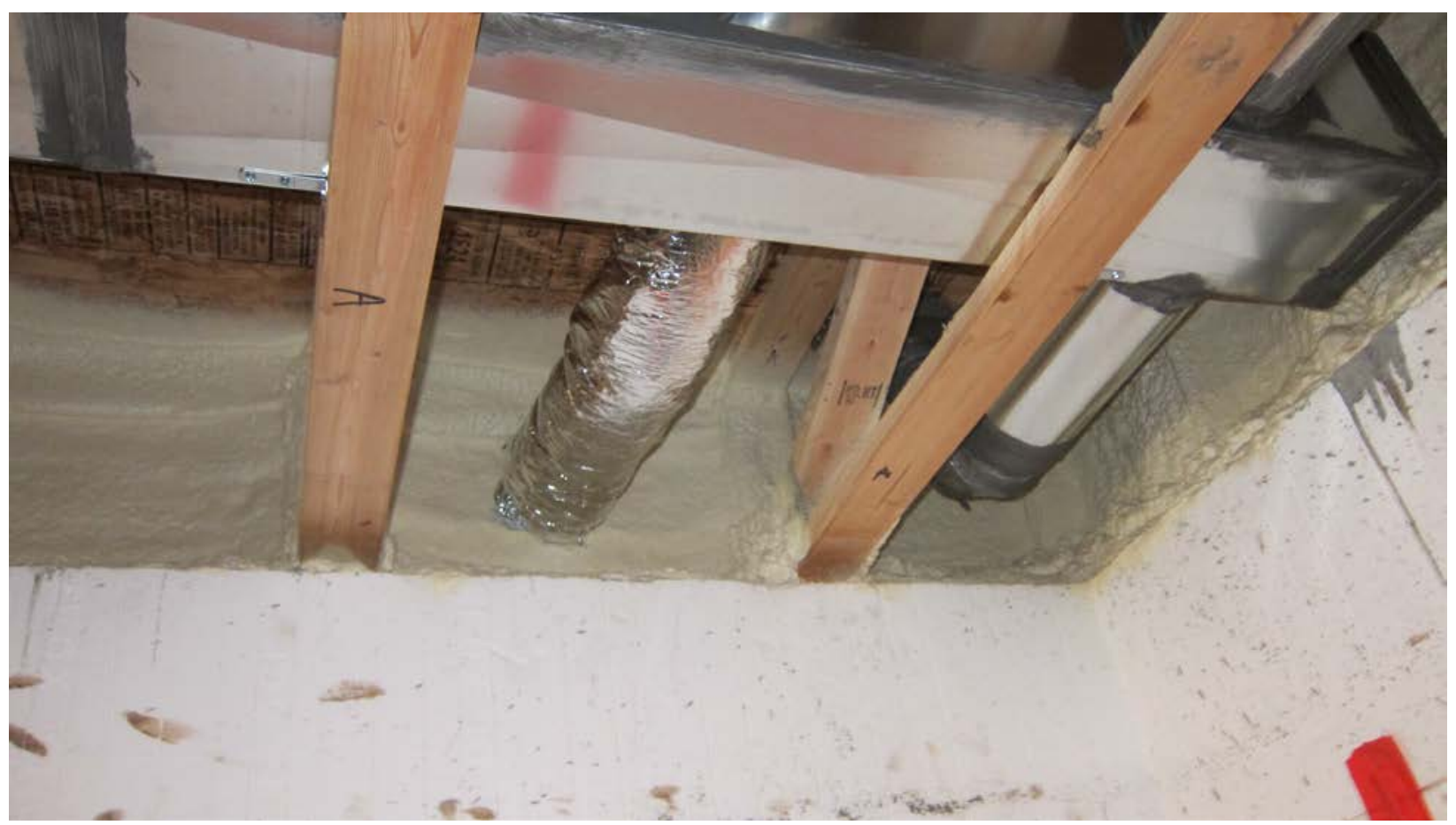

Figure 32. Urban Homeworks: ICF foundation, closed-cell spray foam at rim joist, and sealed ductwork located within the thermal enclosure of the North Minneapolis, Minnesota, project

This report is available at no cost from the National Renewable Energy Laboratory (NREL) at www.nrel.gov/publications. 


\subsubsection{Energy Modeling}

Figure 33 shows the energy modeling results for Urban Homeworks' North Minneapolis, Minnesota, project. Predictions of site energy use differed significantly between the two models: BEopt and REM/Rate. It appears that differences in predicted heating energy use and water heating energy use were largely responsible for this. This house included design features that could not be modeled in BEopt. The design is a simple gable story-and-a-half, with the second floor cantilevering beyond the first floor on the east and west elevations. BEopt cannot model this geometry. The model could have been created as a story-and-a-half with no cantilever or a two-story with a cantilever. The latter option was selected to capture the effect of the interzonal floor that occurs at the cantilever. However, this resulted in significantly more surface area than the actual house and REM/Rate model. BEopt inputs and HERS information can be found in Appendix S and Appendix T.

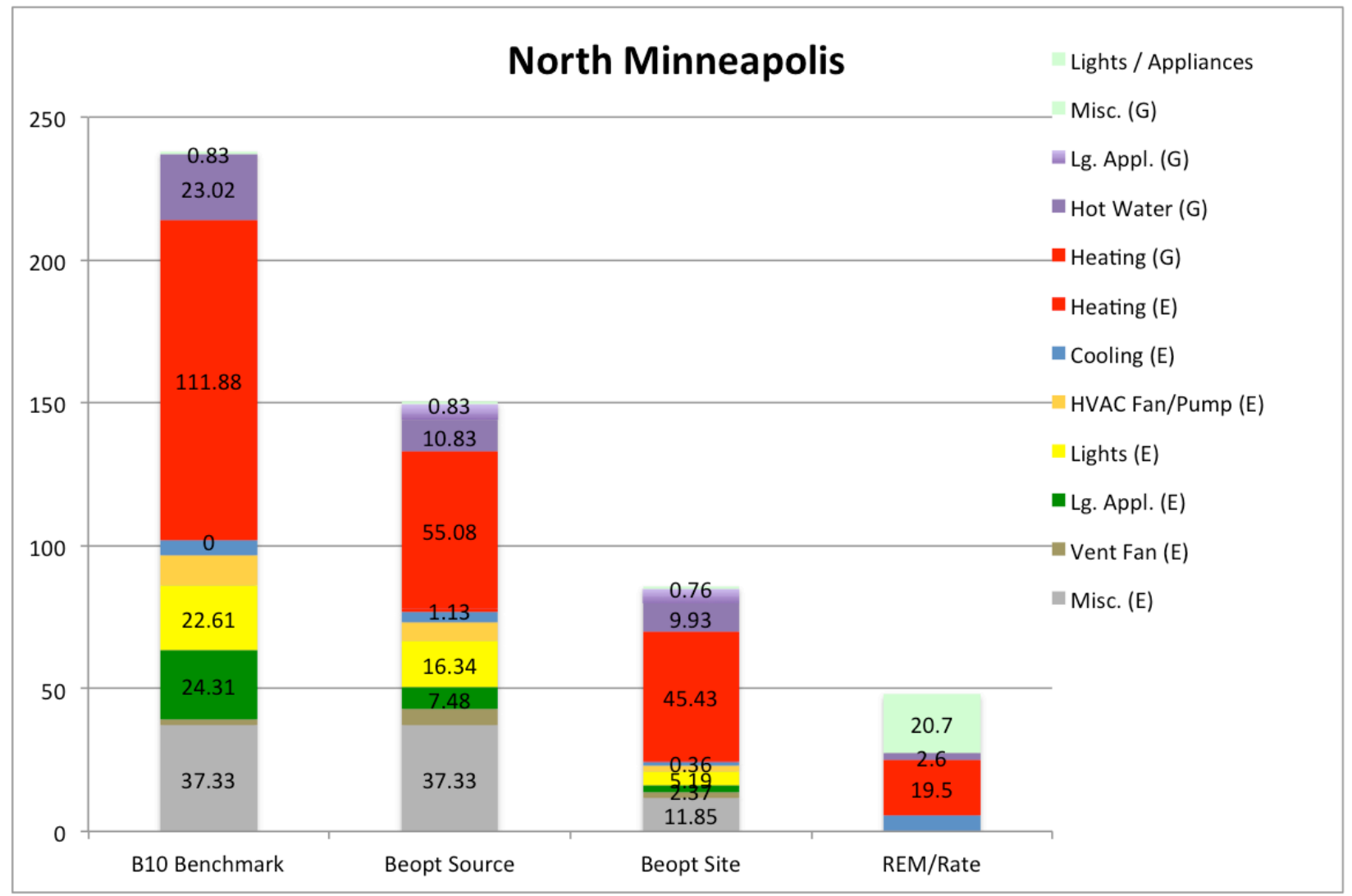

Figure 33. Urban Homeworks: Energy modeling results for the North Minneapolis, Minnesota, project 


\section{Analysis}

\subsection{Barriers}

\subsubsection{HVAC System Quality Installation}

HVAC system quality installation continues to be a challenge for homebuilders in achieving ZERH certification. Currently, there are only 18 credentialed HVAC contractors in the state of Minnesota (compared to 14,000 licensed residential contractors). Many of these contractors obtained their credentials to meet the Enterprise Green Communities ENEGY STAR criteria that are mandatory for state-funded affordable-housing projects. Additionally, our experience demonstrates that even with the credentialing, field crews' lack of experience and training often results in HVAC system designs and installations that do not meet the program requirements. Specific items that require corrective action include Manual J and D calculations and the sealing of ducts, filter compartments, and furnace cabinets.

\subsubsection{Exterior Wall Continuous Insulation 4.1.2.1 Morrissey Builders}

Morrissey Builders chose to install the fiber cement siding to furring strips attached through the mineral wool continuous insulation to the wall framing. The builder encountered detail challenges at structural elements (i.e., deck ledgers) and fenestrations that required unique solutions to minimize thermal bridging and address the extra thickness of the insulation and furring while maintaining the architectural detailing.

\subsubsection{Urban Homeworks}

The exterior siding style chosen by the architect for the Urban Homeworks project required horizontal strapping on top of the expanded polystyrene continuous insulation embedded polypropylene studs. The additional material and labor costs were not anticipated, and future projects would use traditional siding to take advantage of the embedded studs. The builder chose to install the windows directly to the exterior structural sheathing, which required exterior trim extensions that were not noted on the plans. 


\subsection{Market Opportunities}

\subsubsection{Amaris Custom Homes}

As a result of Amaris Custom Homes' experience in participating in the ZERH program and the positive reaction they received from prospective clients, Amaris Custom Homes is planning on offering a guarantee of zero energy bills for their new homes. ${ }^{8}$

Additionally, Amaris Custom Homes offered a guarantee of no net energy bills for the first 10 years for its 2015 Builders Association of the Twin Cities Fall Parade of Homes ZERH model home. ${ }^{9}$

\subsubsection{Cobblestone Homes}

Cobblestone Homes has had previous experience with the DOE Challenge Home program and appreciates the enhanced marketing opportunities available with the DOE ZERH program.

\subsubsection{Morrissey Builders}

Morrissey Builders is enthusiastic about being a catalyst in the Twin Cities, Minnesota, area and in Wisconsin on building toward zero energy homes through retrofits and new construction.

\subsubsection{Urban Homeworks}

The mission of Urban Homeworks includes innovative approaches to building new, green, energy-efficient, sustainable housing on vacant lots that builds area market value, boosts the local housing market, and increases confidence of current owners.

\footnotetext{
${ }^{8}$ See http://www.startribune.com/homebuilder-pruban-s-aim-is-a-house-without-an-energy-bill/309904841/.

${ }^{9}$ See http://www.prweb.com/releases/2015/09/prweb12938548.htm.
} 


\section{Conclusion}

The volunteer builders' homes featured in this report already provide high-performance criteria that meet or exceed the 2012 International Energy Conservation Code requirements as a result of the builders previous involvement in programs such as ENERGY STAR for Homes, Leadership in Energy and Environmental Design for Homes, Enterprise Green Communities, GreenStar, and Passive House Institute US. Participating in the DOE ZERH program provided an additional framework for the volunteer builders to apply the competencies in energy-efficient construction that they have already developed.

Problems encountered by the builders mainly centered on issues with HVAC quality installation and exterior wall continuous insulation. The most obvious barriers faced by the builders is overcoming the learning curve about the ZERH program requirements and conveying those requirements to their staff and trade contractors as well as to the field crews accomplishing the program requirements. This is exemplified by the three homes that met the technical requirements of the ZERH program but could not be qualified for certification under the program because of the HVAC contractor's unfamiliarity with the credentialing process.

The Building America Solution Center proved to be a valuable resource for the builders and designers especially in addressing the strategies for above-grade wall insulation that would maximize performance and minimize risk and cost.

Energy modeling results were generally very closely aligned in cases where house designs could be accurately represented in BEopt. This suggests that the underlying algorithms in both BEopt and REM/Rate support a common understanding of the energy impact of design decisions, building components, and energy-consuming devices and systems. In cases when building geometry was unable to be modeled in BEopt, however, significant divergence in energy use predictions occurred.

Issues regarding building geometry modeling were encountered while using BEopt on several house designs because of their complexity. Building geometry is automatically generated by BEopt based on building footprint and some menu-driven choices such as roof shape (hip/gable), roof pitch, and eave dimension. This feature makes entering the building geometry for most house designs quick and efficient. However, features such as portions of a house plan that don't intersect at right angles, complex mixes of conditioned and unconditioned spaces in attics, walkout basements, and complex roof forms either cannot be modeled or cause the application to report errors. When geometries cannot be modeled, the modeler is forced to devise proxy ways of modeling the condition in question or to conclude that the physical inaccuracy is not likely to significantly affect the modeling results. In this project, one error was generated due to a complex roof form; BEopt development staff offered an alternative geometrical solution in a timely fashion that enabled the model to run without errors. For most house designs, the geometry generation performed by BEopt is likely to be adequate. However, in the future, overrides may have to be enabled or other alternate methods developed to allow for more faithful modeling of conditions such as those listed above. 
Most of the homes presented in this study have also received enhanced public interest through media events, feature newspaper articles, site tours, and social media posts that demonstrates an increasing acceptance by the public of the benefits of energy-efficient homes.

It is clear that builders can achieve the ZERH certification and will see the performance results in their new homes. We covered the many reasons why more builders should pursue this type of building. However, we also observed some potential barriers that could be addressed in future projects. These barriers include:

- There is a strong resistance to change the building envelope. It seems radical and risky to build a high-performance wall that is too different from traditional $2 \times 6$-in. stud framing.

- Placing insulation on the outside of exterior wall assemblies presents challenges for attaching structural deck ledgers while maintaining a thermal break as well as integration issues with fenestrations and siding attachment.

- Qualified HVAC contractors able to meet the ENERGY STAR criteria are not common in the Minnesota and Michigan markets.

- Some builders tell us they are burned out on "programs." It takes energy and time to redesign and retool to meet the varying requirements. They also question whether the outcome is enough to be a real selling point.

When marketing ZERH, there needs to be enhanced messaging to assist builders in conveying the benefits of ZERH homes to the homebuyers, realtors, appraisers, and press. 


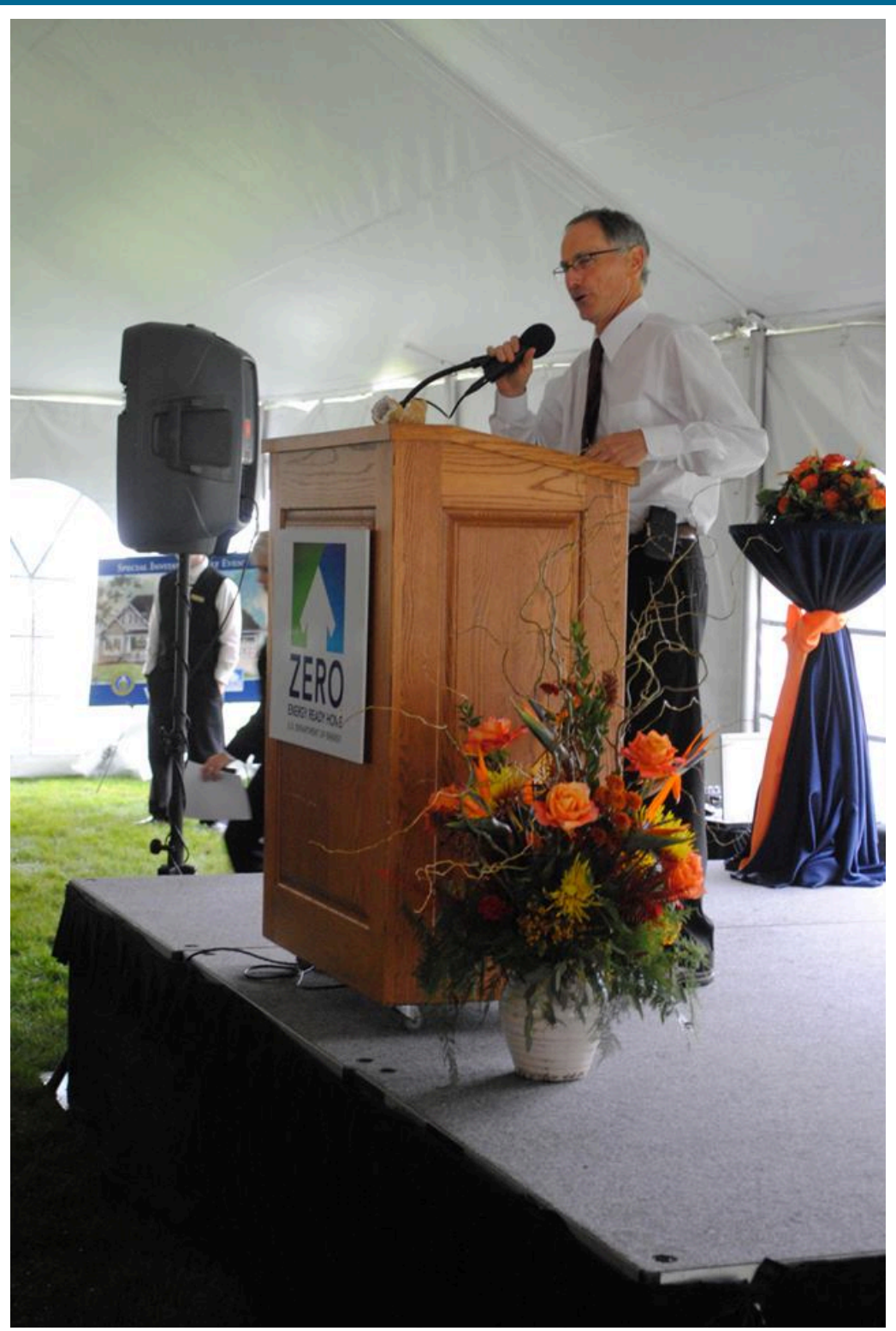

Figure 34. Sam Rashkin, chief architect of DOE, at the Cobblestone Homes DOE Innovation event 


\section{References}

VonThoma, E., and C. Ojczyk. 2012. Practices and Processes of Leading High Performance Home Builders in the Upper Midwest. Golden, CO: National Renewable Energy Laboratory. 


\section{Appendix A: Amaris Custom Homes-St. Paul, Minnesota, Project HERS Reports and Challenge Home Certification}

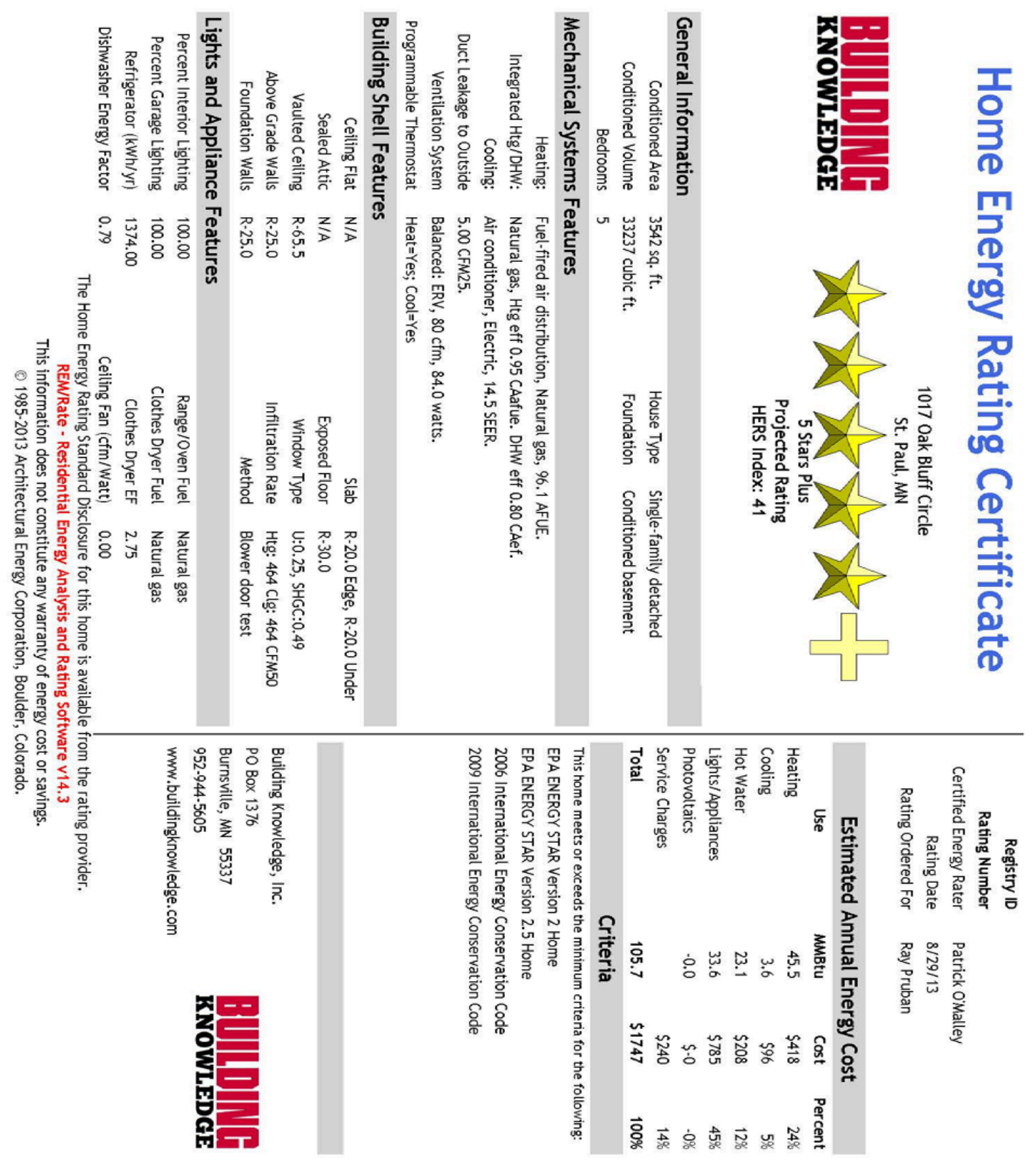




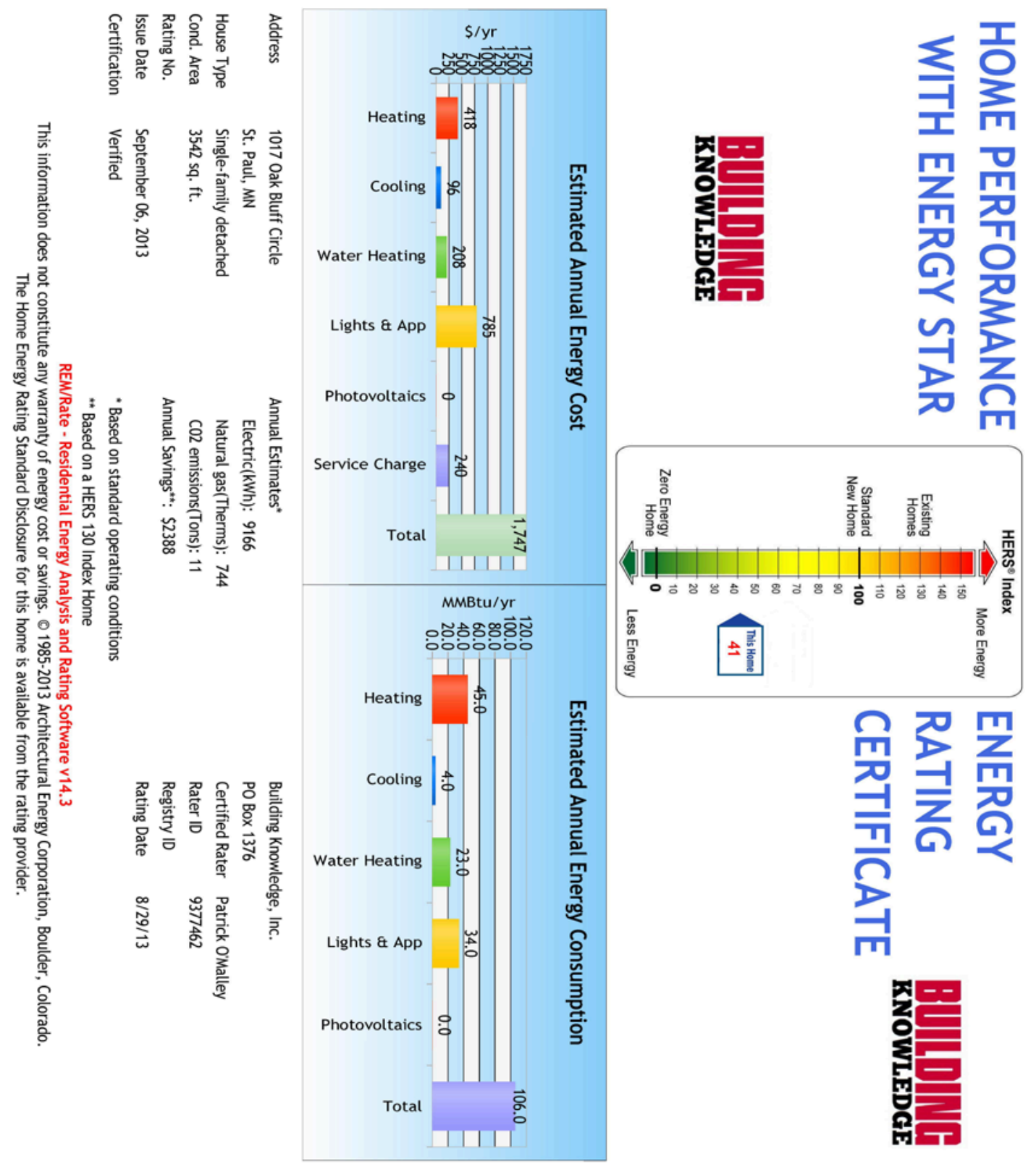




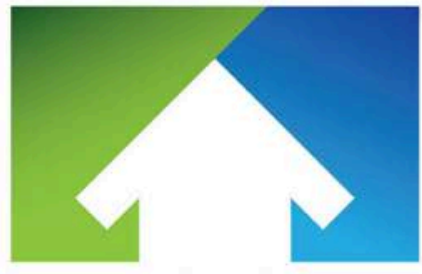

U.S. DEPARTMENT OF ENERGY CHALLENGE HOME

This home built at By Verified by

\section{Amaris Homes, LLC}

Patrick O'Malley

an independent professional organization, to meet or exceed strict home performance guidelines set by

The U.S. Department of Energy on $10 / 24 / 2013$

THIS HOME MEETS OR EXCEEDS THE MINIMUM CRITERIA FOR THE FOLLOWING:

YOUR HOME WAS DESIGNED, ENGINEERED, AND CONSTRUCTED IN CONFORMANCE TO U.S. DEPARTMENT OF ENERGY (DOE) GUIDELINES FOR EXTRAORDINARY LEVELS OF EXCELLENCE AND QUALITY.

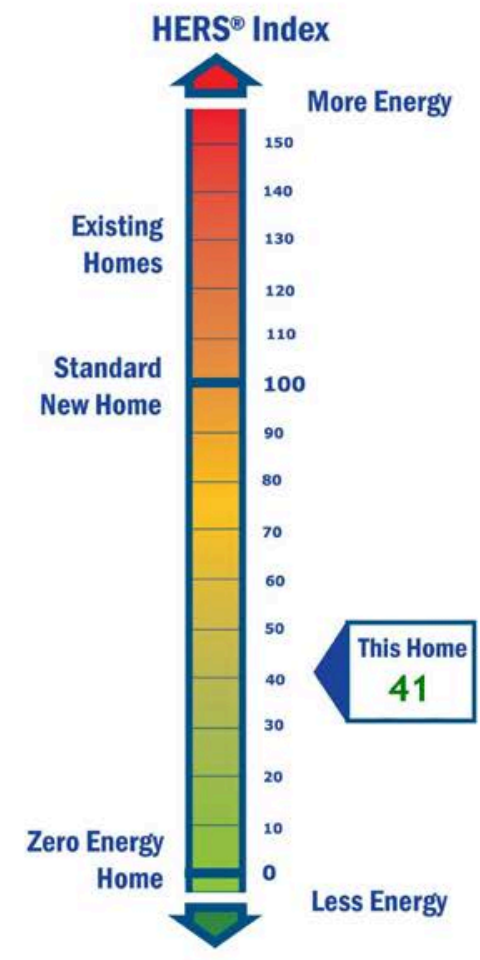

REM/Rate - Residential Energy Analysis and Rating Software v14.3
SAM RASHKIN, CHIEF ARCHITECT BUILDING TECHNOLOGIES

U.S. DEPARTMENT OF ENERGY 


\section{DOE Challenge Home Verification}

\begin{tabular}{|l|l|}
\hline Energy Performance & DOE Challenge Home Builder Partner ID\# \\
\hline House Type & 505 \\
\hline Single-family detached & Square footage of Conditioned Space including Basement \\
\hline Year built & 3542.0 \\
\hline 2013 & Square footage of Conditioned Space without Basement \\
\hline Number of Bedrooms & 3542.0 \\
\hline 4 & Registered Builder \\
\hline Site address (if not available, list the site Lot \#) & Amaris Homes, LLC \\
\hline 1017 Oak Bluff Circle & Certified Rater \\
\hline St. Paul & Patrick O'Malley \\
\hline MN, & Date of Rating \\
\hline HERS Index without On-site Generation & $9 / 13 / 13$ \\
\hline 41 & Rating Software \\
\hline HERS Index with On-site Generation & REM/Rate - v14.3 \\
\hline 41 & Estimated annual energy costs(\$) \\
\hline HERS Index of the Target Home using size adjustment factor & 1713 \\
\hline 49 & Estimated annual energy savings \\
\hline Estimated annual energy use & Electric: 3146 kWh \ Natural gas: 1332 Therms \\
\hline Electric: $8979 \mathrm{kWh} \mathrm{\} \mathrm{Natural} \mathrm{Gas:} 726$ Therms & Estimated annual emissions reductions \\
\hline Energy cost rates & CO2: 10.2 tons / SO2: 6.7 lbs / NOX: 25.3 lbs \\
\hline Electric: 0.09 \$ kWh \ Natural Gas: 0.90 \$/Therms & \\
\hline
\end{tabular}

\section{DOE Challenge Home Certification}

As the certified Rater for this house, I certify this house meets/complies with all mandatory requirments of the DOE Challenge home guidelines, including the following:

\begin{tabular}{|c|l|}
\hline$X$ & Compliance with all ENERGY STAR Qualified Homes Version 3 requirements and checklists \\
\hline X & Compliance with Mandatory Fenestration Requirements \\
\hline X & Compliance with Mandatory Insulation Requirements \\
\hline X & Compliance with Mandatory Duct Location Requirements \\
\hline X & Compliance with Mandatory Appliance Requirements \\
\hline X & Compliance with Mandatory Lighting Requirements \\
\hline X & Compliance with Mandatory Fan Efficiency Requirements \\
\hline X & Compliance with Mandatory Indoor Air Quality Requirements \\
\hline X & Compliance with Mandatory Renewable Energy Ready Solar Electric Requirements \\
\hline X & Compliance with Mandatory Renewable Energy Ready Solar Hot Water Requirements \\
\hline & $\begin{array}{l}\text { This home was qualified via sampling in lieu of testing, in accordance with allowable sampling provisions as stated in the } \\
\text { DOE Challenge Home National Program Requirements }\end{array}$ \\
\hline
\end{tabular}

\section{Optional Compliance for Builder Recognition}

I further certify that the following also apply to this house:

\section{\begin{tabular}{l|l|l|l|l} 
YES & NO & DONT & Optional Home Builder Commitments for Recognition
\end{tabular} \\ KNOW}

*Certification under the DOE Challenge Home permits limited exceptions to full compliance with Indoor airPLUS. Builders seeking the Indoor airPLUS label must achieve full compliance with the Indoor airPLUS Verification Checklist. 


\section{DOE Challenge Home Verification}

Optional Compliance for Builder Recognition
I further certify that the following also apply to this house:
\begin{tabular}{|c|c|c|l|l|}
\hline YES & NO & $\begin{array}{l}\text { DONT } \\
\text { KNOW }\end{array}$ & Optional Home Builder Commitments for Recognition \\
\hline & $X$ & & Certified under the EPA Indoor airPLUS Program \\
\hline & $X$ & & Certified under the EPA WaterSense for New Homes Program \\
\hline & $X$ & & Certified under the IBHS Fortified for Safer Living Program \\
\hline & $X$ & & Followed the DOE Challenge Home Quality Management Guidelines \\
\hline$X$ & & & The buyer of this home signed a waiver giving DOE Challenge Home access to utility bill data for one year \\
\hline
\end{tabular}

*Certification under the DOE Challenge Home permits limited exceptions to full compliance with Indoor airPLUS. Builders seeking the Indoor airPLUS label must achieve full compliance with the Indoor airPLUS Verification Checklist. 


\section{Appendix B: Amaris Custom Homes-St. Paul, Minnesota, Project BEopt Input}

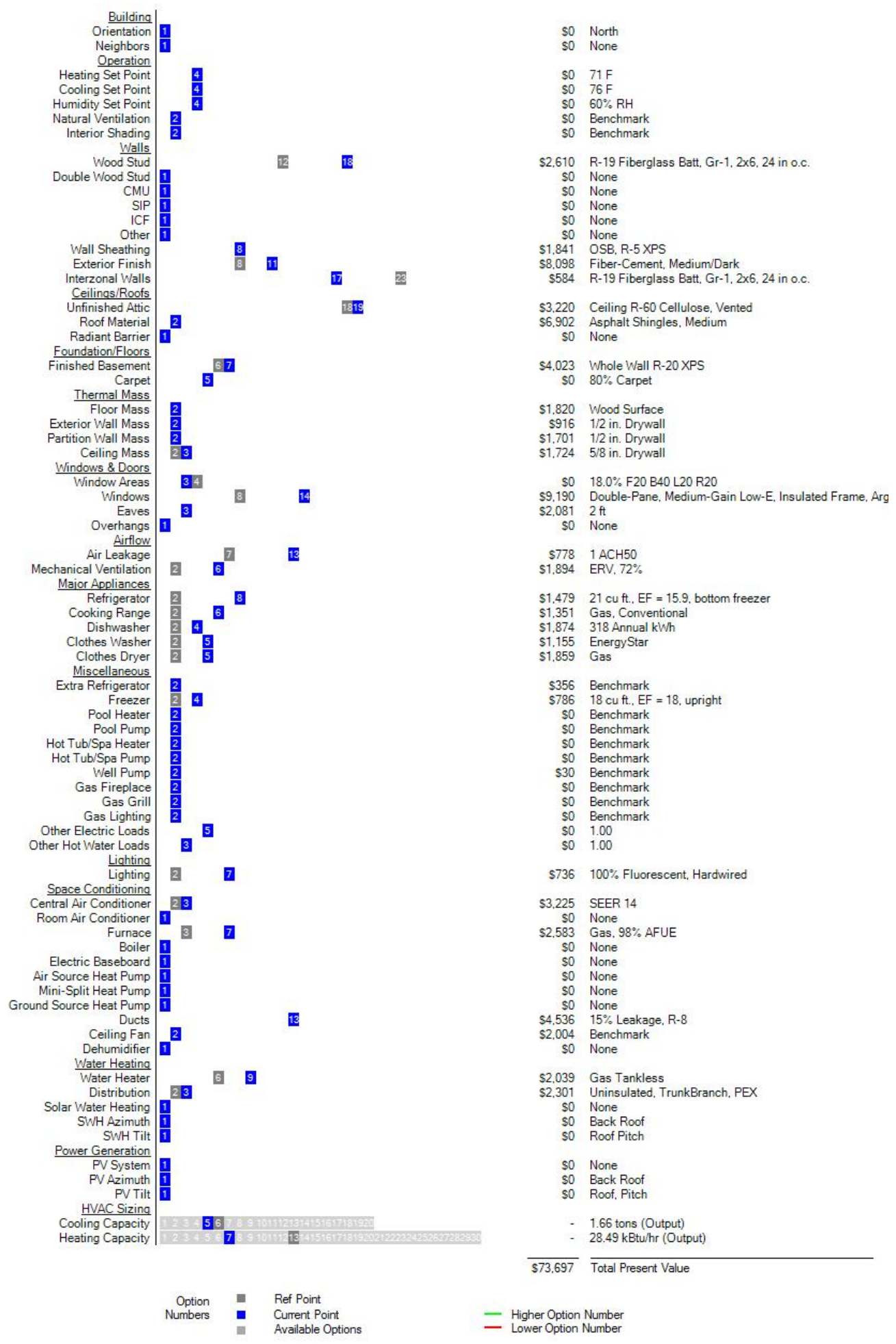




\section{Appendix C: Amaris Custom Homes-Bloomington, Minnesota, Project HERS Reports}

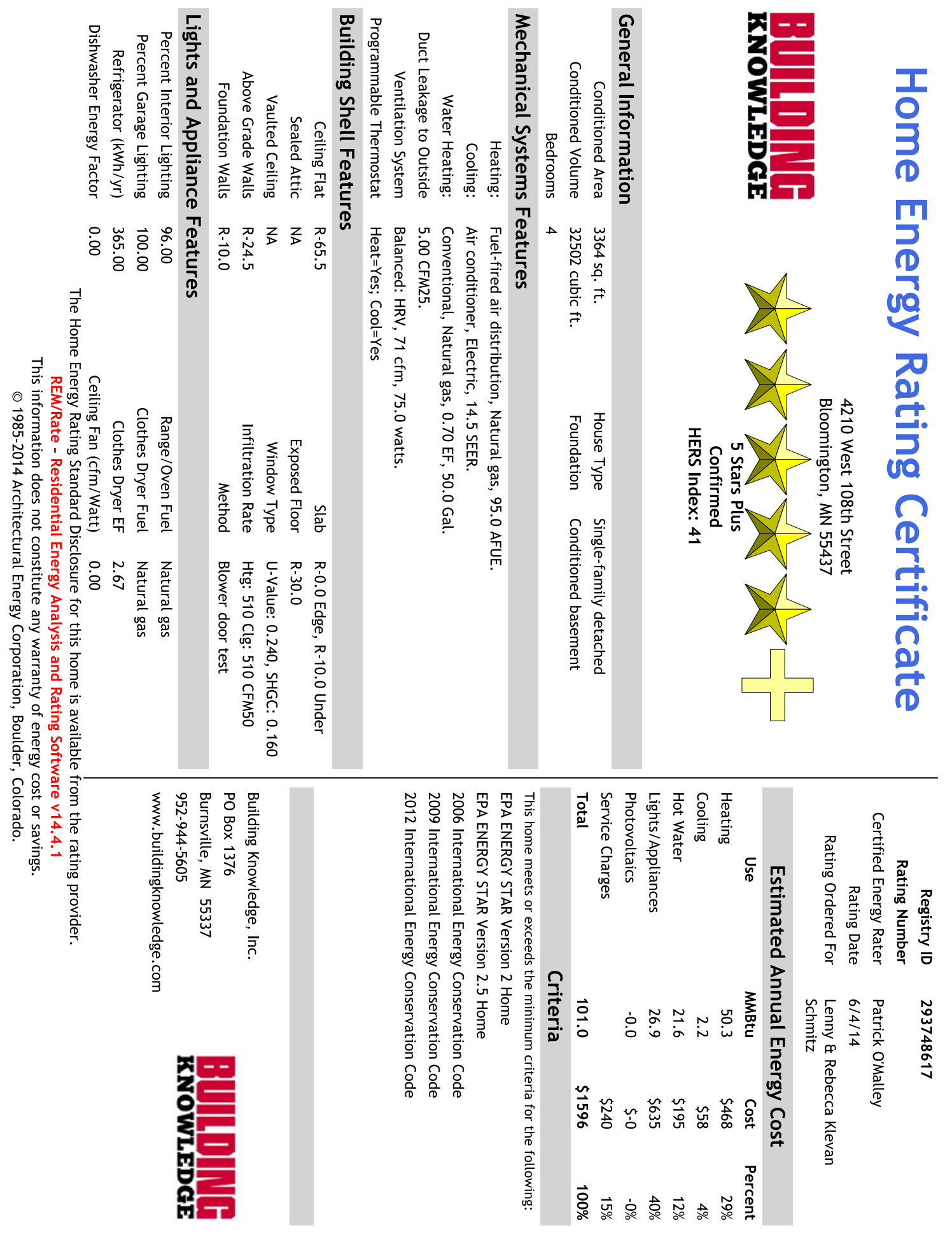




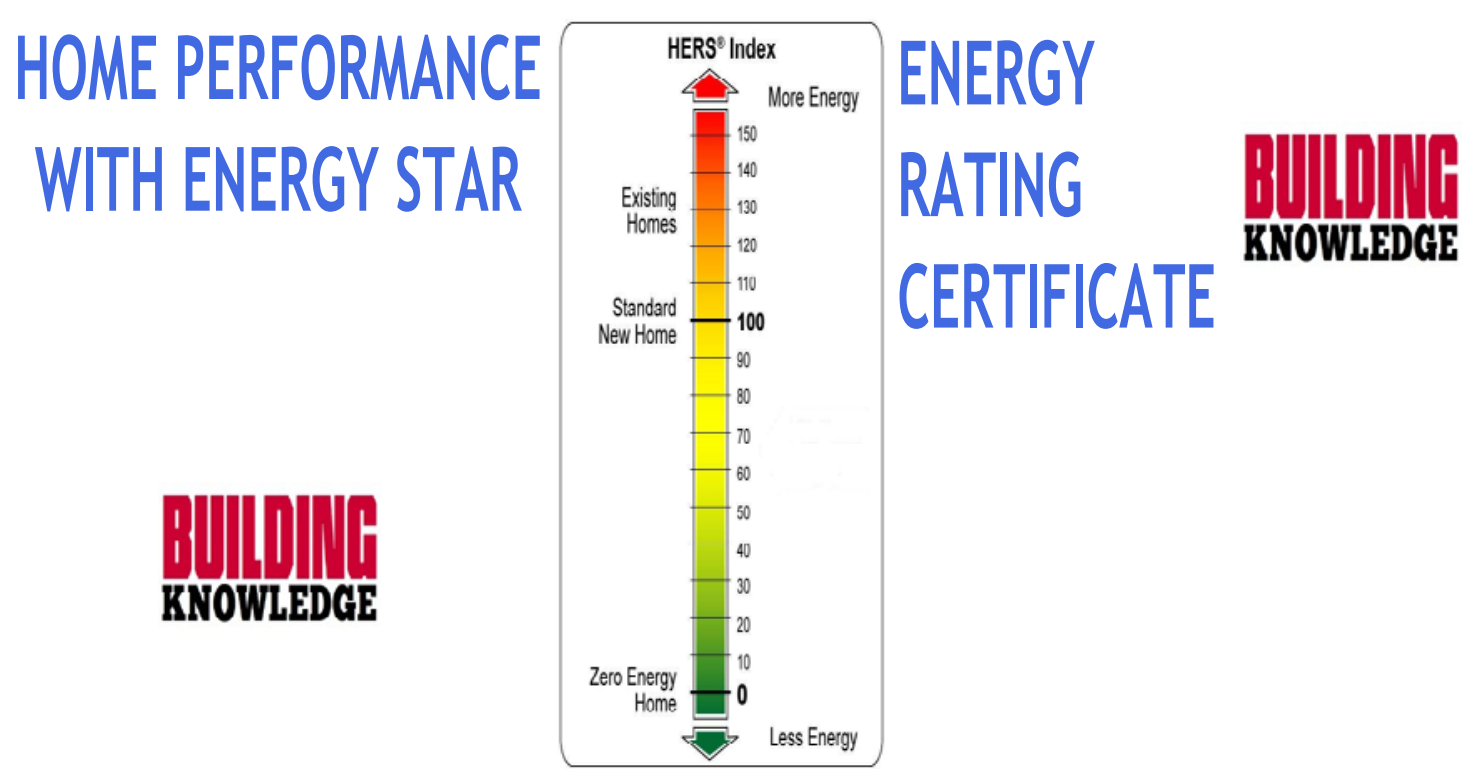

8617

Rating Date $\quad 6 / 4 / 14$

REM/Rate - Residential Energy Analysis and Rating Software v14.4.1

This information does not constitute any warranty of energy cost or savings. ( 1985-2014 Architectural Energy Corporation, Boulder, Colorado.

The Home Energy Rating Standard Disclosure for this home is available from the rating provider. 


\section{Appendix D: Amaris Custom Homes-Bloomington, Minnesota, Project BEopt Inputs}

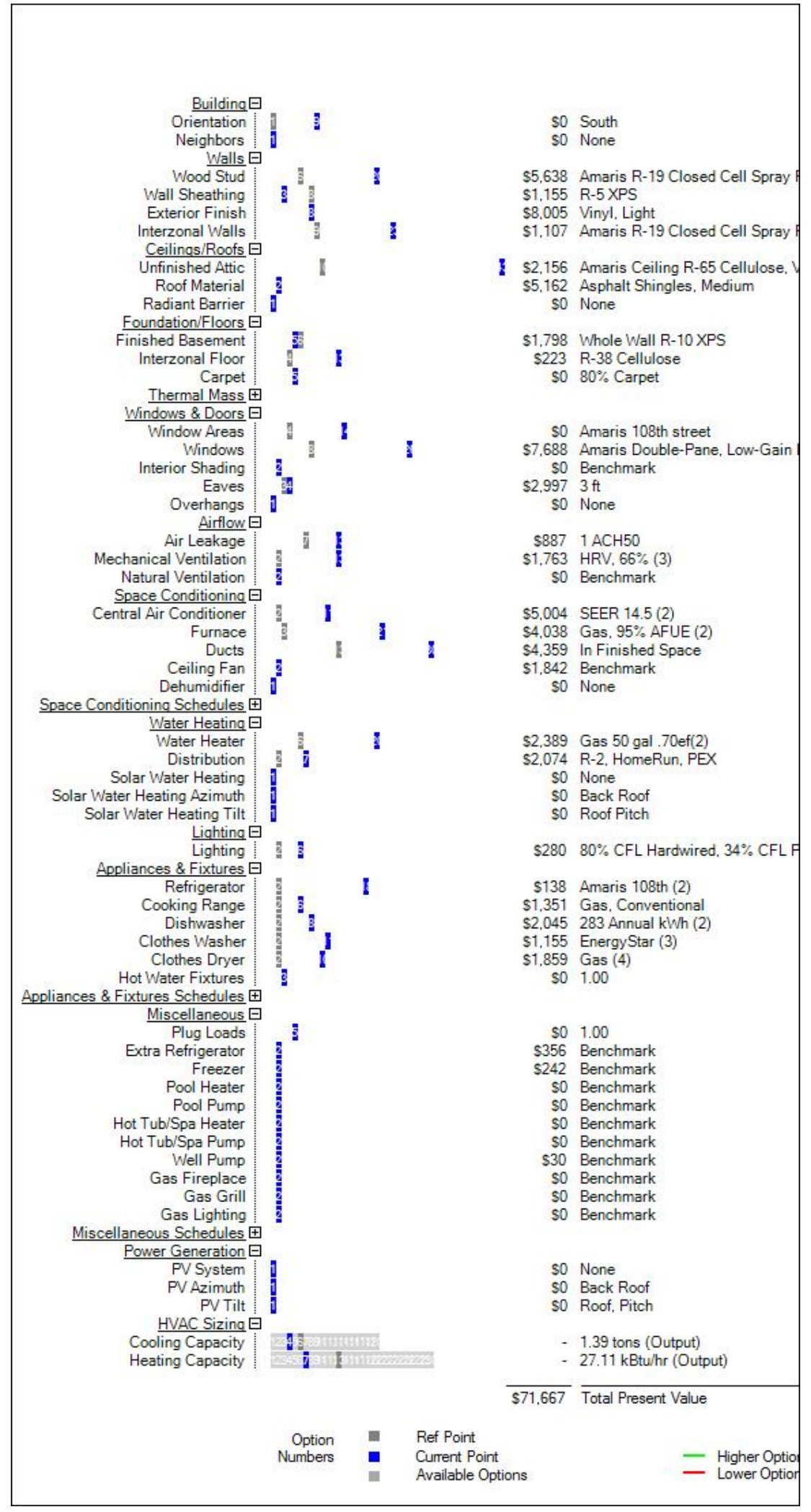




\section{Appendix E: Amaris Custom Homes-Vadnais Heights, Minnesota, Project HERS Reports and ZERH Certification}

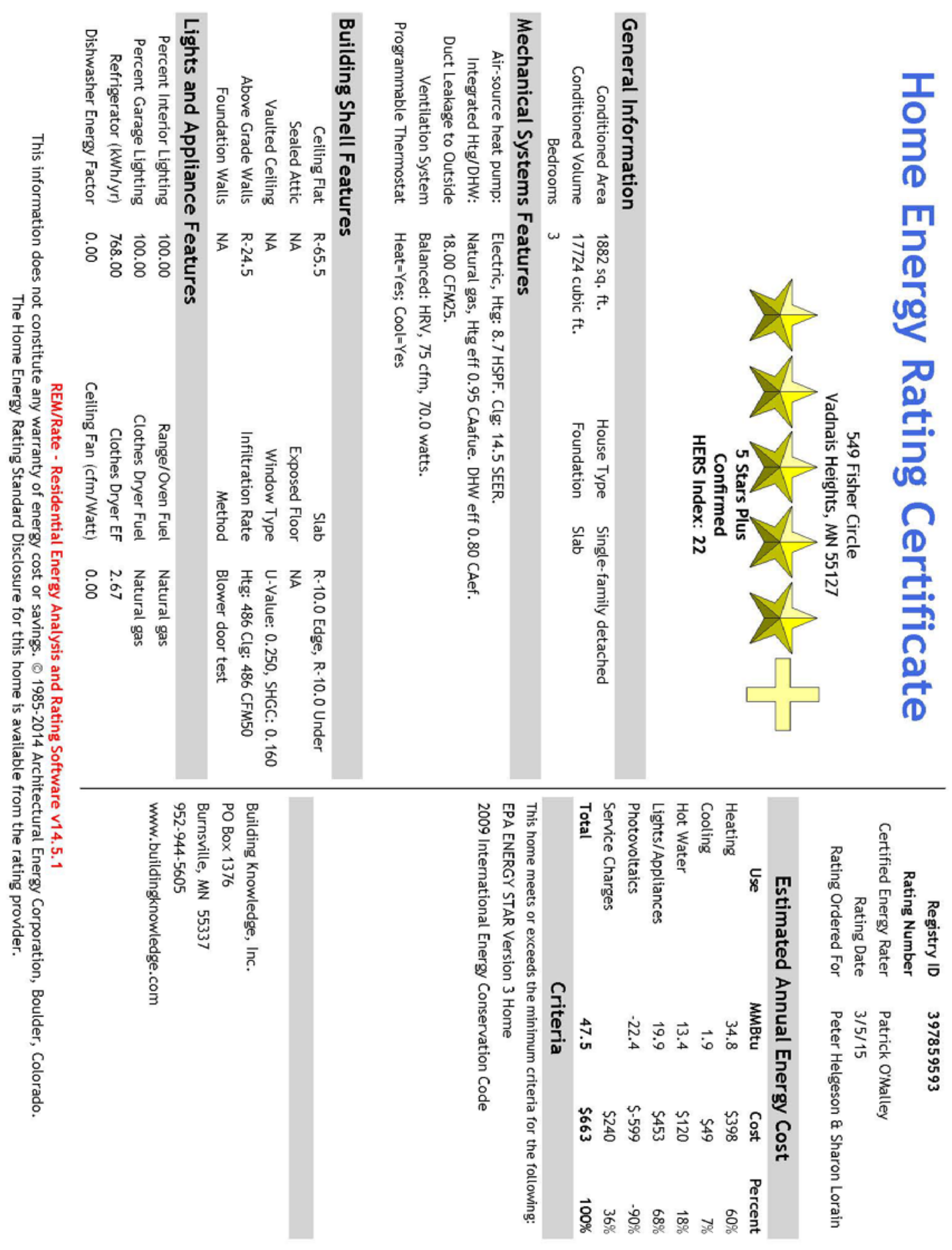




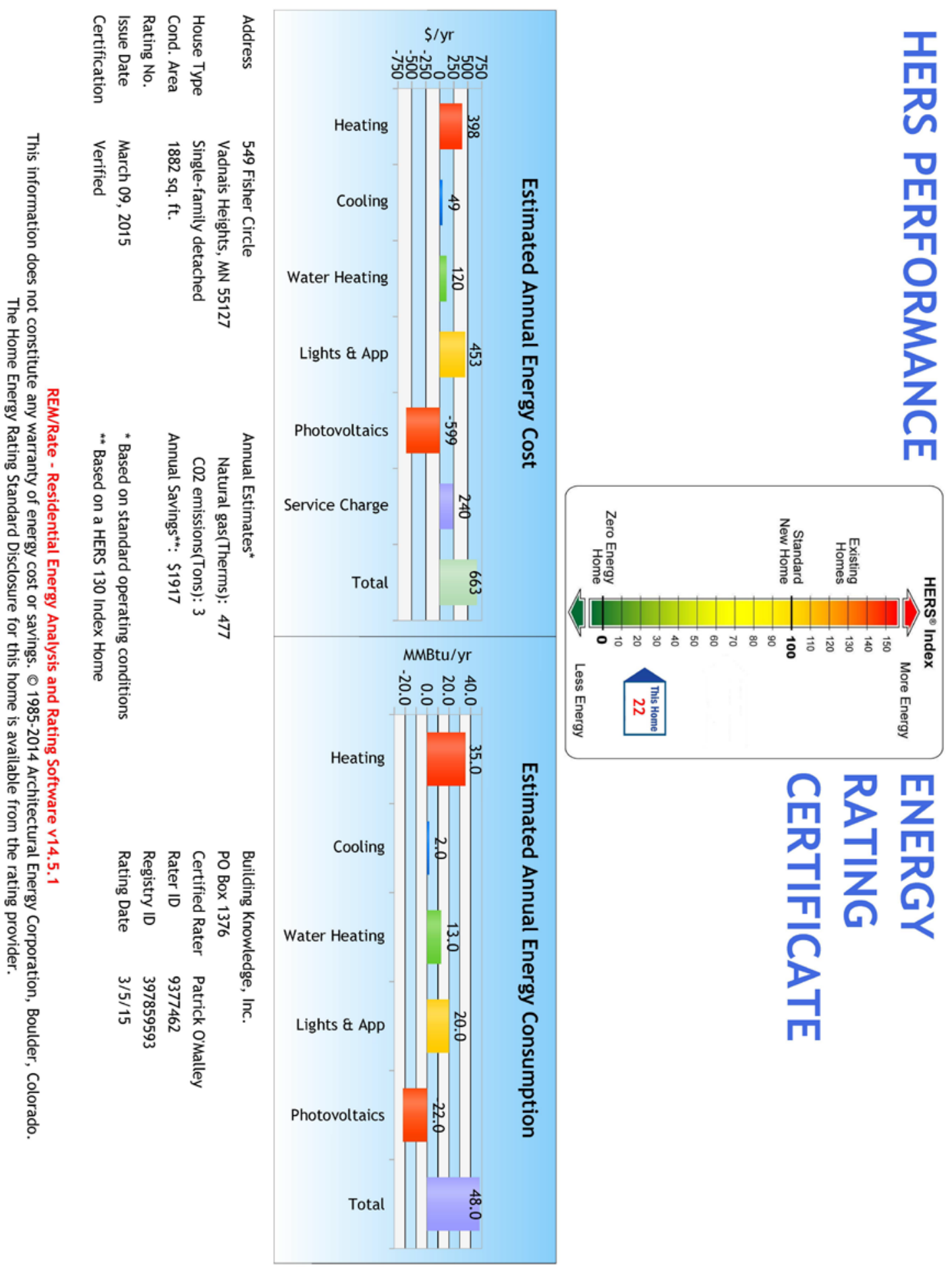




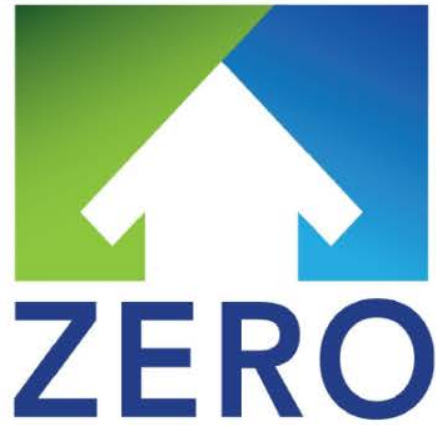

ENERGY READY HOME

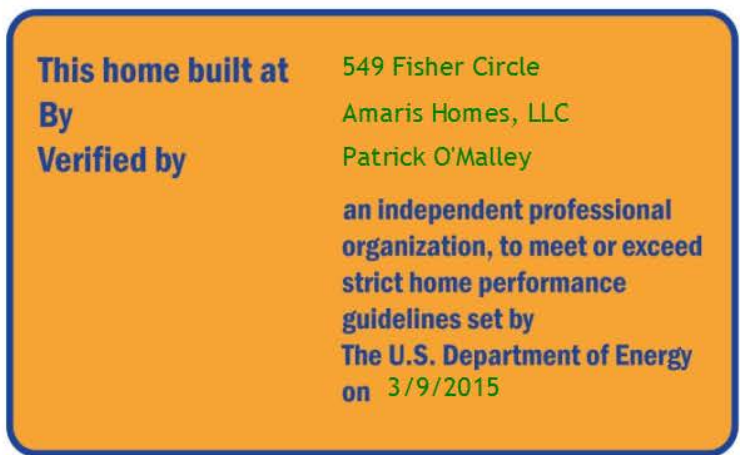

THIS HOME MEETS OR EXCEEDS THE MINIMUM CRITERIA FOR THE FOLLOWING:
YOUR HOME WAS DESIGNED, ENGINEERED, AND CONSTRUCTED IN CONFORMANCE TO U.S. DEPARTMENT OF ENERGY (DOE) GUIDELINES FOR EXTRAORDINARY LEVELS OF EXCELLENCE AND QUALITY.

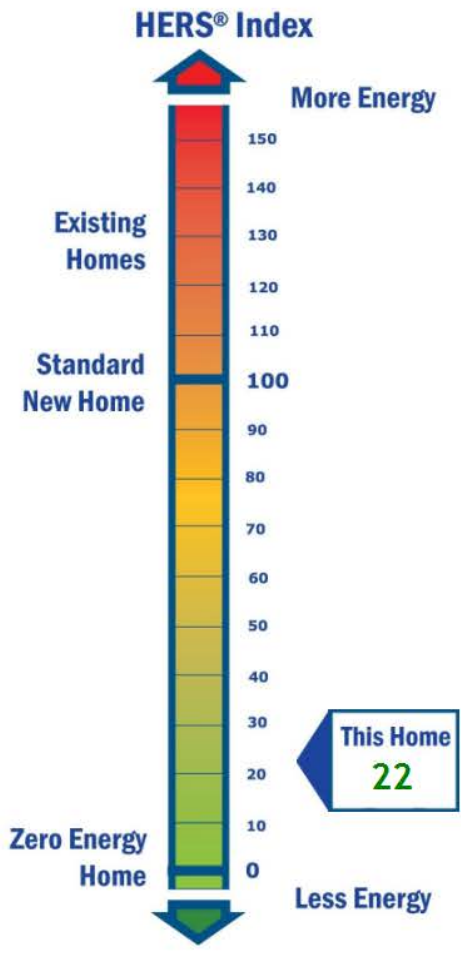

REM/Rate - Residential Energy Analysis and Rating Software v14.5.1
SAM RASHKIN, CHIEF ARCHITECT BUILDING TECHNOLOGIES U.S. DEPARTMENT OF ENERGY 


\section{DOE Zero Energy Ready Home}

\begin{tabular}{|c|c|c|c|}
\hline \multicolumn{4}{|c|}{ Optional Compliance for Builder Recognition } \\
\hline \multicolumn{4}{|c|}{ I further certify that the following also apply to this house: } \\
\hline YES & NO & $\begin{array}{l}\text { DONT } \\
\text { KNOW }\end{array}$ & Optional Home Builder Commitments for Recognition \\
\hline & $\mathrm{x}$ & & Certified under the EPA WaterSense for New Homes Program \\
\hline & $\mathrm{x}$ & & Certified under the IBHS Fortified for Safer Living Program \\
\hline & $x$ & & Followed the DOE Zero Energy Ready Home Quality Management Guidelines \\
\hline & $x$ & & $\begin{array}{l}\text { The buyer of this home signed a waiver giving DOE Zero Energy Ready Home access to utility bill data for one } \\
\text { year }\end{array}$ \\
\hline
\end{tabular}

seeking the Indoor airPLUS label must achieve full compliance with the Indoor airPLUS Verification Checklist. 


\section{DOE Zero Energy Ready Home}

\begin{tabular}{|l|l|}
\hline Energy Performance & DOE Zero Energy Ready Home Builder Partner ID\# \\
\hline House Type & 33 \\
\hline Single-family detached & Square footage of Conditioned Space including Basement \\
\hline Year built & 1882.0 \\
\hline 2014 & Square footage of Conditioned Space without Basement \\
\hline Number of Bedrooms & 1882.0 \\
\hline 3 & Registered Builder \\
\hline Site address (if not available, list the site Lot \#) & Amaris Homes, LLC \\
\hline 549 Fisher Circle & Certified Rater \\
\hline Vadnais Heights & Patrick O'Malley \\
\hline MN, 55127 & Date of Rating \\
\hline HERS Index without On-site Generation & $3 / 5 / 15$ \\
\hline 47 & Rating Software \\
\hline HERS Index with On-site Generation & REM/Rate - v14.5.1 \\
\hline 22 & Estimated annual energy costs(\$) \\
\hline HERS Index of the Target Home using size adjustment factor & 663 \\
\hline 62 & Estimated annual energy savings \\
\hline Estimated annual energy use & Electric: $9032 \mathrm{kWh} \mathrm{\} \mathrm{Natural} \mathrm{gas:} 614$ Therms \\
\hline Electric: -65 kWh \ Natural Gas: 477 Therms & Estimated annual emissions reductions \\
\hline Energy cost rates & CO2: 10.0 tons / SO2: 19.2 lbs / NOx: 24.4 lbs \\
\hline Electric: 0.09 \$ $/ \mathrm{kWh} \mathrm{\} \mathrm{Natural} \mathrm{Gas:} 0.90$ \$/Therms &
\end{tabular}

\section{DOE Zero Energy Ready Home Certification}

As the certified Rater for this house, I certify this house meets/complies with all mandatory requirments of the DOE Zero Energy Ready home guidelines, including the following:

\begin{tabular}{|c|l|}
\hline X & Compliance with all ENERGY STAR Qualified Homes Version 3 requirements and checklists \\
\hline X & Compliance with Mandatory Fenestration Requirements \\
\hline X & Compliance with Mandatory Insulation Requirements \\
\hline X & Compliance with Mandatory Duct Location Requirements \\
\hline X & Compliance with Mandatory Appliance Requirements \\
\hline X & Compliance with Mandatory Lighting Requirements \\
\hline X & Compliance with Mandatory Fan Efficiency Requirements \\
\hline X & Compliance with Mandatory EPA Indoor airPLUS \\
\hline X & Compliance with Mandatory Renewable Energy Ready Solar Electric Requirements \\
\hline X & Compliance with Mandatory Renewable Energy Ready Solar Hot Water Requirements \\
\hline & $\begin{array}{l}\text { This home was qualified via sampling in lieu of testing, in accordance with allowable sampling provisions as stated in the } \\
\text { DOE Zero Energy Ready Home National Program Requirements }\end{array}$ \\
\hline
\end{tabular}

\section{Optional Compliance for Builder Recognition}

I further certify that the following also apply to this house:

\section{\begin{tabular}{l|l|l|l|l} 
YES & NO & DONT & Optional Home Builder Commitments for Recognition
\end{tabular} \\ KNOW}

*Certification under the DOE Zero Energy Ready Home permits limited exceptions to full compliance with Indoor airPLUS. Builders seeking the Indoor airPLUS label must achieve full compliance with the Indoor airPLUS Verification Checklist. 


\section{Appendix F: Amaris Custom Homes-Vadnais Heights, Minnesota, Project BEopt Inputs}

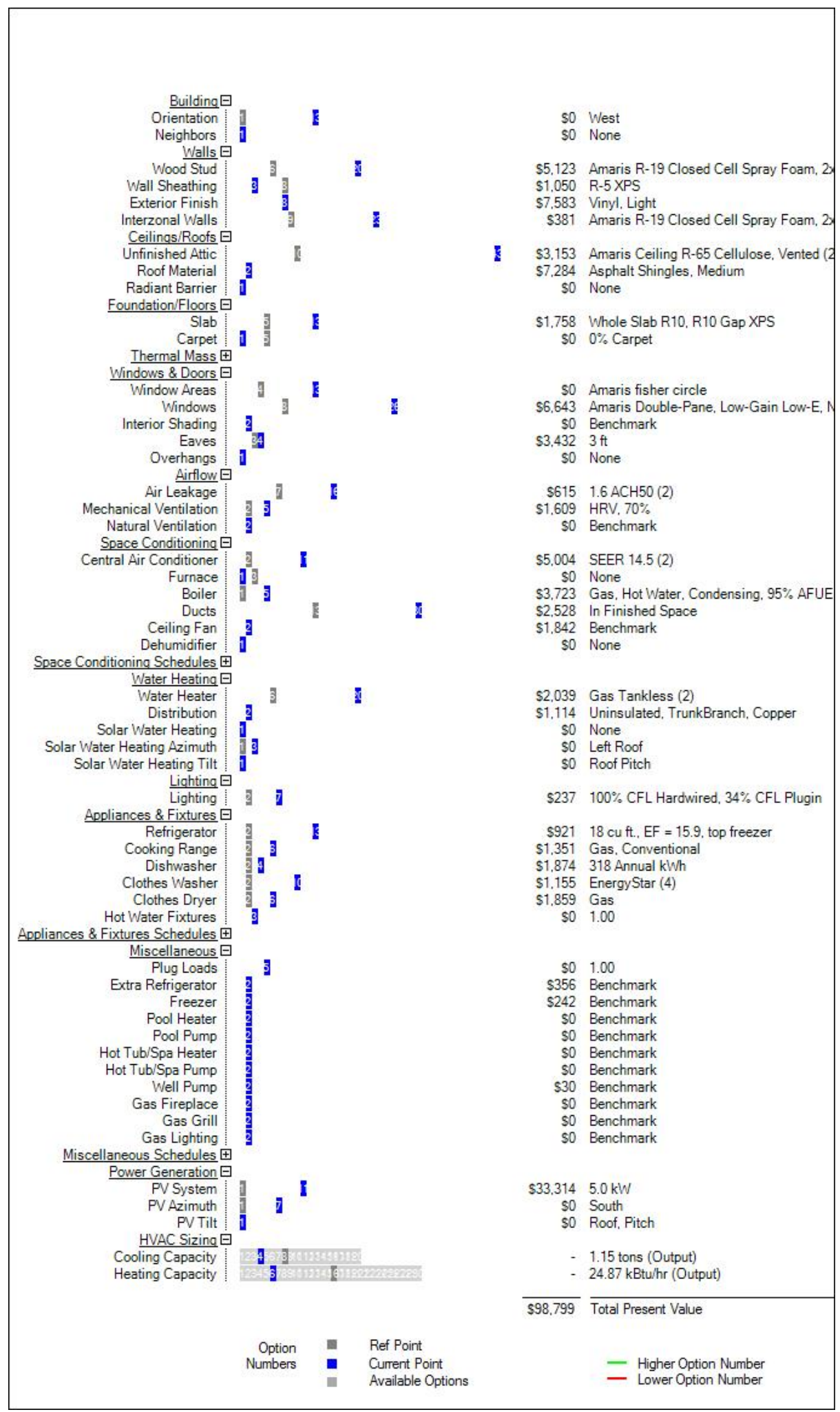




\section{Appendix G: Amaris Custom Homes-Apple Valley, Minnesota, Project HERS Reports and ZERH Certification}

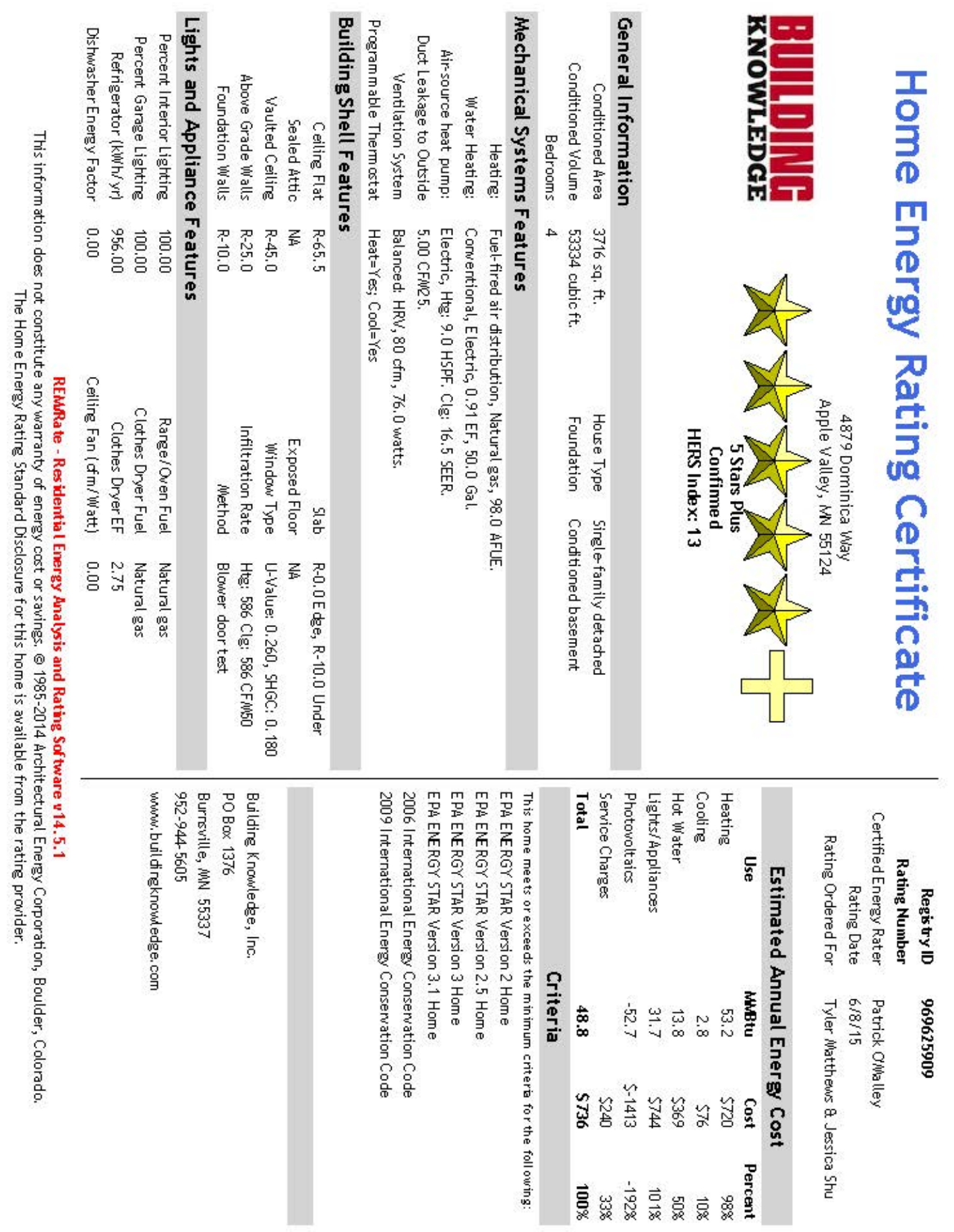




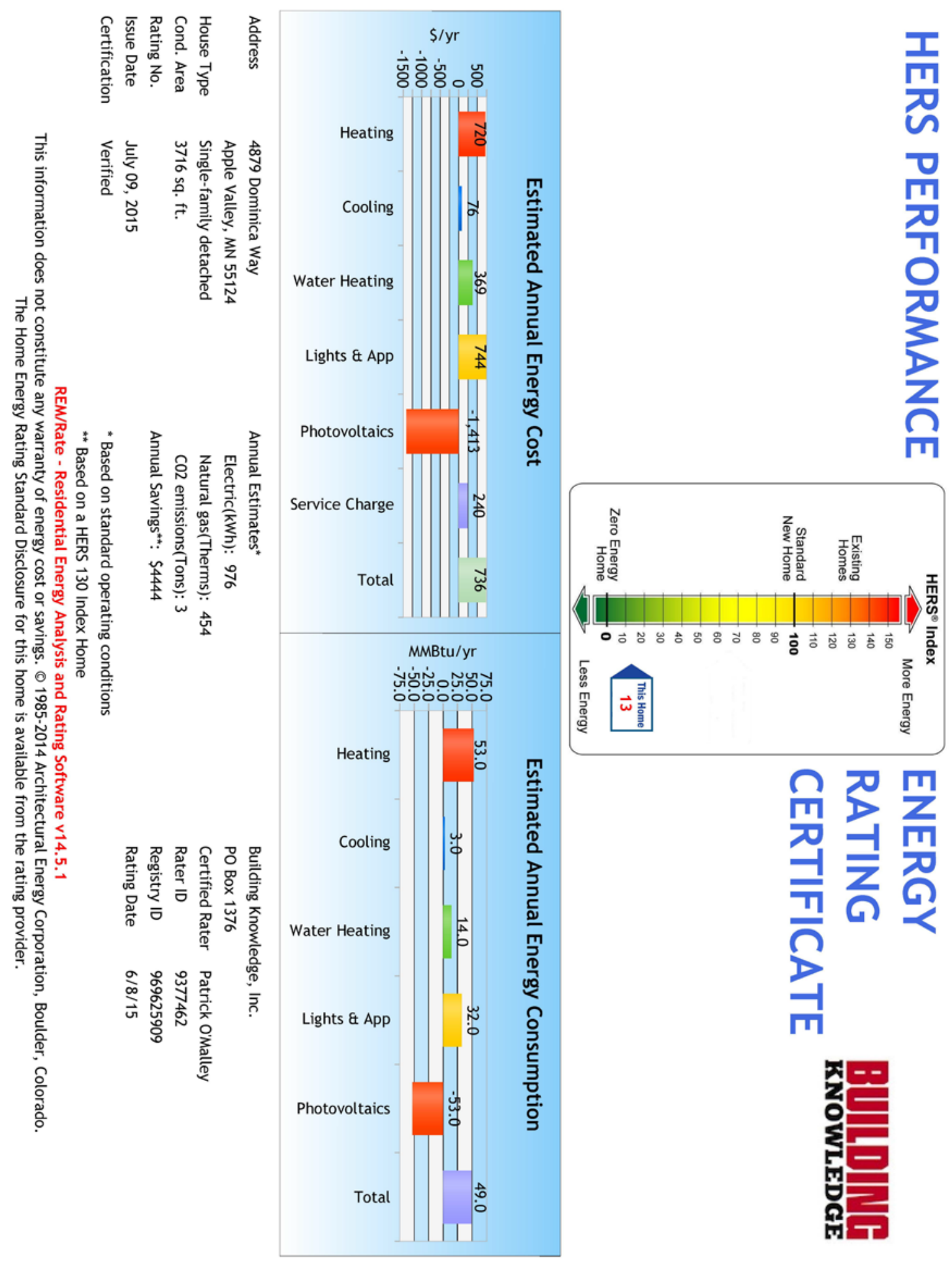




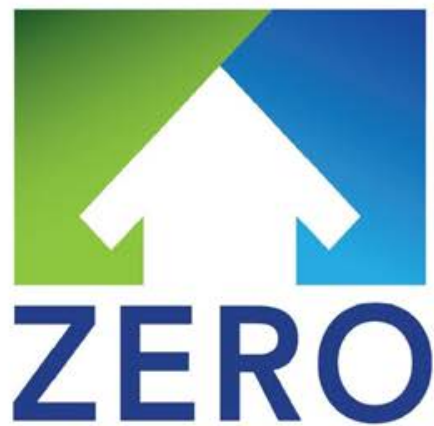

ENERGY READY HOME

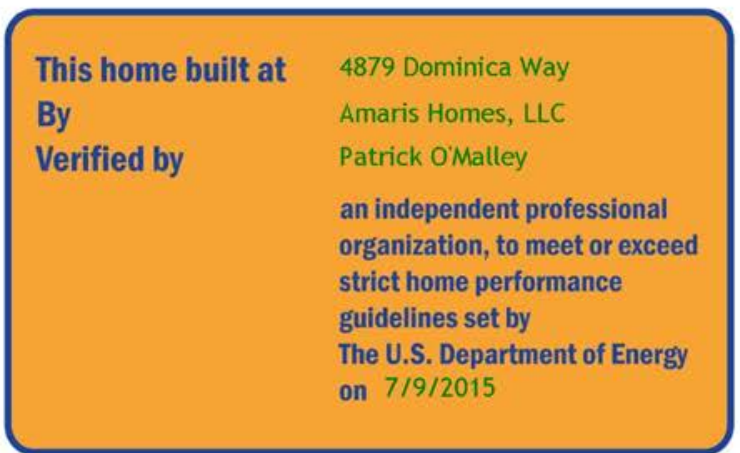

THIS HOME MEETS OR EXCEEDS THE MINIMUM CRITERIA FOR THE FOLLOWING:

\section{ENERGY READY HOME}

YOUR HOME WAS DESIGNED, ENGINEERED, AND CONSTRUCTED IN CONFORMANCE TO U.S. DEPARTMENT OF ENERGY (DOE) GUIDELINES FOR EXTRAORDINARY LEVELS OF EXCELLENCE AND QUALITY.

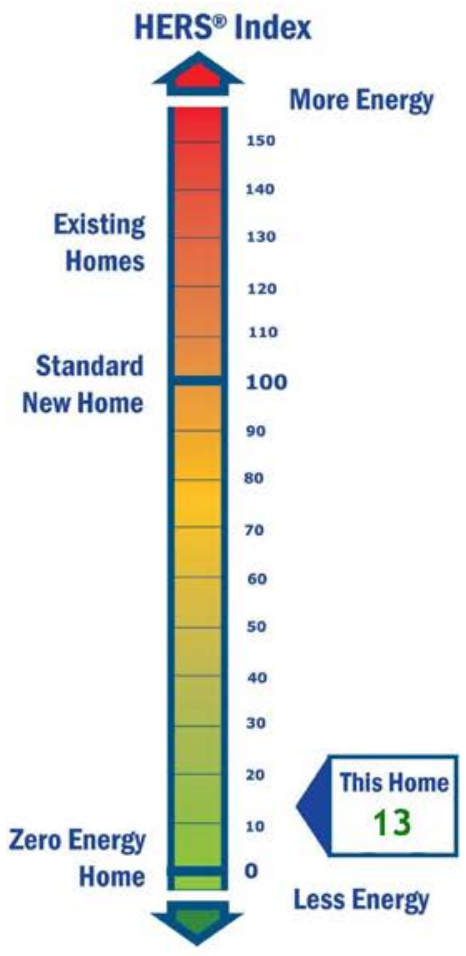

REM/Rate - Residential Energy Analysis and Rating Software v14.5.1 


\section{DOE Zero Energy Ready Home}

\begin{tabular}{|c|c|}
\hline \multicolumn{2}{|l|}{ Energy Performance } \\
\hline House Type & DOE Zero Energy Ready Home Builder Partner ID\# \\
\hline Single-family detached & 505 \\
\hline Year built & Square footage of Conditioned Space including Basement \\
\hline 2015 & 3716.0 \\
\hline Number of Bedrooms & Square footage of Conditioned Space without Basement \\
\hline 4 & 3716.0 \\
\hline Site address (if not available, list the site Lot \#) & Registered Builder \\
\hline 4879 Dominica Way & Amaris Homes, LLC \\
\hline Apple Valley & Certified Rater \\
\hline$M N, 55124$ & Patrick O'Malley \\
\hline HERS Index without On-site Generation & Date of Rating \\
\hline 46 & $6 / 8 / 15$ \\
\hline HERS Index with On-site Generation & Rating Software \\
\hline 13 & REM/Rate - v14.5.1 \\
\hline HERS Index of the Target Home using size adjustment factor & Estimated annual energy costs(\$) \\
\hline 49 & 736 \\
\hline Estimated annual energy use & Estimated annual energy savings \\
\hline Electric: 976 kWh \ Natural Gas: 454 Therms & Electric: 30572 kWh I Natural gas: 570 Therms \\
\hline Energy cost rates & Estimated annual emissions reductions \\
\hline Electric: $0.09 \$ / \mathrm{kWh} \backslash$ Natural Gas: $0.90 \$ /$ Therms & CO2: 24.8 tons / SO2: 64.8 lbs / NOx: 60.1 lbs \\
\hline
\end{tabular}

\section{DOE Zero Energy Ready Home Certification}

As the certified Rater for this house, I certify this house meets/complies with all mandatory requirments of the DOE Zero Energy Ready home guidelines, including the following:

\begin{tabular}{|c|l|}
\hline$X$ & Compliance with all ENERGY STAR Qualified Homes Version 3 requirements and checklists \\
\hline$X$ & Compliance with Mandatory Fenestration Requirements \\
\hline X & Compliance with Mandatory Insulation Requirements \\
\hline X & Compliance with Mandatory Duct Location Requirements \\
\hline X & Compliance with Mandatory Appliance Requirements \\
\hline X & Compliance with Mandatory Lighting Requirements \\
\hline X & Compliance with Mandatory Fan Efficiency Requirements \\
\hline X & Compliance with Mandatory EPA Indoor airPLUS \\
\hline X & Compliance with Mandatory Renewable Energy Ready Solar Electric Requirements \\
\hline$X$ & Compliance with Mandatory Renewable Energy Ready Solar Hot Water Requirements \\
\hline & $\begin{array}{l}\text { This home was qualified via sampling in lieu of testing, in accordance with allowable sampling provisions as stated in the } \\
\text { DOE Zero Energy Ready Home National Program Requirements }\end{array}$ \\
\hline
\end{tabular}

\section{Optional Compliance for Builder Recognition}

I further certify that the following also apply to this house:

\section{\begin{tabular}{l|l|l|l|l} 
YES & NO & DONT & Optional Home Builder Commitments for Recognition
\end{tabular} \\ KNOW}

*Certification under the DOE Zero Energy Ready Home permits limited exceptions to full compliance with Indoor airPLUS. Builders seeking the Indoor airPLUS label must achieve full compliance with the Indoor airPLUS Verification Checklist. 


\section{DOE Zero Energy Ready Home}

Optional Compliance for Builder Recognition
\begin{tabular}{|c|c|c|l|}
\hline I further certify that the following also apply to this house: \\
\begin{tabular}{|c|c|l|l|}
\hline YES & NO & $\begin{array}{l}\text { DONT } \\
\text { KNOW }\end{array}$ & Optional Home Builder Commitments for Recognition \\
\hline & $X$ & & Certified under the EPA WaterSense for New Homes Program \\
\hline & $X$ & & Certified under the IBHS Fortified for Safer Living Program \\
\hline X & $X$ & & Followed the DOE Zero Energy Ready Home Quality Management Guidelines \\
\hline
\end{tabular} \\
*Certification under the DOE Zero Energy Ready Home permits limited exceptions to full compliance with Indoor airPLUS. Builders \\
year
\end{tabular}

seeking the Indoor airPLUS label must achieve full compliance with the Indoor airPLUS Verification Checklist. 


\section{Appendix H: Amaris Custom Homes-Apple Valley, Minnesota, Project BEopt Inputs}

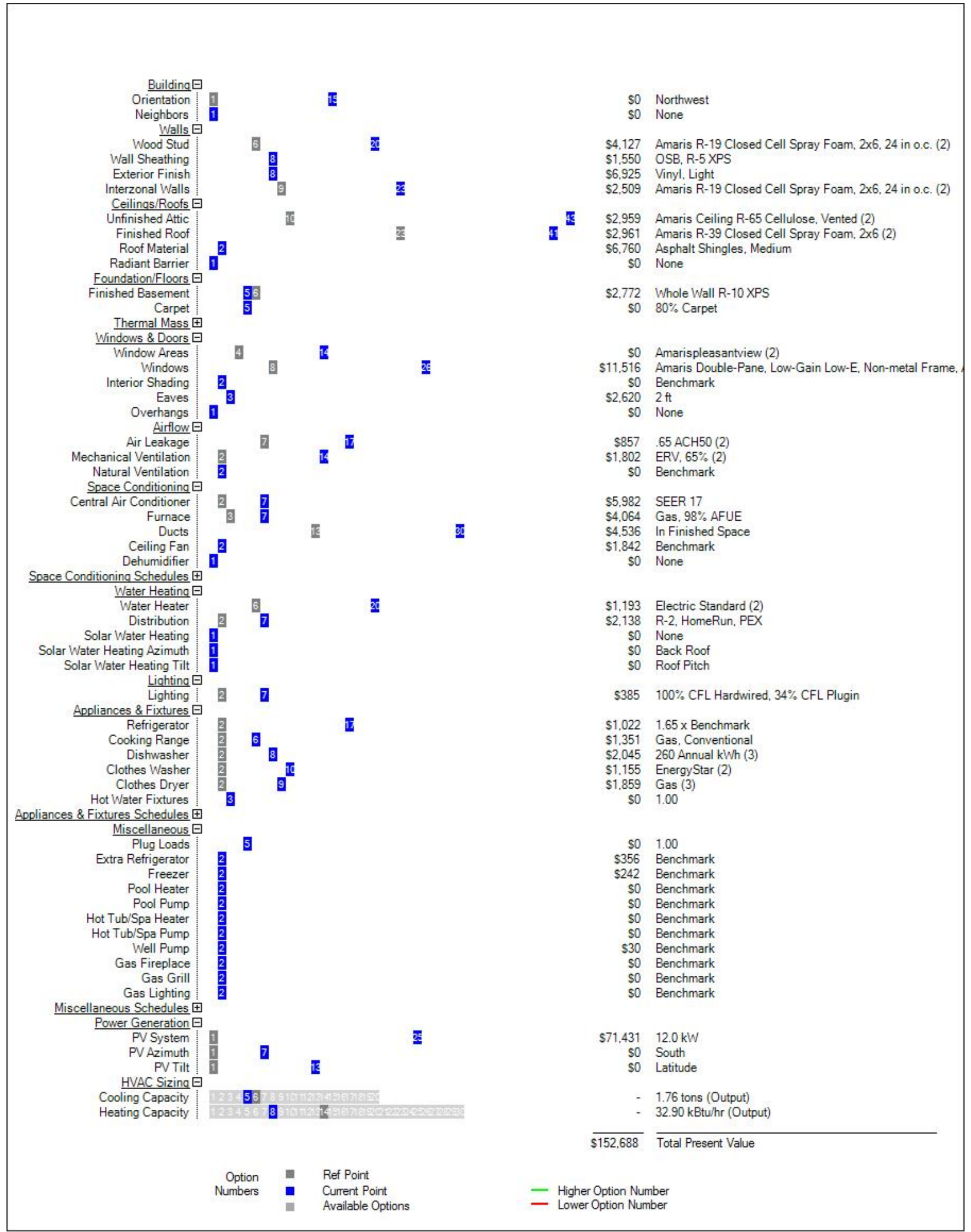

This report is available at no cost from the National Renewable Energy Laboratory (NREL) at www.nrel.gov/publications. 


\section{Appendix I: Amaris Custom Homes-White Bear Township, Minnesota, Project HERS Reports}

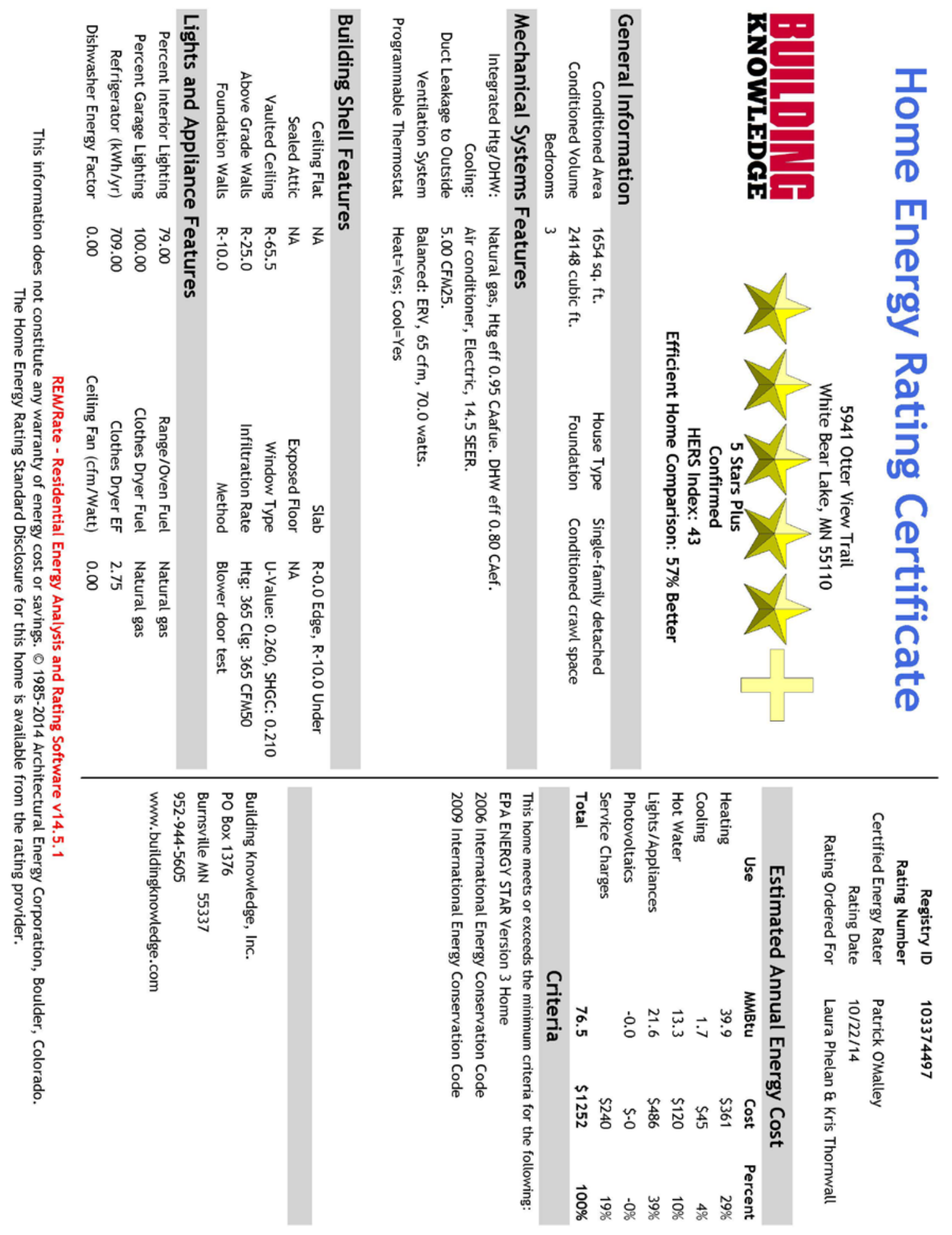




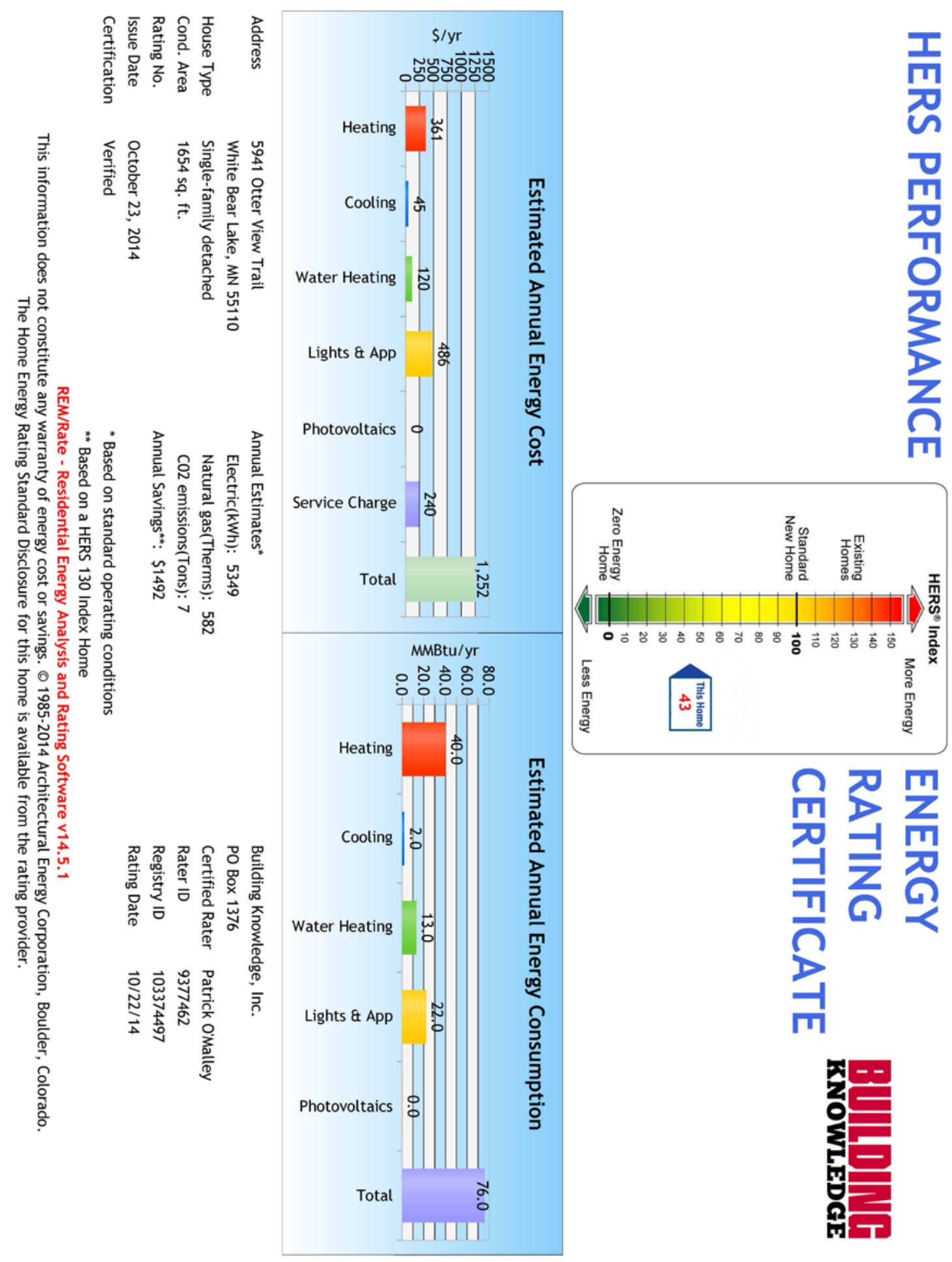




\section{Appendix J: Amaris Custom Homes-White Bear Township, Minnesota, Project BEopt Inputs}

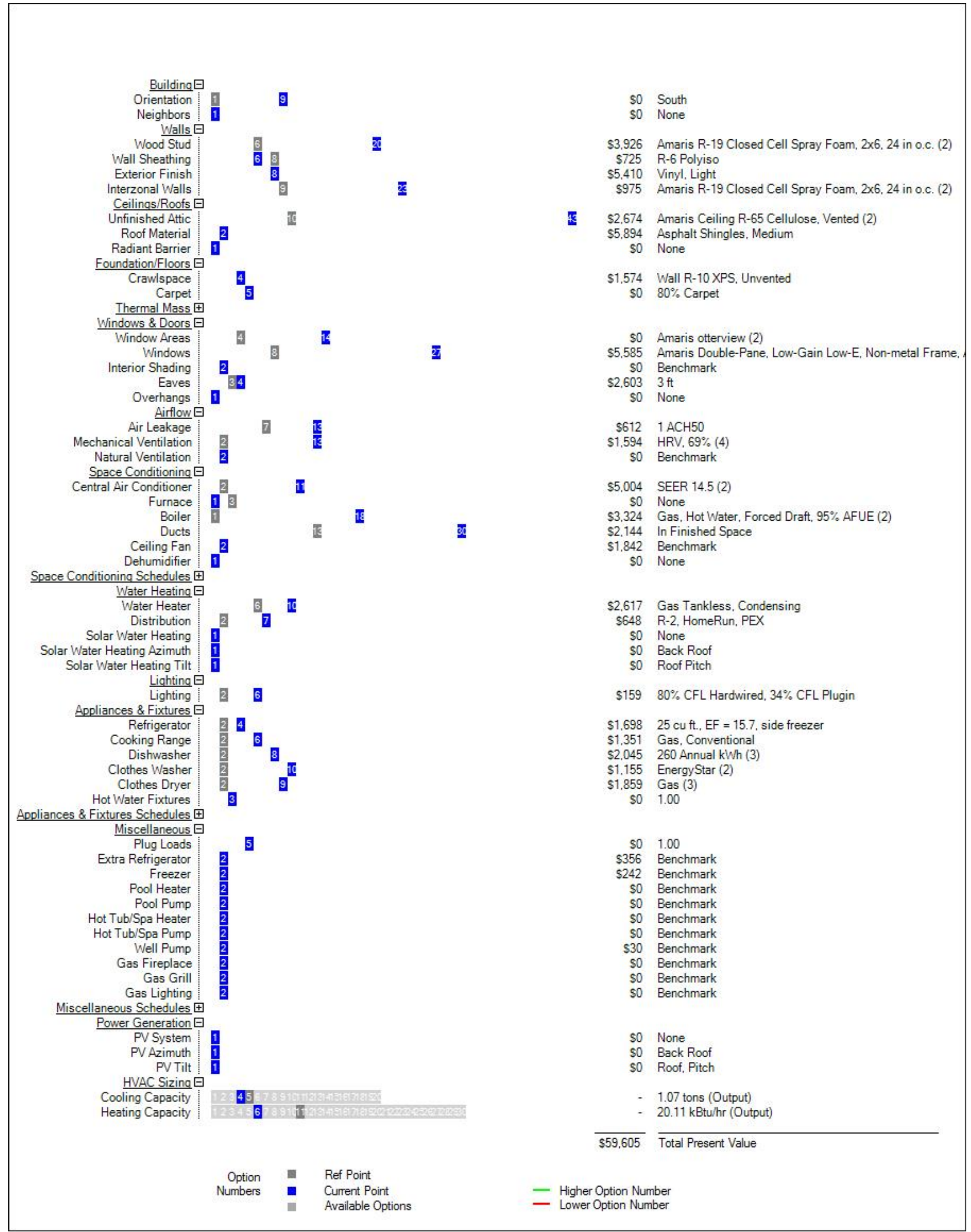




\section{Appendix K: Amaris Custom Homes-Mound, Minnesota, Project HERS Reports}

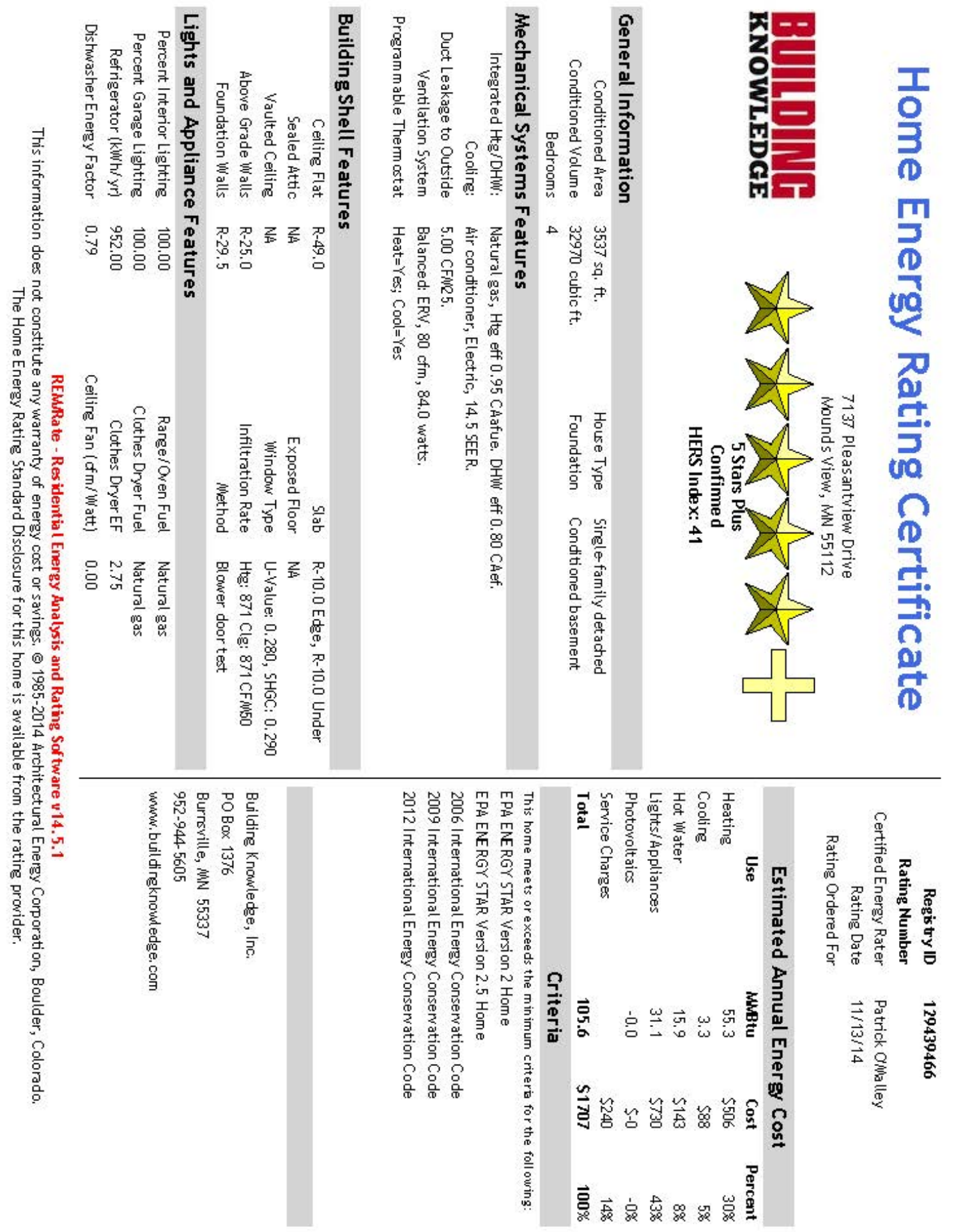




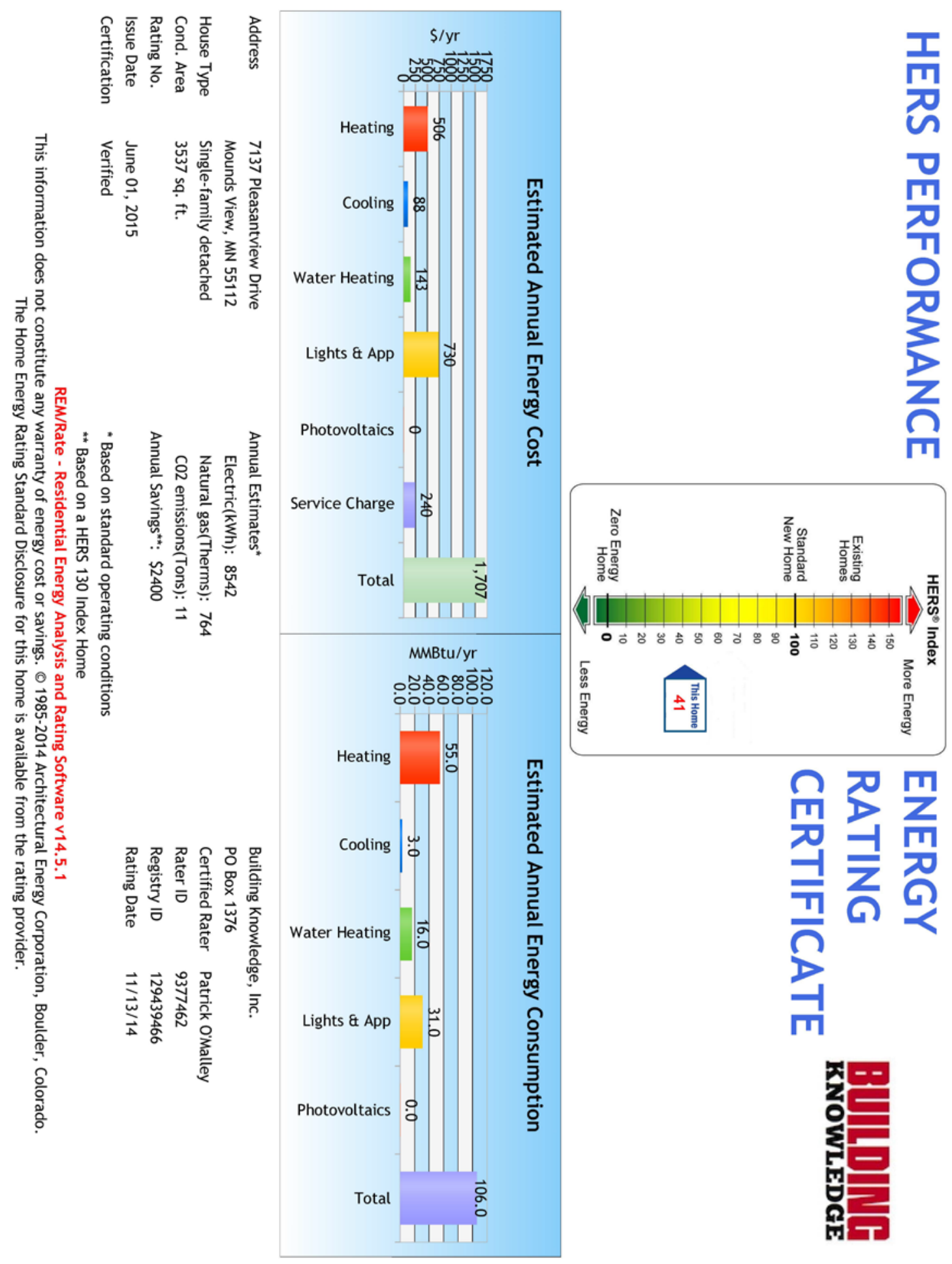




\section{Appendix L: Amaris Custom Homes-Mound, Minnesota, Project BEopt Inputs}

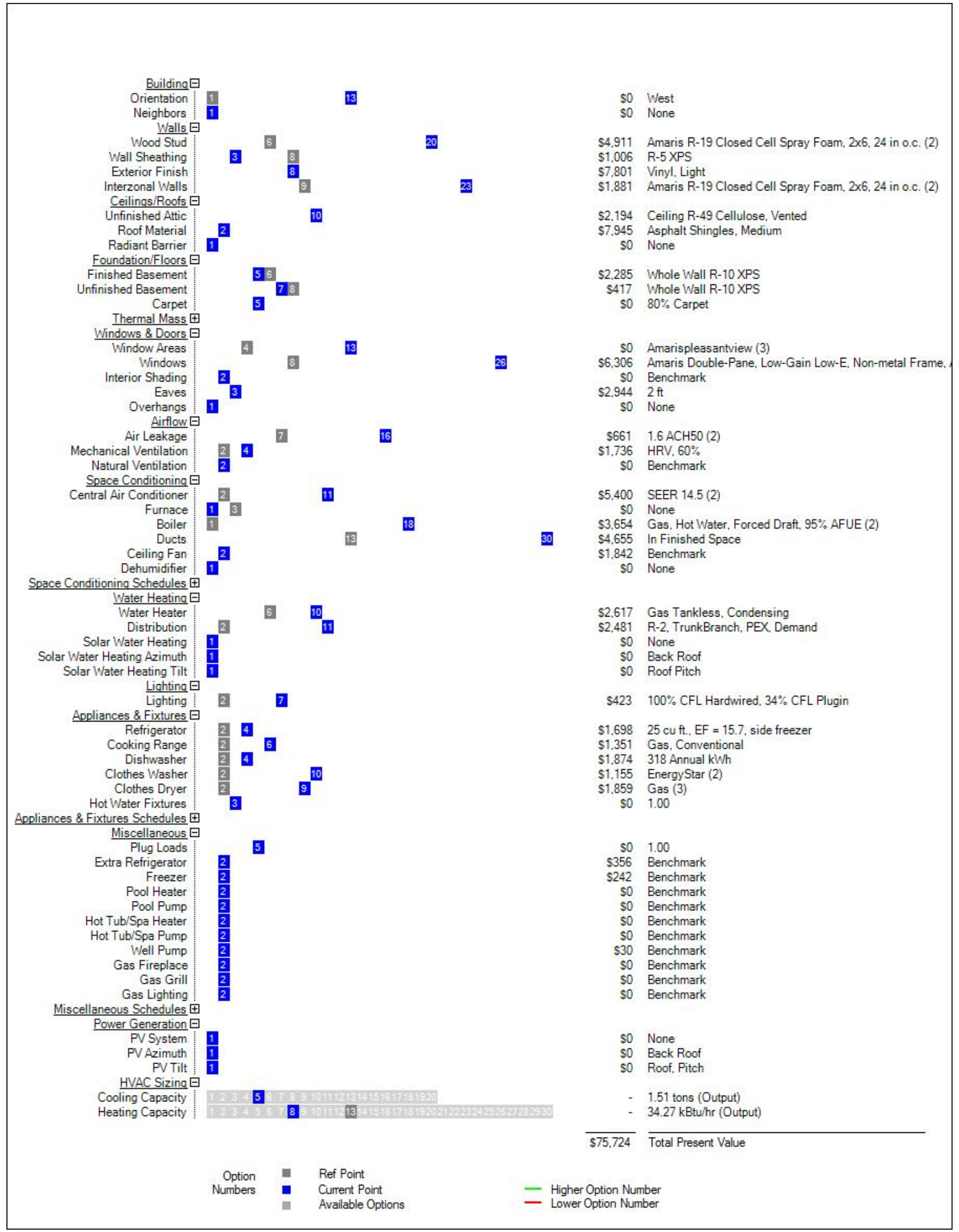




\section{Appendix M: Amaris Custom Homes-Stillwater, Minnesota, Project HERS Reports}

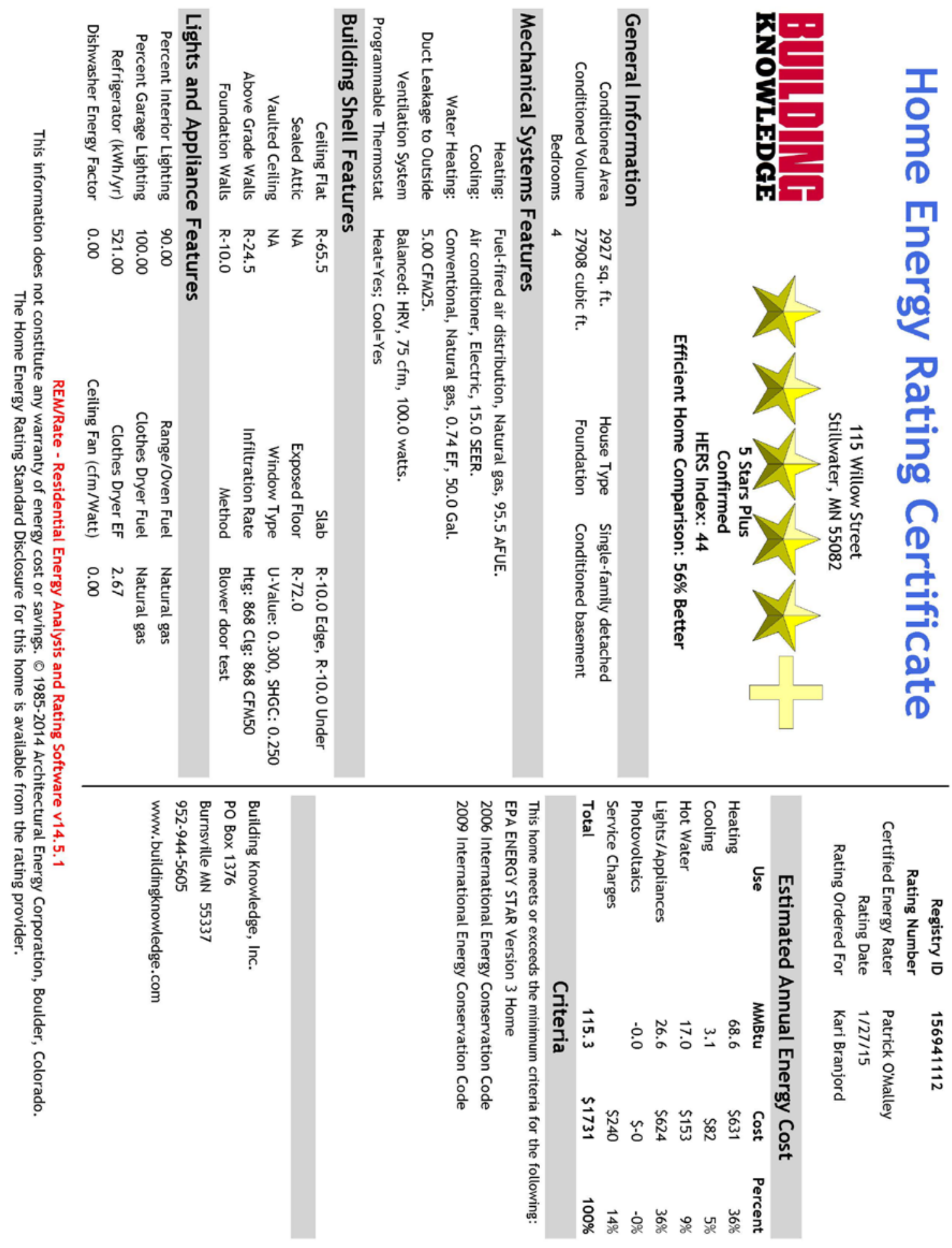




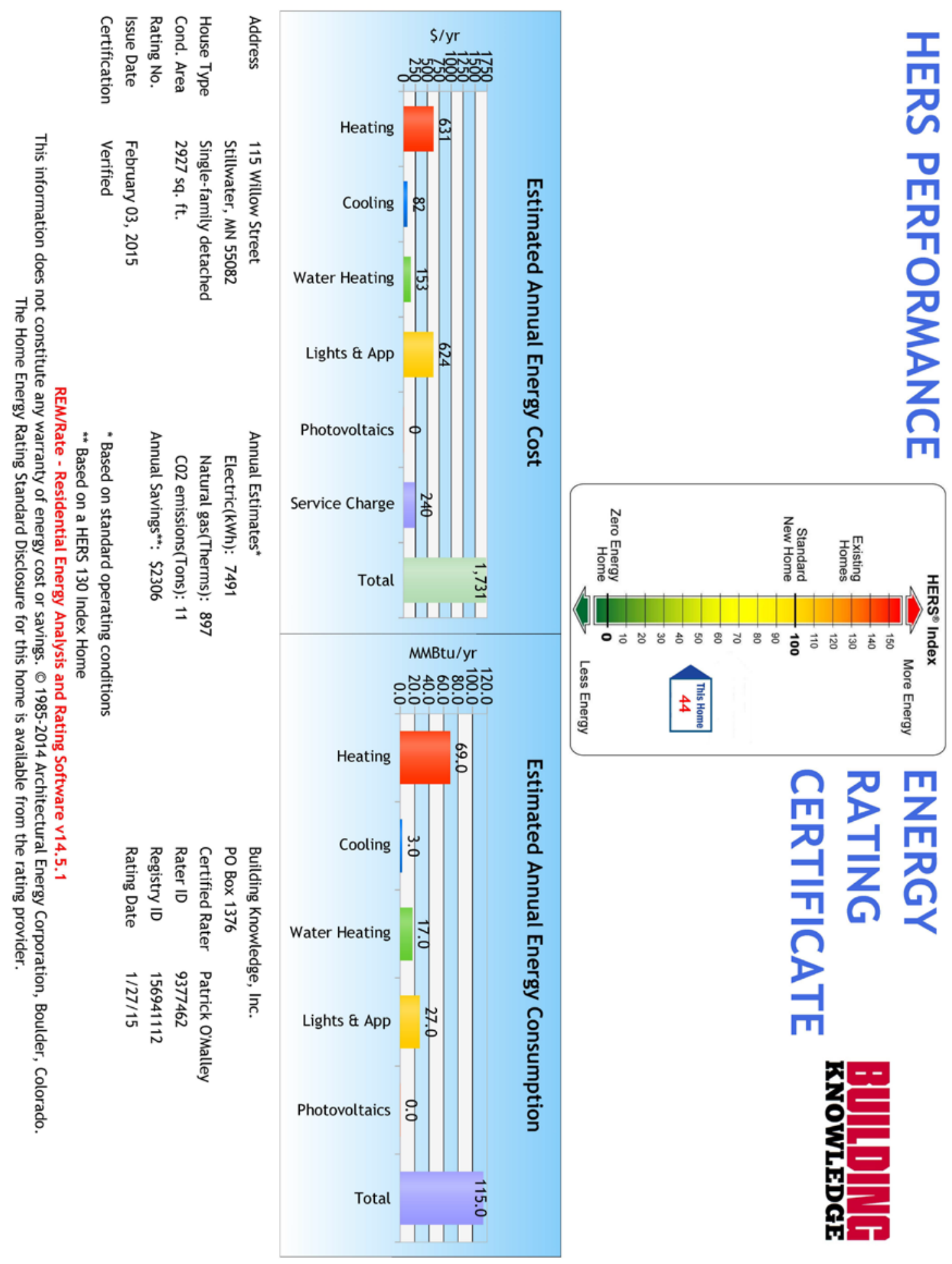




\section{Appendix N: Amaris Custom Homes-Stillwater, Minnesota, Project BEopt Inputs}

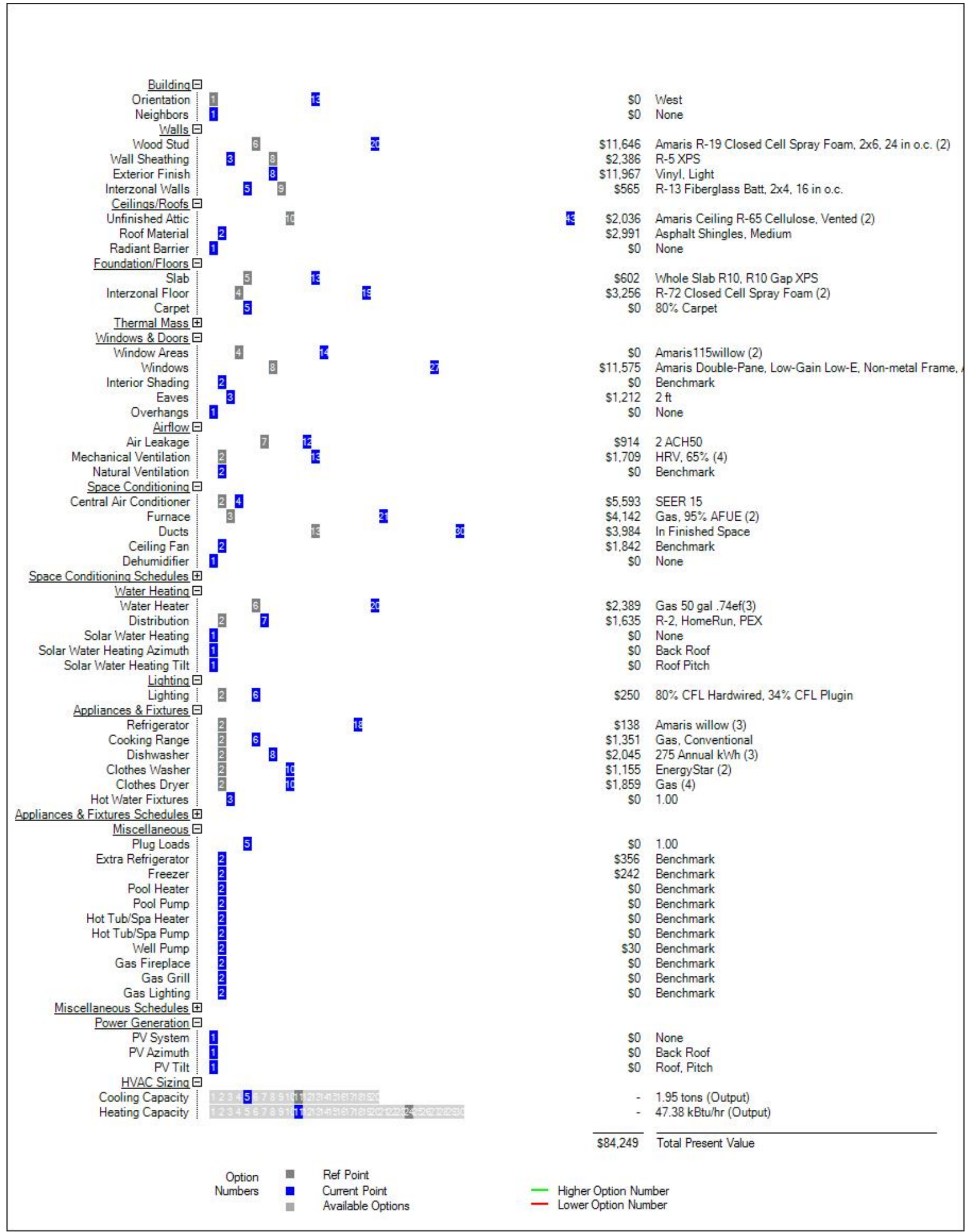




\section{Appendix O: Cobblestone Homes-Midland, Michigan, Project HERS Reports and ZERH Certification}

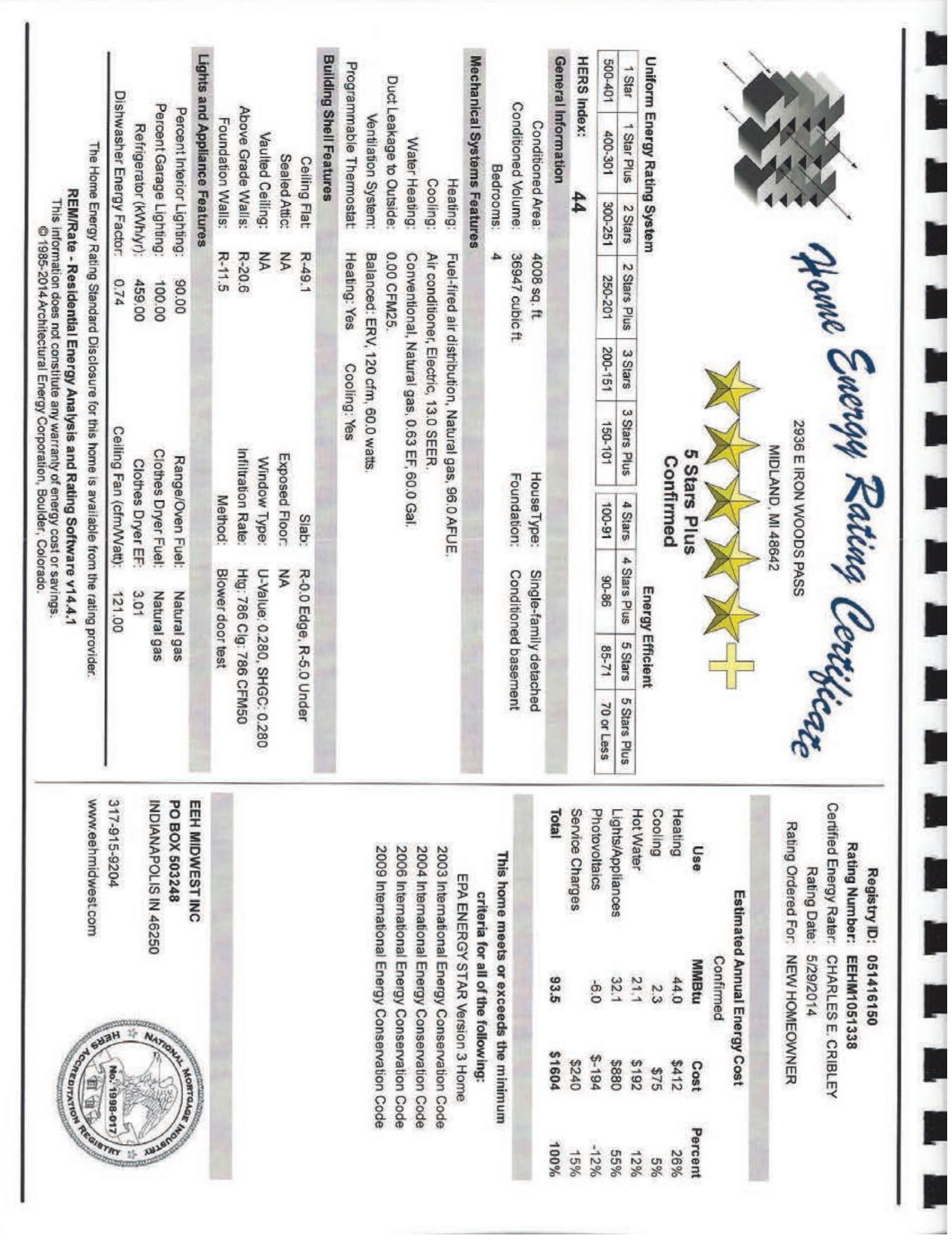




\section{Component Consumption}

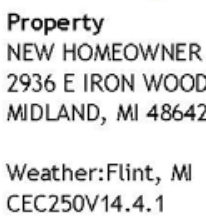

NEW HOMEOWNER

MIDLAND, MI 48642

Weather:Flint, $M !$

CEC250V14.4.1

2936 E IRON WOODS PASS

CEC250V14.4.1.blg

$\begin{array}{ll}\text { Organization } & \text { HERS } \\ \text { ENERSAFE } & \text { Confirmed } \\ 989-488-9409 & 5 / 29 / 2014 \\ \text { CHARLES E. CRIBLEY } & \text { ID: } 1362145\end{array}$

Builder

COBBLESTONE HOMES LLC

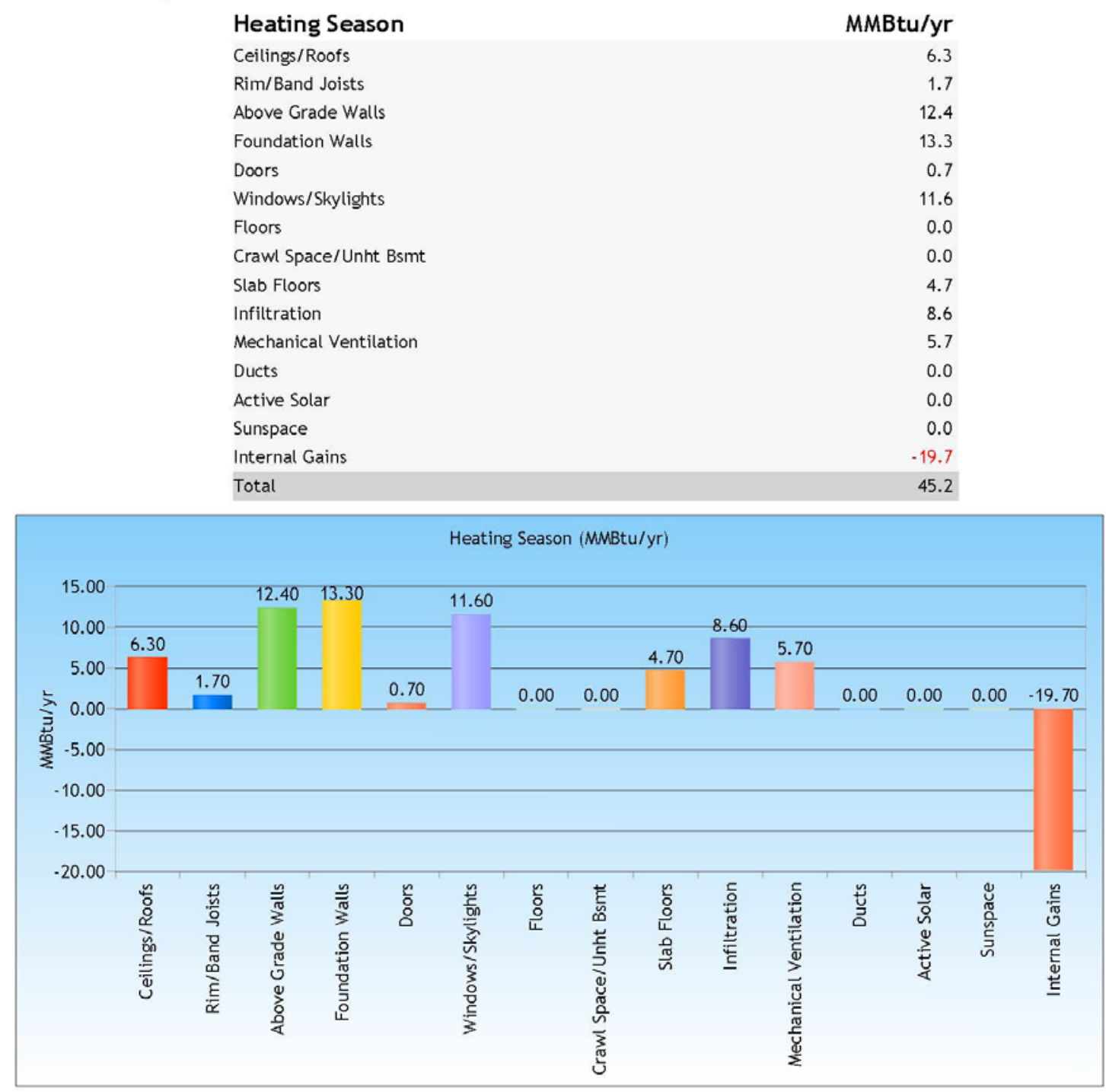

REM/Rate - Residential Energy Analysis and Rating Software v14.5.1

This information does not constitute any warranty of energy cost or savings.

(C) 1985-2014 Architectural Energy Corporation, Boulder, Colorado. 


\section{Component Consumption}

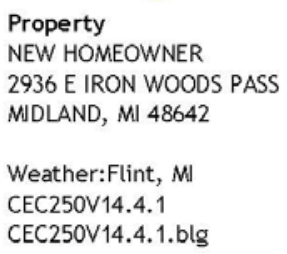

\section{Organization}

ENERSAFE

989-488-9409

CHARLES E. CRIBLEY

Builder

COBBLESTONE HOMES LLC

\section{Cooling Season}

Ceilings/Roofs

Rim/Band Joists

Above Grade Walls

Foundation Walls

Doors

Windows/Skylights

Floors

Crawl Space/Unht Bsmt

Slab Floors

Infiltration

Mechanical Ventilation

Ducts

Active Solar

Sunspace

Internal Gains

Whole House Ventilation

Total
HERS

Confirmed

$5 / 29 / 2014$

ID:1362145

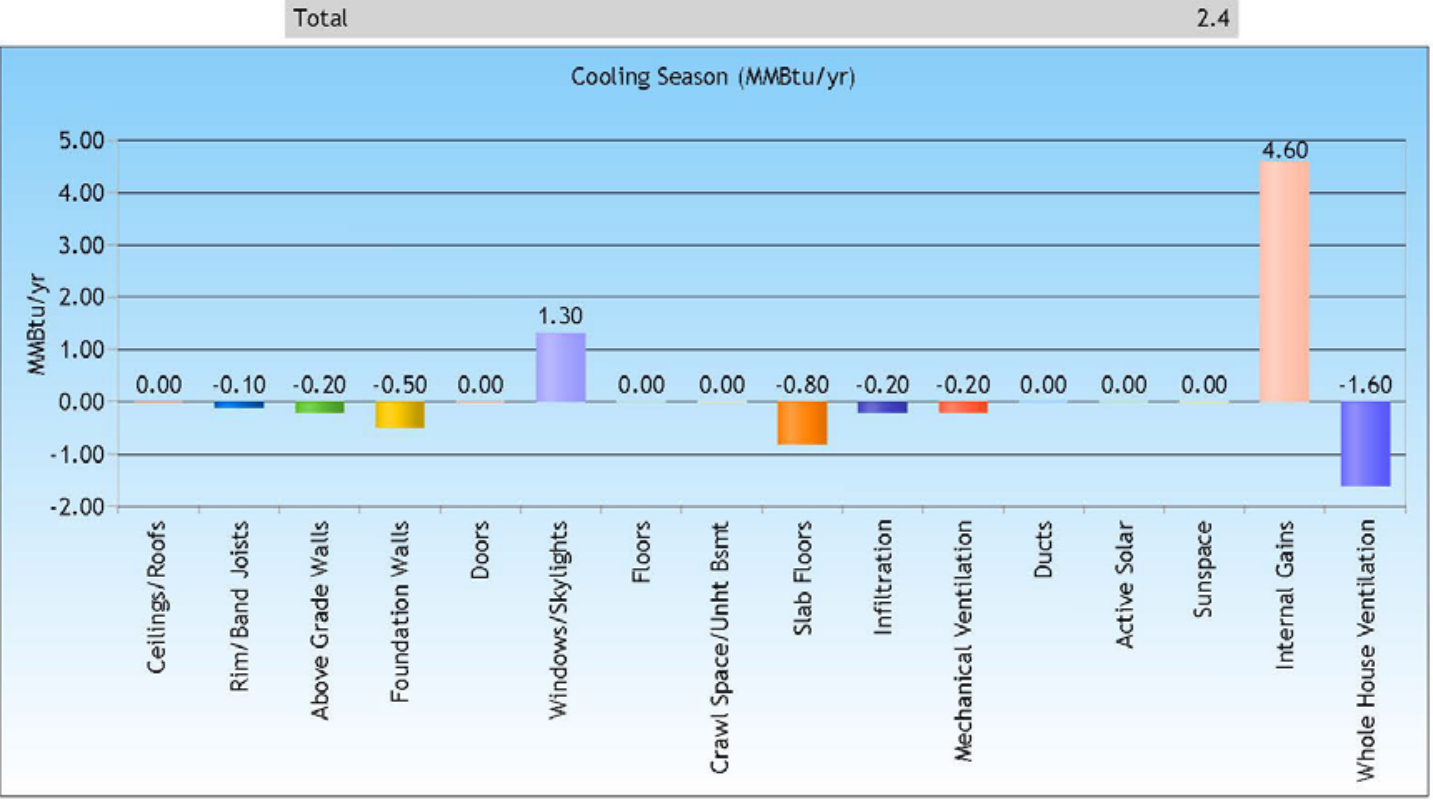

REM/Rate - Residential Energy Analysis and Rating Software v14.5.1 This information does not constitute any warranty of energy cost or savings. (C) 1985-2014 Architectural Energy Corporation, Boulder, Colorado. 


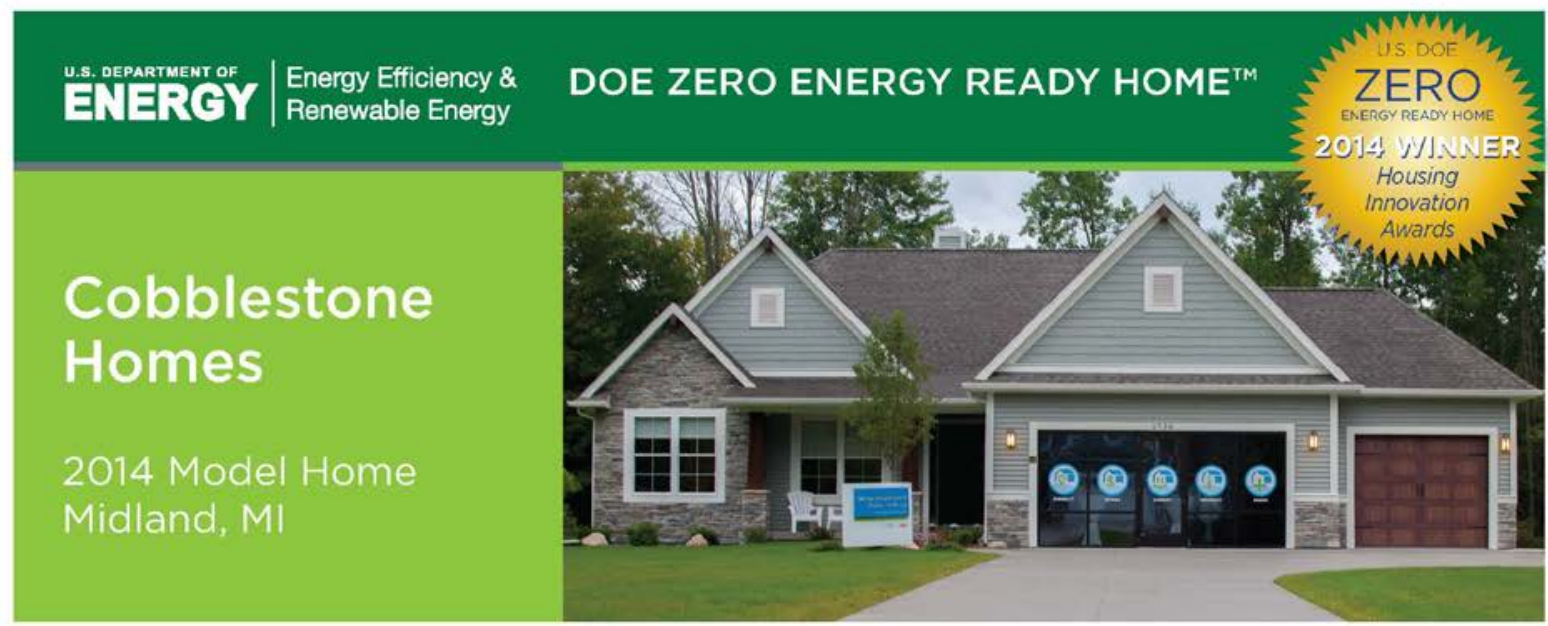

\section{BUILDER PROFILE}

Cobblestone Homes, Saginaw, MI Melissa Wahl, 989-692-0140 Melissa a cobblestonelifestyle.com www.cobblestonelifestyle.com

Rater: Enersafe, Charles Cribley chuck@ cobblestonelifestyle.com

\section{FEATURED HOME/DEVELOPMENT:}

Project Data:

- Name: 2014 Model Home

- Location: Midland, MI

- Layout: 4 bedrooms, 3.5 baths, 2 floors

- Conditioned Space: $2,745 \mathrm{ft}^{2}$ with basement

- Climate Zone: IECC 5A, cold

- Completion: May 2014

- Category: Custom

Modeled Performance Data:

- HERS Index: without PV 49, with PV 44

- Projected Annual Utility Costs: without PV $\$ 1,900$, with PV $\$ 1,706$

- Projected Annual Energy Cost Savings (compared to a home built to the 2009 (ECC): without PV \$440, with PV \$634

- Annual PV production revenue: $\$ 194$

- Builder's Added Cost Over 2009 IECC. without PV $\$ 6,000$, with PV $\$ 18,000$

- Annual Energy Savings: without PV 8,49 kWh, 799 therms natural gas, with PV $6,730 \mathrm{kWh}$
Having a homebuyer base dominated by scientists and engineers from one of the world's largest chemical companies has prompted Cobblestone Homes to stay on the cutting edge of building science. "Our homebuyers really do their research," laughs Melissa Wahl who, together with her husband Mark, founded Cobblestone Homes in Saginaw, Michigan, in 2003.

To stay ahead of their homebuyers, Cobblestone is constantly researching new home building technologies. Every year or so the company builds a prototype house to test new products and methods. In 2014, Cobblestone chose the U.S. Department of Energy's Zero Energy Ready Home criteria for its prototype home.

The DOE Zero Energy Ready Home program requires builders to meet a suite of energy, health, and durability requirements including ENERGY STAR Certified Homes Version 3.0, the U.S. Environmental Protection Agency's Indoor airPLUS and WaterSense requirements, additional DOE Zero Energy Ready Home efficiency requirements, and "renewable-ready" measures that ensure the home is ready for solar photovoltaic and water heating when the homeowner is ready to install them.

"We started out with ENERGY STAR in 2004 and that is now the minimum for every house we do. We've done an American Lung Association Healthy House and incorporated those guidelines. We did a DOE Builders Challenge Home and made it a true zero energy home with a -4 Home Energy Rating System (HERS) score," said Melissa. Cobblestone's first DOE Zero Energy Ready Home scored a HERS 49 without PV panels. "We will build more DOE Zero Energy Ready Homes. ENERGY STAR is no longer an option for us, it's assumed. I hope we will get to that point with DOE Zero Energy Ready Home," said Melissa.

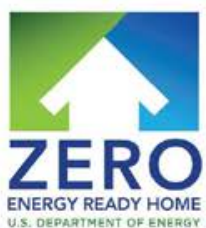

The U.S. Department of Energy invites home builders across the country to meet the extraordinary levels of excellence and quality specified in DOE's Zero Energy Ready Home program (formerly known as Challenge Home). Every DOE Zero Energy Ready Home starts with ENERGY STAR Certified Homes Version 3.0 for an energy-efficient home built on a solid foundation of building science research. Advanced technologies are designed in to give you superior construction, durability, and comfort; healthy indoor air; high-performance HVAC, lighting, and appliances; and solar-ready components for low or no utility bills in a quality home that will last for generations to come. 


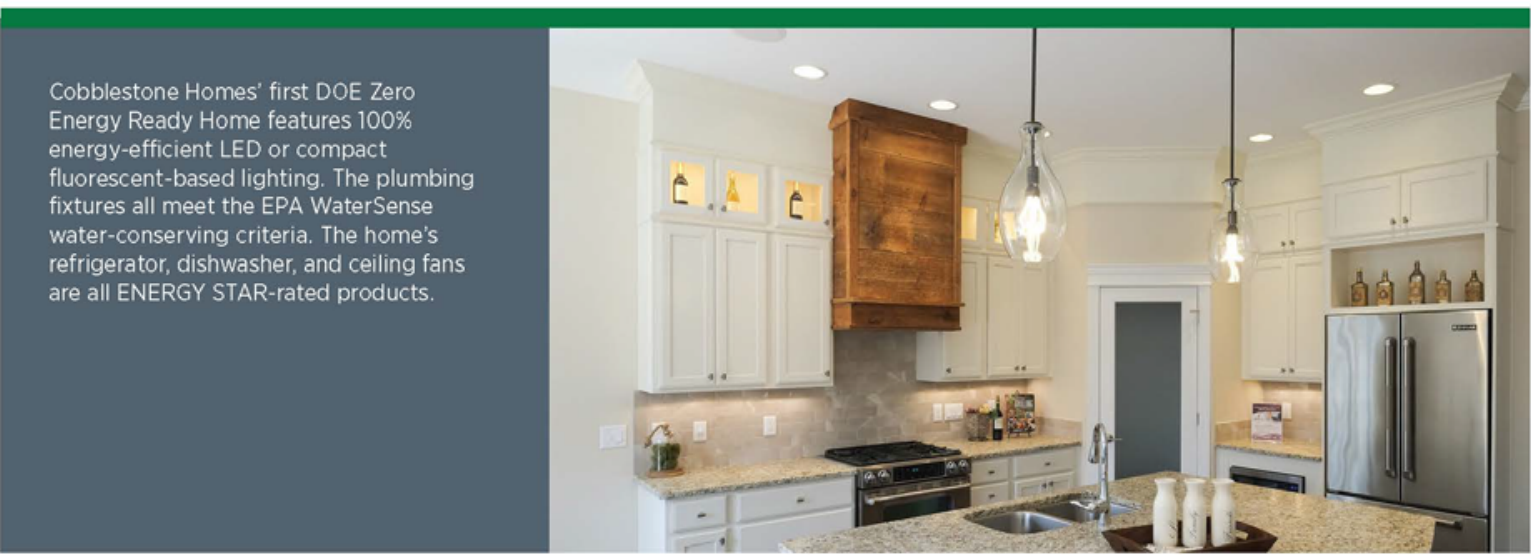

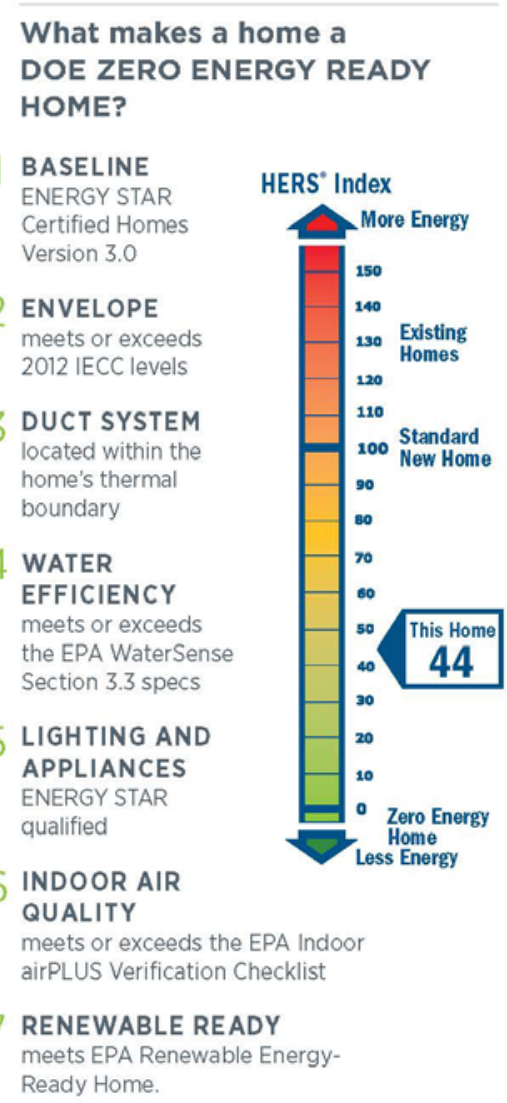

The family-run business of 15 full-time staff and over 125 dedicated subs builds about 50 to 60 homes a year. Cobblestone's first DOE Zero Energy Ready Home is a 2,745- $\mathrm{ft}^{2}$, 4-bedroom, 3.5-bath home with a full basement. The home is located in Midland, Michigan, headquarters of DOW Chemical, which provided solar photovoltaic roofing shingles for the home and is conducting a year's worth of energy monitoring. The home is being used as a demonstration home while monitoring is going on, with displays of energy-efficient technologies set up in the garage.

Cobblestone has partnered with DOW and other building science researchers on previous homes. Cobblestone attempts to collect data every three years on each house they have built. They take the unusual step of offering a contest to their homeowners. Homeowners are asked to submit 12 months of energy bills. Cobblestone analyzes the bills and the homeowner who beats their estimated usage by the most wins $\$ 3,000$ or a trip to Disneyland. "This contest allows us to verify after-occupancy performance," said Melissa.

More than 5,000 people toured Cobblestone's previous DOE Builders Challenge home. Over 400 people have already toured the DOE Zero Energy Ready Home between May and July 2014, including prospective homeowners, members of the media, realtors, college students in construction programs, other builders, vendors, boy scout troops, and interested members of the community.

Visitors to the home will notice the home's numerous double-pane, argon-filled, PVC-framed windows. They probably won't notice the windows' low-emissivity coatings, which minimize the amount of heat transferring through the glass. They are sure to notice the eye-catching modern folk art lighting fixtures. They may not know that they use $100 \%$ high-efficiency light sources, either LED or compact fluorescent lamps. And they may not suspect that each of the home's four ceiling fans are ENERGY STAR rated, as are the refrigerator and dishwasher.

Another barely visible but highly notable feature is the $1.4 \mathrm{kWs}$ of photovoltaic (PV) roof tiles. The PV tiles are made of a flexible material that has the same dimensions and thickness as asphalt shingles. Rather than sit-on-top panels, the tiles are integrated with the shingles as part of the roofing layer. The home's roof structure and orientation on the lot were designed to allow room for up to 891 $\mathrm{ft}^{2}$ of PV tiles and/or of solar thermal water heating panels should a solar water heating system be desired in the future. 


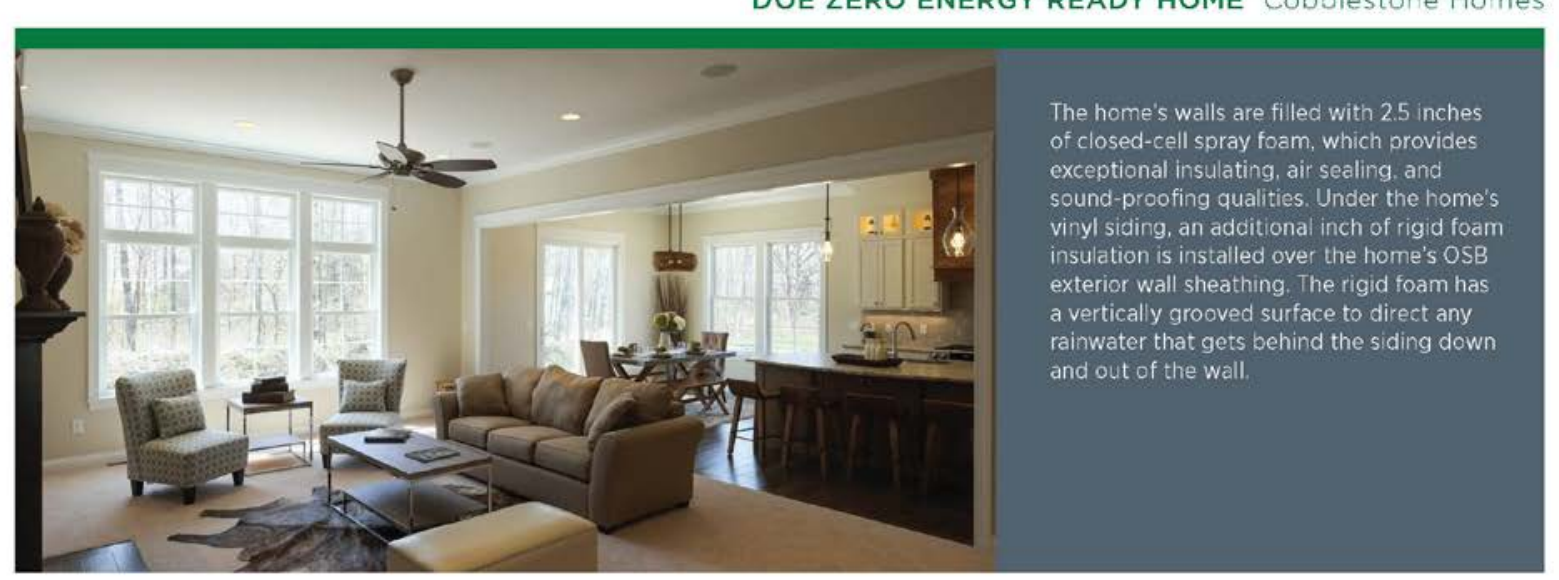

The plumbing fixtures in the kitchen and bathrooms are all compliant with the EPA WaterSense program's strict criteria for water efficiency. A button on the bathroom wall triggers a recirculation pump to ensure you won't wait more than 30 seconds for hot water at the tap.

The home's $96 \%$ efficient gas furnace and 2.5-ton 13 SEER air conditioner with variable-speed ECM motor are located in the basement. The furnace and water heater are sealed combustion, direct-vent appliances for safe, efficient operation.

Some of the most impressive energy-efficiency features of the home are the ones visitors never see. Beneath the 9 -foot poured concrete foundation walls, the footings were covered with a painted-on water seal product to form a capillary break. The concrete walls were water-proofed on the exterior and then covered with a 1 -in. vertically grooved moisture-resistant extruded polystyrene rigid foam, which serves as both a drainage board and insulation layer. The interior of the basement walls was insulated with the same 1 -in. foam board to provide a total basement wall R-value of R-11.5. This board aids in directing water down to the perimeter drain tiles located both inside and outside of the foundation so that water can be directed away from the structure.

Cobblestone Homes would typically install 2 inches of rigid foam on the outside of the foundation wall and no foam on the inside in new construction, but they chose to put 1 inch on either side in the model home to show visiting remodelers the interior installation option. Cobblestone selected a foam product that does not require a "thermal break" ignition barrier. Most foam insulations must be covered with an ignition barrier like drywall because they can burn or melt when exposed to flame.

If visitors could peek into the above-grade walls, they would see that the $2 \times 416$ inch on center stud-framed exterior walls have 1 inch of XPS rigid foam installed over the OSB exterior wall sheathing. All of the seams in the foam are sealed with tape to form a water-tight barrier so house wrap is not needed, which saves the builder time and money. Cobblestone uses a felt paper house wrap and plastic mesh rain screen only on those portions of the exterior walls where brick and stone will be installed. The wall cavities are then insulated from the inside with $2.5+$ inches of closed-cell polyurethane spray foam. The spray foam provides insulation, air sealing, and strength to the walls, which Cobblestone feels can help the home resist high winds. The wall framing is nailed and glued together with two beads of construction adhesive or caulk at every wood-to-wood joint.

\section{HOME CERTIFICATIONS}

DOE Zero Energy Ready Home Program

ENERGY STAR Certified Homes

Version 3.0

EPA Indoor airPLUS

EPA WaterSense
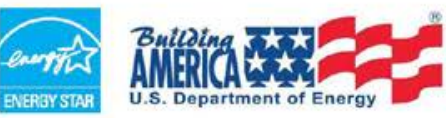

Every DOE Zero Energy Ready Home combines a building science baseline specified by ENERGY STAR Certified Homes with advanced technologies and practices from DOE's Building America research program. 
A foam sill seal stops moisture transmission between the foundation wall and the bottom plate. Cobblestone also employs an airtight drywall approach, applying a bead of construction adhesive under the drywall at all studs.

Because Cobblestone installed the HVAC equipment and ducts in the basement, they chose a vented attic where insulation is installed on the ceiling plane. Cobblestone designs their attics with a raised-heel truss so that there is more height at the eaves to pile more insulation over the tops of the walls. First, closed-cell polyurethane foam is sprayed into the eaves to air seal and insulate the space above the outer-wall top plates from the ceiling deck to the attic ventilation baffles Then 15 to 16 inches of blown cellulose is piled onto the flat portion of the attic deck for an attic R-value of R-49.

The spray-foamed walls, top plate, and sill plate and additional air sealing of any holes through the ceiling provide for a very airtight building shell. Blower door testing showed the home had 1.65 air changes per hour at 50 Pascals of pressure difference, far below the $7 \mathrm{ACH} 50$ limit for whole-house air leakage set by the 2009 International Energy Conservation Code (IECC). To ensure that the home has fresh, healthy indoor air, an energy recovery ventilator (ERV) was installed in the basement. The ERV has ducts to bring fresh air in from outside and to exhaust stale air to the outside. The air streams cross in a heat exchanger that allows the warmer air path to transfer heat to the cooler path. The incoming air is routed to the HVAC system's central air handler for distribution through the home.

Melissa points to air sealing as an area that challenged Cobblestone's crews to improve their technique over the years. HVAC was another area where Cobblestone pushed for improvement. "Our HVAC contractor really fought us on heating and cooling equipment sizing. They said 'we've never put in a furnace that small.' We had to put in their contract that we would pay them to change out the furnace if there were any comfort issues. Now they are firm believers in what we are doing but it's taken 7 years."

Cobblestone enjoys the challenge of continuous improvement, which is one reason they were eager to try a DOE Zero Energy Ready Home. "We are always looking for something to push us," said Melissa. Cobblestone's comprehensive system of quality checks helps to ensure that new practices will be implemented successfully. Cobblestone goes beyond the thermal by-pass checklists. The project management team inspects daily with more formal inspections done at framing, insulation, drywall, rough in, finish mechanicals, and at the end of construction on fit and finish materials. "We meet twice a week to discuss schedule and improvement opportunities for process, production, and material usage," said Melissa.

During the construction process, homeowners participate in various home construction tours - two of which are strictly to educate the homebuyer on Cobblestone's building practices and on the care and maintenance of high-performance homes. "These formal tours give our homeowners a true understanding of their new home's exceptional construction quality," said Melissa. "They often share this experience with friends and colleagues. The majority of our business comes from these referrals!"

Photos courtesy of Cobblestone Homes.

\section{KEY FEATURES}

- DOE Zero Energy Ready Home Path: Performance

- Walls: $2 \times 416$-inch o.c. framing, 2.5 inches (R-12) closed-cell spray-foam cavity insulation; 1-in. taped, grooved XPS rigid foam over OSB sheathing

- Roof: Vented attic, raised heel trusses with closed-cell spray foam over top plate from ceiling deck to baffles, 15-in. blown cellulose

- Foundation: Poured concrete basement walls insulated on inside and outside with taped, grooved XPS rigid foam; waterproofing on exterior under rigid foam and separating footing from walls. 1 -in. XPS rigid foam under the basement slab

- Windows: Double-pane, argon-filled, low-e, PVC-framed, $\mathrm{U}=0.28, \mathrm{SHGC}=0.28$

- Air Sealing: 1.65 ACH 50

- Ventilation: ERV connected to central HVAC

- HVAC: $96 \%$ effic, sealed combustion gas furnace and 2.5-ton 13 SEER AC with ducts in conditioned basement

- Hot Water: 60-gal tank water heater in basement, $0.63 \mathrm{EF}$, recirc loop, PEX piping

- Lighting: $100 \%$ LED and CFL

- Appliances: ENERGY STAR-rated dishwasher, refrigerator, four ceiling fans

- Solar: 1.44-kW roof-integrated PV shingles; conduit installed and roof designed with optimal orientation for solar thermal panels and additional PV panels

- Water Conservation: EPA WaterSense showerheads, faucets, toilets 


\section{Appendix P: Cobblestone Homes-Midland, Michigan, Project BEopt Inputs}

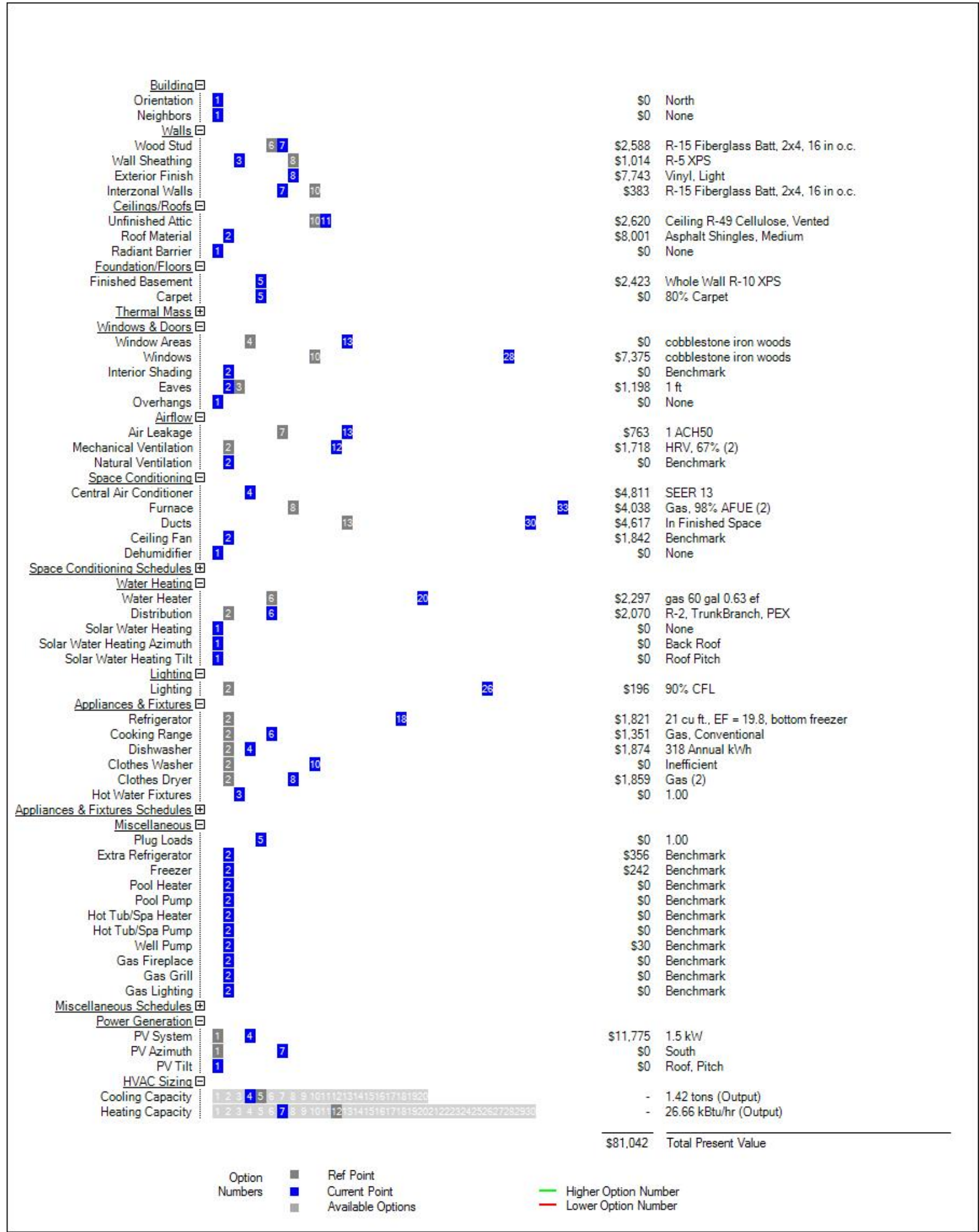




\section{Appendix Q: Morrissey Builders—Lake Elmo, Minnesota, Project Preliminary HERS Reports}

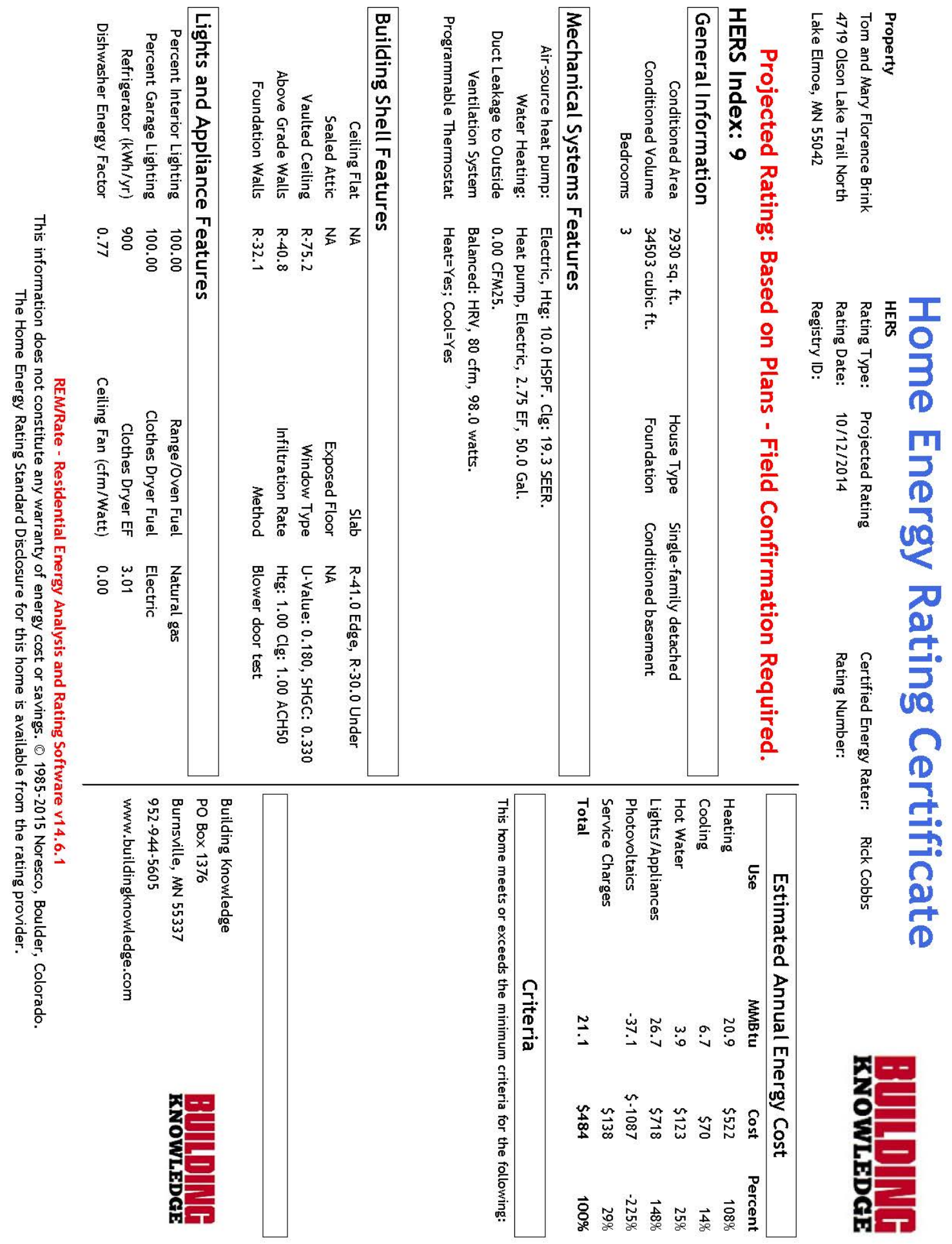




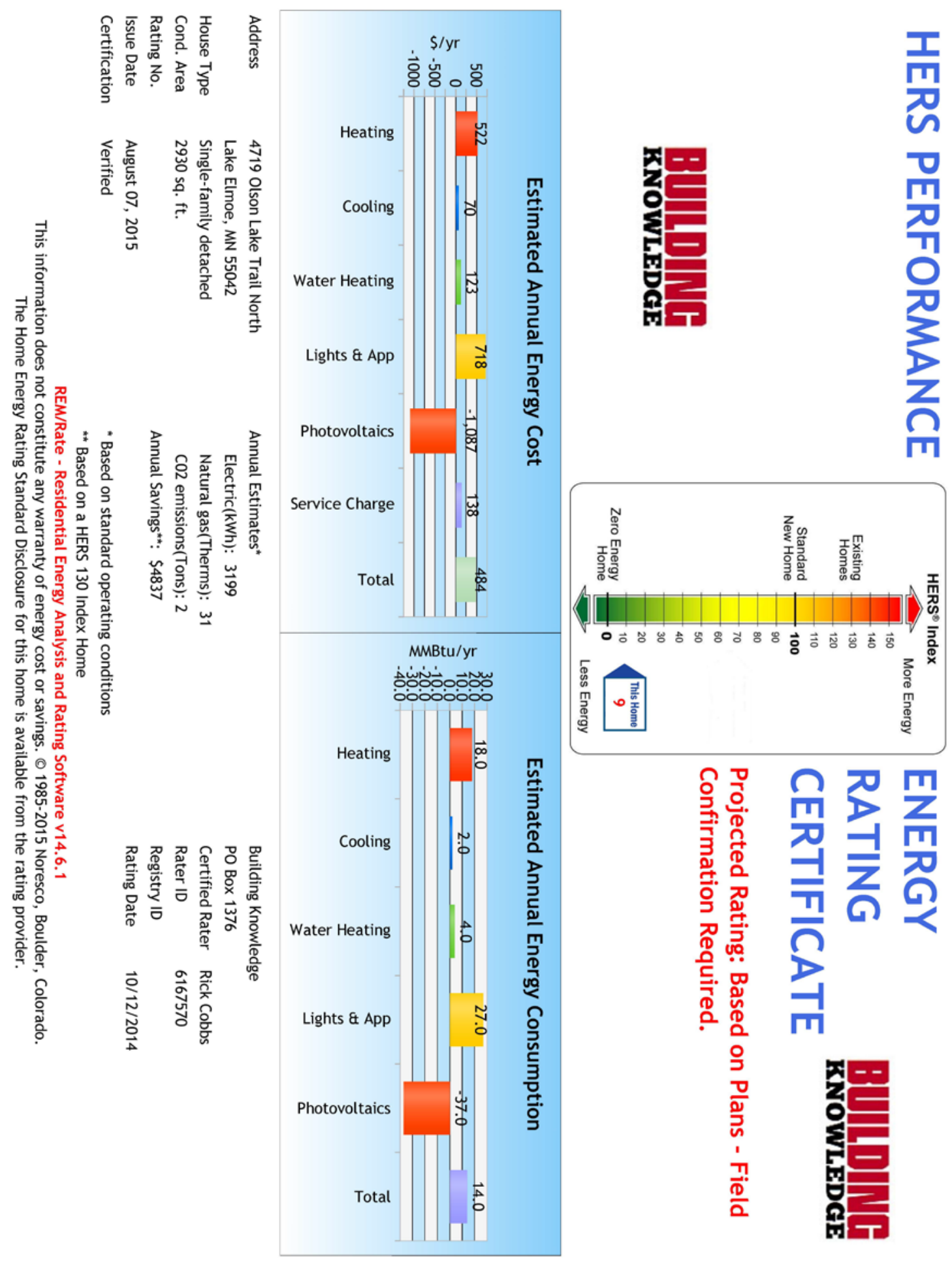




\section{Appendix R: Morrissey Builders—Lake Elmo, Minnesota, Project BEopt Inputs}

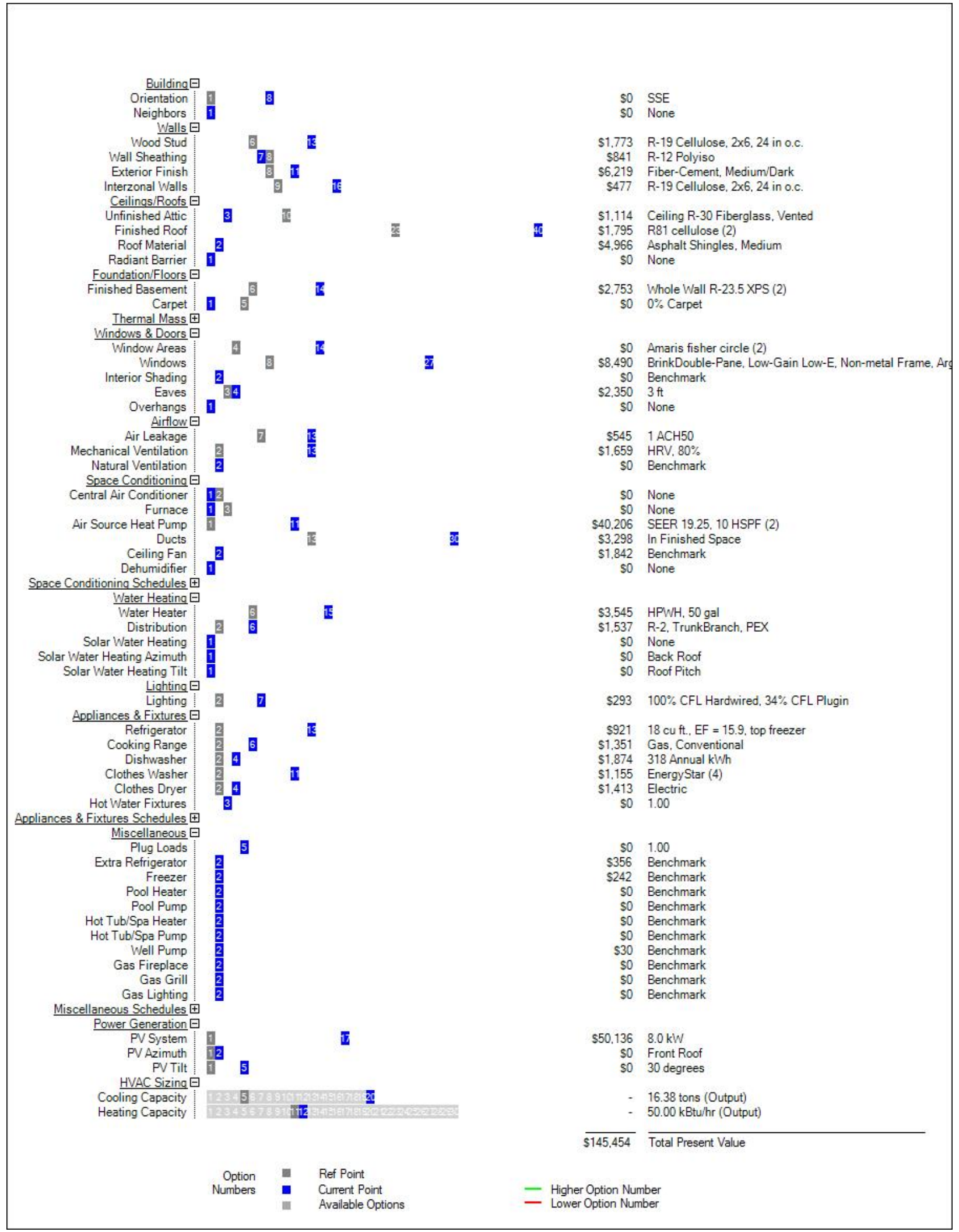




\section{Appendix S: Urban Homeworks-North Minneapolis, Minnesota, Project Preliminary HERS Reports}

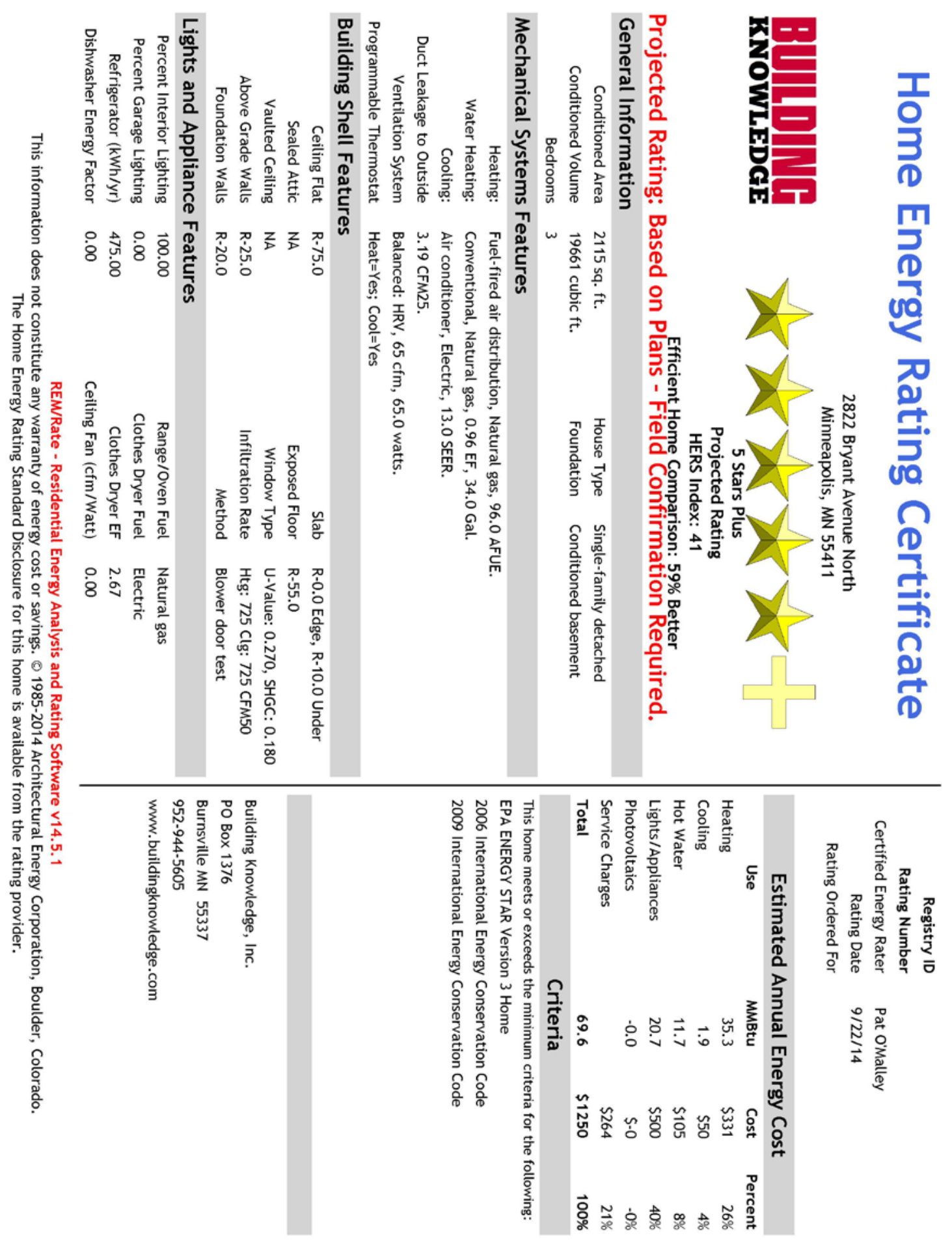




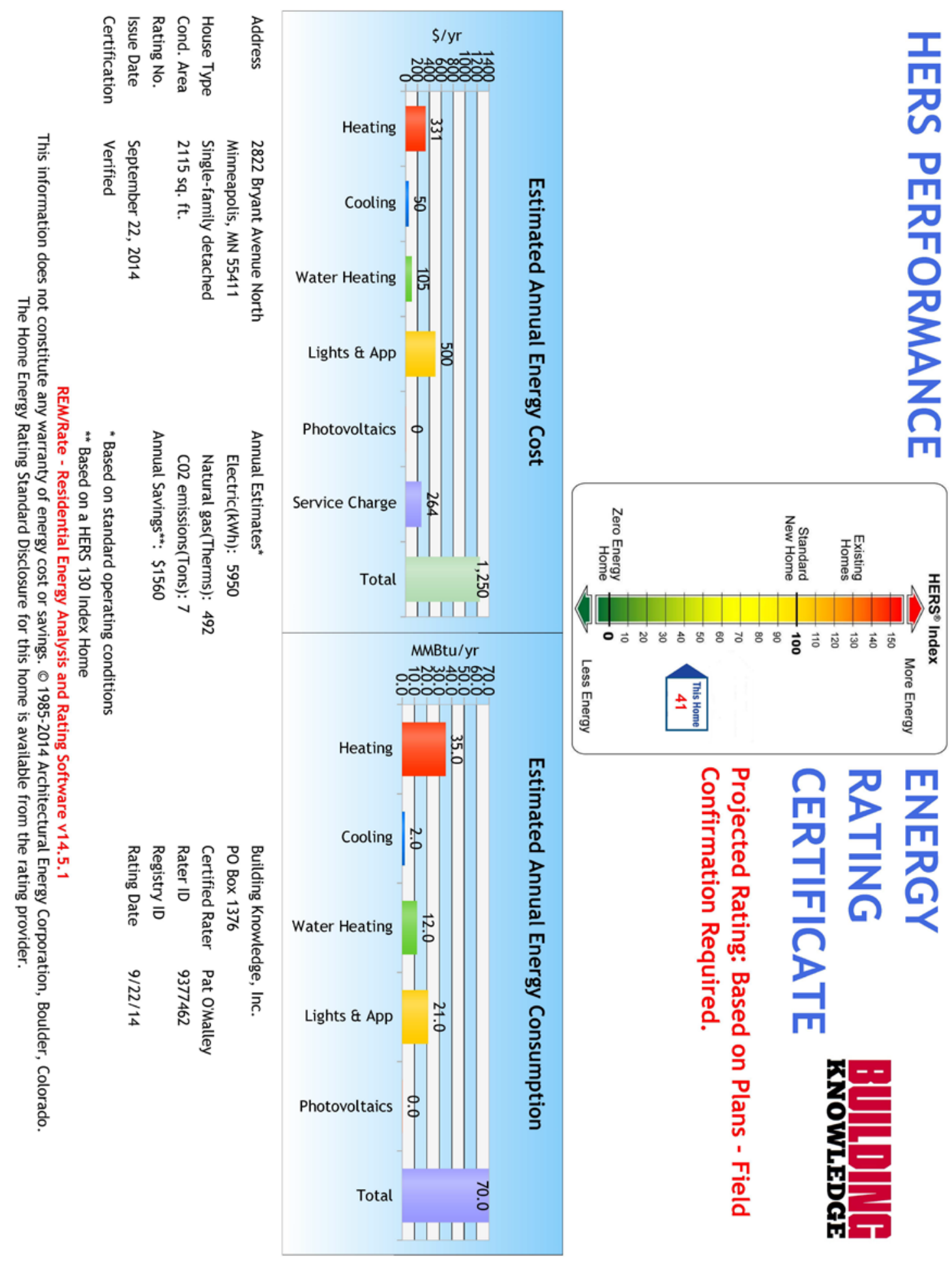




\section{Appendix T: Urban Homeworks-North Minneapolis, Minnesota, Project BEopt Inputs}

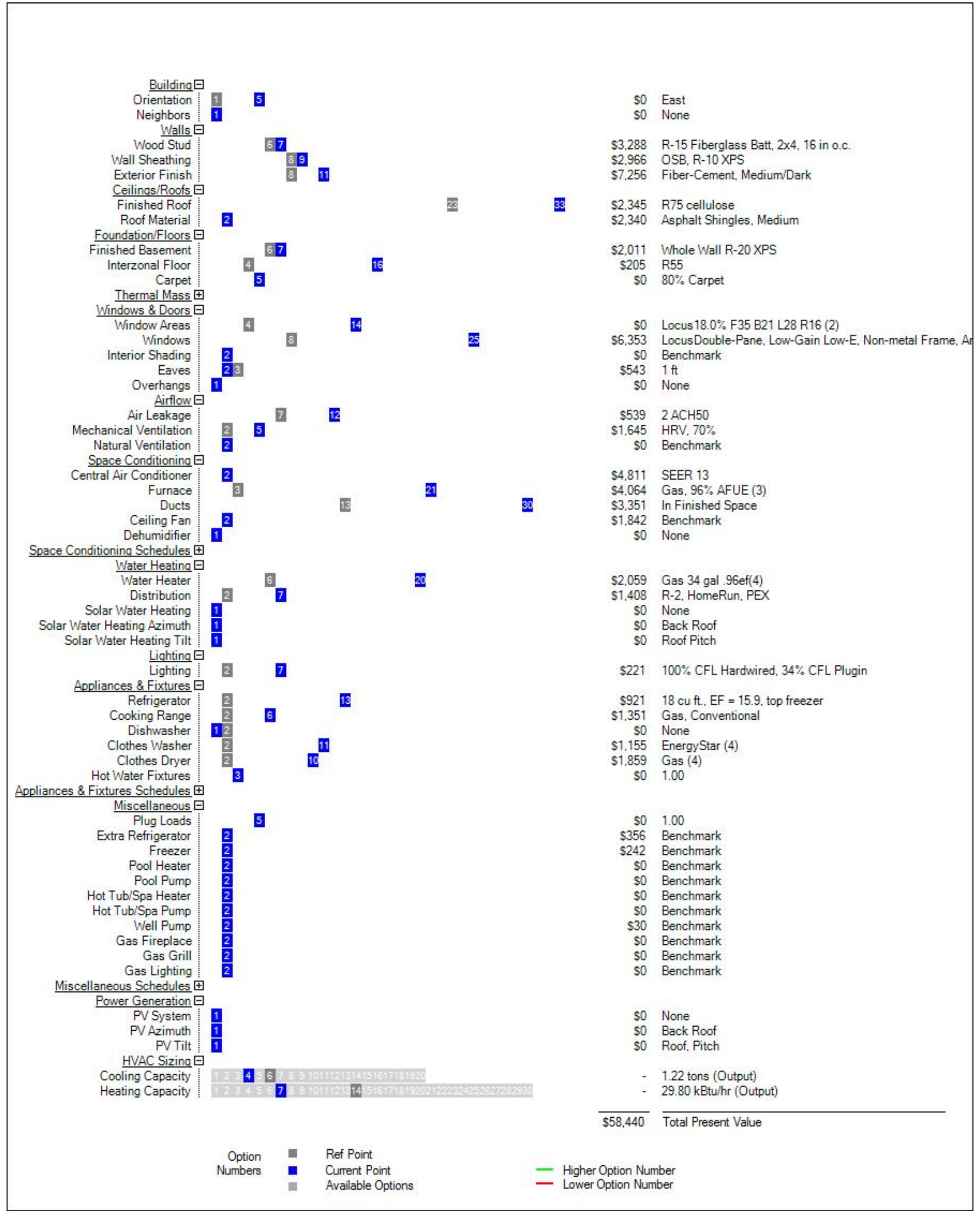

This report is available at no cost from the National Renewable Energy Laboratory (NREL) at www.nrel.gov/publications. 
